Marcelo Corrêa Alves

Engenheiro Agrônomo

\title{
A percepção ambiental de produtores rurais assentados no Estado de São Paulo
}

Orientador:

Prof. Dr. GERD SPAROVEK

Dissertação apresentada para obtenção do título de Mestre em Ecologia de Agroecossistemas

\section{Piracicaba}

2006 
Dados Internacionais de Catalogação na Publicação (CIP) DIVISÃO DE BIBLIOTECA E DOCUMENTAÇÃO - ESALQ/USP

\section{Alves, Marcelo Corrêa}

A percepção ambiental de produtores rurais assentados no Estado de São Paulo /

Marcelo Corrêa Alves. - - Piracicaba, 2006

136 p. : il.

Dissertação (Mestrado) - - Escola Superior de Agricultura Luiz de Queiroz, 2006.

1. Agricultura familiar 2. Assentamento rural 3. Educação ambiental 4. Proteção ambiental 5. Reforma agrária I. Título

CDD 333.31

Permitida a copla totalou parcial deste documento, dosde que ctada a tonte o outor 
Dedicatória

A DEUS, em nome de sua GLÓRIA dedico cada passo de minha vida;

À Luciane, Luma, Marcel e Irene dedico meu amor;

Aos que acreditam na Reforma Agrária como mecanismo de distribuição de dignidade dedico este trabalho. 



\section{Agradecimentos}

Agradeço ao Professor Gerd Sparovek, pela orientação, pela confiança, apoio e valioso conhecimento;

Agradeço a todos os amigos que dedicaram seu tempo para a aplicação e desenvolvimento do questionário: André Assunção, André Reppe, Bruno Ferreira, Cíntia do C. Vilanova, Danilo A. C. Alves, Diana Leb Sasaki, Diléia Santana, Eduardo Pacífico, Érika Andréa Butikofer, Fernando Rabello Paes de Andrade, Fernando Ysenburg, Flávio L. M. de Freitas, Gabriela Nauzi, Israel L. F. Klug, Jane D. Verona, João D. Santes, Júlia Zanim Shimbo, Luciane G. C. Alves, Luiz Edemir Pratti, Manuela Nóbrega Dourado, Mariana Gianotti, Mariana Naomi Tura Oshiro, Marilene Pires Badelucci, Marina, Otacílio dos Santos Santana, Paulo, Pedro Henrique, Rafaela Aparecida da Silva, Sara F. Almeida, Sérgio, Victor Reyes e, especialmente ao amigo Fabrício Anselmo Braga pelo empenho, e pelo comprometimento com as tarefas deste projeto;

Agradeço aos professores que compuseram o Comitê Orientador: Hilton Thadeu Zarate do Couto e Rozely Ferreira dos Santos;

Agradeço aos Professores João Luís Ferreira Batista, Maria Elisa de Paula Eduardo Garavello, Sílvia Maria Guerra Molina, Luiz Antonio Martinelli, Carlos Alberto Vettorazzi.

Agradeço a todos os entrevistados pela acolhida e pela boa conversa. 



\section{Canção para os Fonemas da Alegria}

Peço licença para algumas coisas.

Primeiramente para desfraldar

este canto de amor publicamente.

Sucede que só sei dizer amor

quando reparto o ramo azul de estrelas

que em meu peito floresce de menino.

Peço licença para soletrar,

no alfabeto do sol pernambucano,

a palavra ti-jo-lo, por exemplo,

e poder ver que dentro dela vivem

paredes, aconchegos e janelas,

e descobrir que todos os fonemas

são mágicos sinais que vão se abrindo constelação de girassóis gerando em circulos de amor que de repente estalam como flor no chão de casa.

Ás vezes nem há casa: é só o chão.

Mas sobre o chão quem reina agora é um homem

diferente, que acaba de nascer:

porque unindo pedaços de palavras

aos poucos vai unindo argila e orvalho,

tristeza e pão, cambão e beija-flor,

e acaba por unir a própria vida

no seu peito partida e repartida

quando afinal descobre num clarão

que o mundo é seu também, que o seu trabalho

não é a pena que paga por ser homem,

mas um modo de amar - e de ajudar

o mundo a ser melhor. Peço licença

para avisar que, ao gosto de Jesus,

este homem renascido é um homem novo:

ele atravessa os campos espalhando

a boa-nova, e chama os companheiros

a pelejar no limpo, fronte a fronte,

contra o bicho de quatrocentos anos,

mas cujo fel espesso não resiste

a quarenta horas de total ternura.

Peço licença para terminar

soletrando a canção de rebeldia

que existe em fonemas da alegria:

canção de amor geral que eu vi crescer

nos olhos do homem que aprendeu a ler. 



\section{SUMÁRIO}

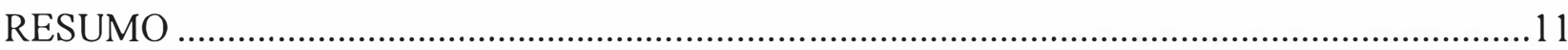

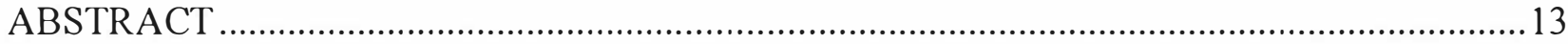

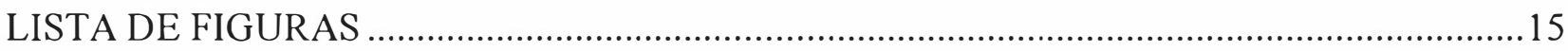

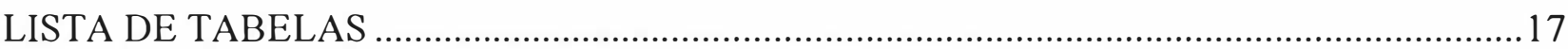

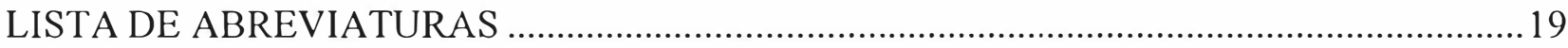

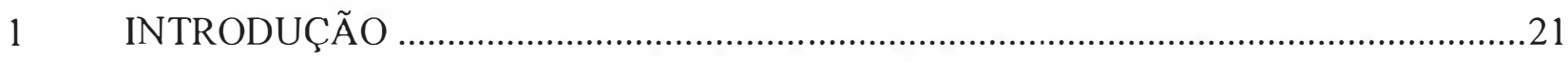

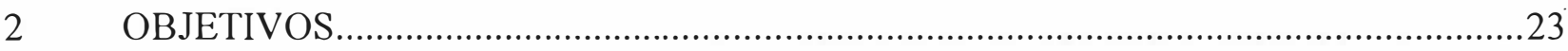

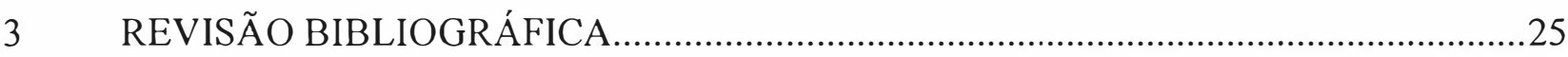

3.1 Conservação, preservação ambiental e sustentabilidade..............................................25

3.2 Posse da terra e preservação ambiental ..................................................................... 33

3.3 Reforma agrária e preservação ambiental ............................................................ 36

3.4 Metodologia para avaliação da percepção .............................................................. 38

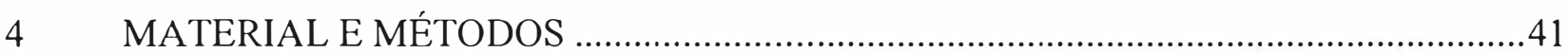

4.1 Aplicação de Questionário para avaliação da percepção ambiental ............................... 41

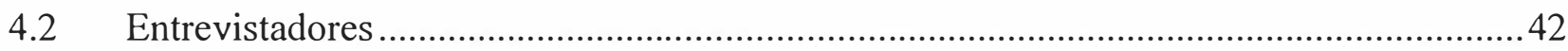

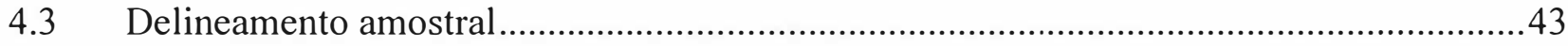

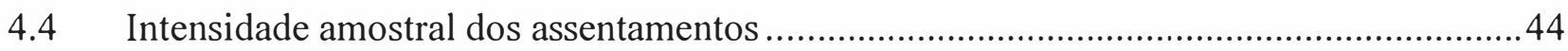

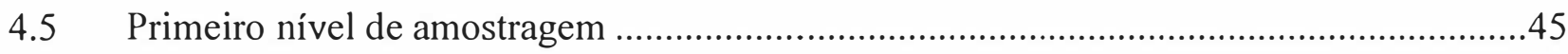

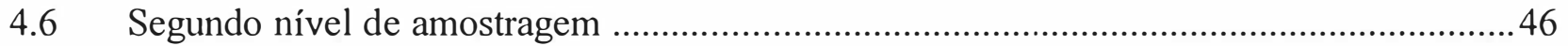

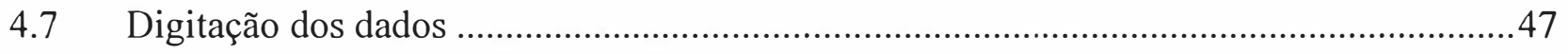

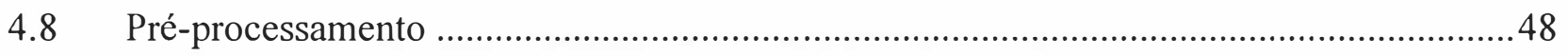

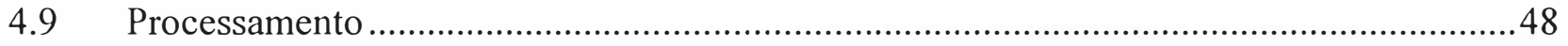

4.9.1 Índice de geral de diversidade do uso da terra (IGD) ............................................49

4.9.2 Índice de Interação com a Mata (IIM) ................................................................50

4.9.3 Índice de percepção de erosão do solo (IES) .......................................................51

4.9.4 Índice de percepção de impacto sobre os recursos florestais (IRF) ..............................55

4.9.5 Índice de percepção do impacto do uso de recursos hídricos (IRH) ..............................53

4.9.6 Índice de percepção de impacto sobre a fauna pela caça (ICA) .....................................5

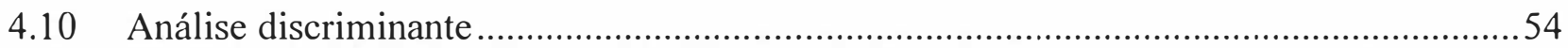

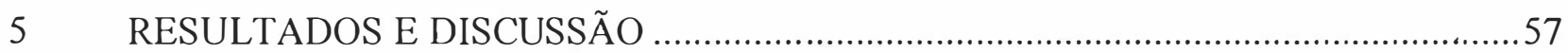




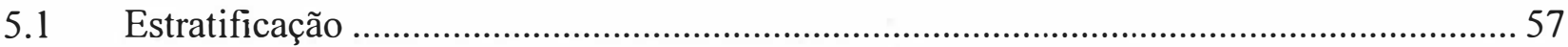

5.2 Número de lotes de cada assentamento ................................................................. 74

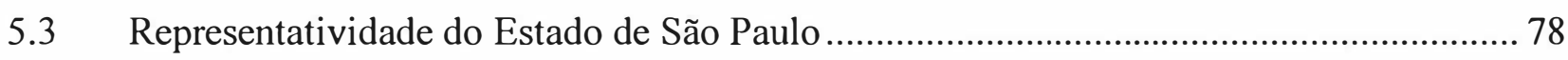

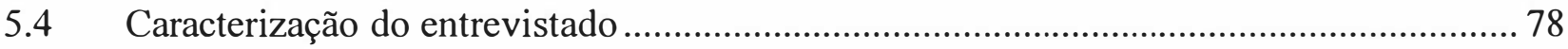

5.4.1 Caracterização do entrevistado quando à titularidade do lote ……………………............ 78

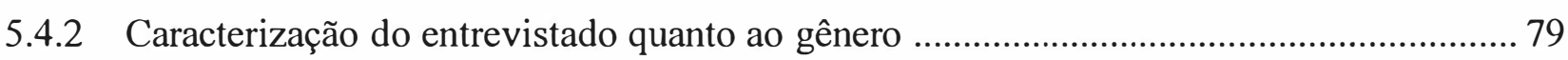

5.4.3 Caracterização do entrevistado quando à escolaridade ....................................................... 80

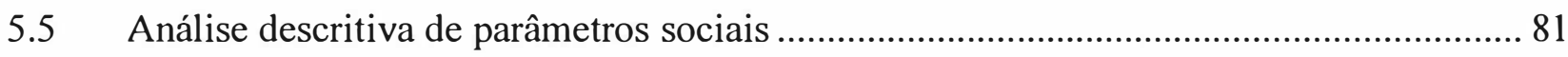

5.5.1 Caracterização do entrevistado quanto à época de chegada à região do

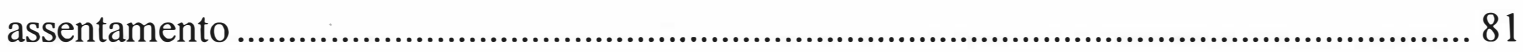

5.5.2 Caracterização lote quanto ao número de moradores ....................................................... 82

5.5.3 Caracterização lote quanto ao número de trabalhadores ..................................................... 83

5.5.4 Caracterização do entrevistado quanto a sua qualidade de vida.......................................... 83

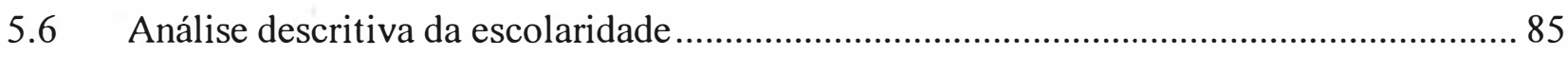

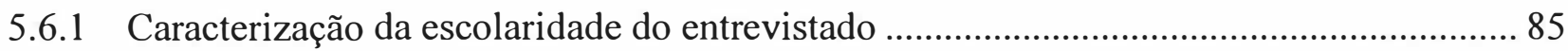

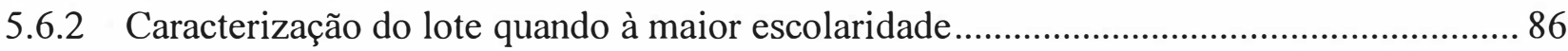

5.6.3 Caracterização da estrutura familiar quando à máxima escolaridade................................. 86

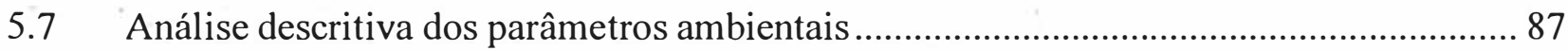

5.7.1 Caracterização da diversidade do uso da terra........................................................... 88

5.7.2 Caracterização da interação com a mata.......................................................................... 90

5.7.3 Caracterização da percepção da erosão do solo................................................................ 92

5.7.4 Caracterização da percepção de impacto sobre os recursos florestais.................................. 92

5.7.5 Caracterização da percepção da caça............................................................................... 94

5.8 Aderência dos parâmetros ambientais aos estratos.......................................................... 95

5.9 Aderência dos parâmetros ambientais às classes educacionais ........................................ 101

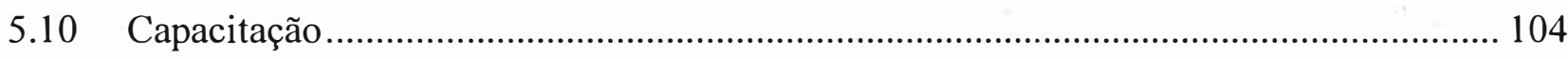

5.11 Estimativas das necessidades de Capacitação e Educação ………………………………... 111

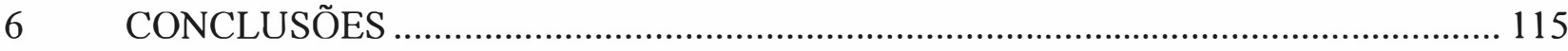

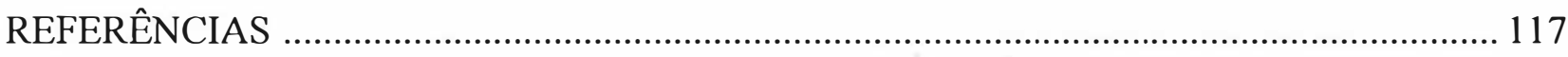

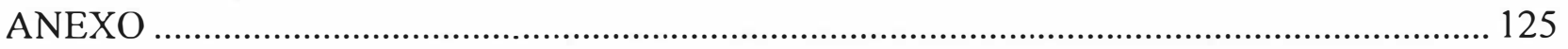


RESUMO

\section{A percepção ambiental de produtores rurais assentados no Estado de São Paulo}

O presente trabalho teve como objetivo avaliar a percepção ambiental dos assentados no Estado de São Paulo através da aplicação de entrevistas apoiadas por questionário semi-estruturado. Foram visitados 50 assentamentos e colhidos depoimentos de 689 assentados, selecionados através de delineamento amostral. Através das respostas foram criados 6 índices de percepção ambiental os quais permitem avaliar a diversidade do uso da terra (IDG), a percepção de erosão (IES), a percepção de impacto sobre os recursos hídricos (IRH) e florestais (IRF), a percepção de caça (ICA) e a interação com a mata (IIM). Medidas sócio-econômicas e educacionais também foram avaliadas tais como a idade, gênero escolaridade, a percepção da qualidade de vida e o número de pessoas que tem moradia e trabalho nos lotes. Foram percebidas diferenças na percepção ambiental e nos índices sócioeconômicos indicando a heterogeneidade dos assentamentos o que impossibilita qualquer conclusão plenamente válida para todo o Estado de São Paulo. Concluiu-se que esta heterogeneidade é fruto da falta de uma diretriz política clara em relação à reforma agrária, o que faz com que critérios técnicos sejam relegados a planos de menor importância no processo de implantação dos assentamentos. Altos graus de capacitação e educação foram observados em $16,98 \pm 3,59 \%$ ao passo que $78,66 \pm 3,59 \%$ se apresentam com niveis educacionais abaixo daquele associado a níveis altos de percepção ambiental. Por fim, apenas 4,36\% $3,59 \%$ se apresentam pouco capacitados, apesar de terem escolaridade suficiente. Em medidas diferentes, educação, capacitação e recursos são necessários e contribuem para a melhoria ambiental.

Palavras-chave: Reforma Agrária; Percepção Ambiental; Educação Ambiental. 



\section{ABSTRACT}

\section{The environmental perception of the rural people settled in the State of São Paulo}

The present work aimed at evaluating the environmental perception of the rural people settled in the State of São Paulo through the application of interviews supplemented by semi-structured questionnaires. Fifty settlements were visited and 689 settled people, selected through sampling outline, were interviewed. Through the answers given, 6 environmental perception indices were created, which allow the evaluation of a diversity of land use (IDG), erosion perception (IES), perception of impact over hydric (IRH) and forest resources (IRF), hunting perception (ICA) and the interaction with the forest (IIM). Social-economical and educational measures such as age, gender, schooling and quality perception of life and the number of people that live and work in the lots were also assessed. In all the situations, differences in the environmental perception and in the social-economical indices were noticed, revealing the heterogeneity of settlements which makes impossible any thoroughly valid conclusion for the entire State of São Paulo. The conclusion is that this heterogeneity is the product of the lack of a clear political rule towards the agrarian reform, which causes the technical criteria to be banished as minor importance plans in the process of implementation of settlements. High capability and educational levels were observed in $16,98 \pm 3,59 \%$ of the people while $78,66 \pm 3,59 \%$ presented lower educational level than that associated with high levels of environmental perception. At last only 4,36 \pm $3,59 \%$ represented to be little capable, although they had enough schooling. In different degrees, education, capability and opportunity are necessary and contribute to environmental improvement.

Key words: Agricultural Reform; Environmental Perception; Environmental Education. 



\section{LISTA DE FIGURAS}

Figura 1 - Mapa de distribuição das capitanias hereditárias, conforme distribuídas

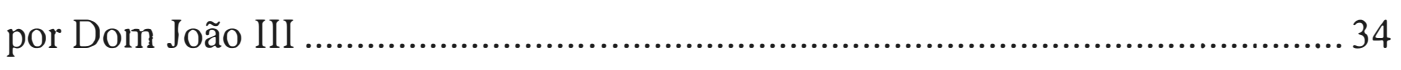

Figura 2 - Reconstituição da cobertura vegetal natural do Estado de São Paulo...................36

Figura 3 - Características médias das medidas ambientais utilizadas na primeira fase da estratificação dos assentamentos do Estado de São Paulo em cada grupo formado.

Figura 4 - Características médias das medidas ambientais utilizadas na primeira fase da estratificação dos assentamentos do Estado de São Paulo em cada grupo formado. 66

Figura 5 - Características médias das medidas ambientais utilizadas na primeira fase da estratificação dos assentamentos do Estado de São Paulo

Figura 6- Efeito dos postos das características na composição dos estratos que

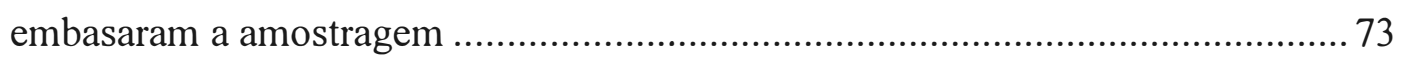

Figura 7 - Qualificação do entrevistado diante da titularidade do lote ............................... 78

Figura 8 - Qualificação do gênero do entrevistado diante da titularidade do lote ................ 79

Figura 9- Qualificação da escolaridade diante do papel de tomador de decisão dentro do lote do assentamento

Figura 10 - Época de chegada à região em relação ao estabelecimento do assentamento e unidade da federação de origem do assentado de

Figura $11-\quad$ Número de moradores no lote ............................................................... 82

Figura 12 - Número de pessoas que trabalham no lote ................................................. 83

Figura 13 - Percepção da qualidade de vida antes, em relação à que tem no assentamento

Figura 14 - Escolaridade do Entrevistado ............................................................... 85

Figura 15 - Maior escolaridade encontrada dentre todos os moradores do lote .................... 86

Figura 16 - Posição na família da pessoa com maior grau de escolaridade............................87

Figura 17 - Índice geral de diversidade do uso da terra .................................................... 88

Figura 18 - Freqüência dos usos da terra nos assentamentos e nos respectivos tipos.............89

Figura 19 - Índice de Interação com a Mata ................................................................ 91

Figura 20 - Índice de percepção de erosão do solo ......................................................... 92 
16

Figura 21 - Índice de percepção de impacto do uso de recursos florestais ...........................93

Figura 22 - Índice de percepção de impacto do uso de recursos hídricos ..............................94

Figura 23 - Índice de percepção de impacto da caça .........................................................95

Figura 24 - Distâncias entre grupos e resultado mais significativos dentre os testes multivariados(Traço de Pilai, Lambda de Wilk, Traço de HotellingLawley e Raiz máxima de Roy) para os estratos.

Figura 25 - Taxas de erro calculadas com base no processo de reclassificação dos dados dos índices de percepção e interação ambiental. A Faixa vermelha representa a probabilidade de erro no caso da classificação aleatória $(93,75 \%)$ 100

Figura 26 - Distâncias entre grupos de escolaridade e resultado mais significativos dentre os testes multivariados(Traço de Pilai, Lambda de Wilk, Traço de Hotelling-Lawley e Raiz máxima de Roy) para os estratos - ns indica distância não significativa no nível de 5\%

Figura 27 - Taxas de erro calculadas com base no processo de reclassificação dos dados dos índices de percepção e interação ambiental. A Faixa vermelha representa a probabilidade de erro no caso da classificação aleatória.

Figura 28 - Dendograma resultante da análise de agrupamento com distância de corte demarcada em 0,8517 , conforme sugerido pela estatística Pseudo$\mathrm{t}^{2}$

Figura 29 - Proporção de assentados em cada grupo formado a partir dos dados de capacitação 107

Figura 30 - Características médias de cada fator de capacitação nos grupos formados 108

Figura 31 - Distâncias entre grupos de capacitação e resultado mais significativos dentre os testes multivariados(Traço de Pilai, Lambda de Wilk, Traço de Hotelling-Lawley e Raiz máxima de Roy) para os estratos - ns indica distância não significativa no nível de $5 \%$

Figura 32 - Taxas de erro calculadas com base no processo de reclassificação dos dados dos índices de percepção e interação ambiental. A Faixa vermelha representa a probabilidade de erro no caso da classificação aleatória 


\section{LISTA DE TABELAS}

Tabela 1 Nomes dos projetos de assentamento do Estado de São Paulo em abril de 2005

Tabela 2 - Projetos de assentamento implantados após o levantamento de dados conduzido em 2002 para estudo da qualidade dos assentamentos da reforma agrária brasileira

Tabela 3 - Projetos de assentamento não usados no processo de estratificação e amostragem

Tabela 4 - Identificação das questões formuladas, temas abordados e campos para registro em software para armazenamento de dados usadas na análise de agrupamento, base para a estratificação dos assentamentos do Estado de São Paulo

Tabela 5 Assentamentos agrupados no primeiro estágio da estratificação em função da uniformidade das medidas ambientais avaliadas através de Cluster Analisys usando o método average

Tabela 6- Assentamentos agrupados no segundo estágio da estratificação em função da uniformidade das medidas ambientais avaliadas através de Cluster Analisys usando o método average

Tabela 7 - Assentamentos agrupados no terceiro estágio da estratificação. 68

Tabela 8- Contabilidade da aplicação de questionários de acordo com o delineamento amostral. Tamanho da amostra calculado para intervalo de confiança de 20\%, nível de significância de 5\% e o tamanho da população é o número de lotes de cada assentamento

Tabela 9 - Assentamentos não selecionados preliminarmente e que participaram do projeto de pesquisa

Tabela 10 - Contabilidade do número de questionários planejados e efetivamente aplicados dentro dos estratos.

Tabela 11 - Resultado do processo de seleção de variáveis discriminantes para variável classificatória estrato amostral 
18

Tabela 12 - Teste de normalidade univariada de Shapiro-Wilk e testes de Mardia e de Henze-Zirkler para multinormalidade dos índices IRF, IRH, IIM,

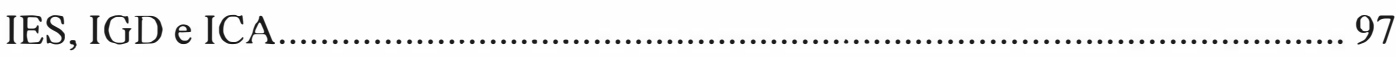

Tabela 13 - Resultado do processo de seleção de variáveis discriminantes para variável classificatória grupo educacional ................................................... 101

Tabela 14 - Teste de normalidade univariada de Shapiro-Wilk e testes de Mardia e de Henze-Zirkler para multinormalidade dos índices IRF, IRH, IES................. 101

Tabela 15 - Características do processo de agrupamento nos últimos 8 níveis com objetivo de selecionar o ponto de corte apropriado através da estatística Pseudo- $\mathrm{t}^{2}$ 106

Tabela 16 - Resultado do processo de seleção de variáveis discriminantes para variável classificatória Grupo de Capacitação

Tabela 17 - Teste de normalidade univariada de Shapiro-Wilk e testes de Mardia e de Henze-Zirkler para multinormalidade dos índices IRF, IRH, IES

Tabela 18 - Proporção de assentados nos diversos estratos de capacitação e educação. 112 


\title{
LISTA DE ABREVIATURAS
}

\author{
APP - Área de Preservação Permanente \\ CONAMA - Conselho Nacional do Meio Ambiente \\ ICA - Índice de Caça \\ IDG - Índice de Diversidade Geral \\ IES - Índice de Erosão do Solo \\ IIM - Índice de Interação com a Mata \\ IRF - Índice de Recursos Florestais \\ IRH - Índice de Recursos Hídricos \\ ITESP - Fundação Instituto de Terras do Estado de São Paulo "José Gomes da Silva" \\ PA - Projeto de Assentamento \\ PEA - População Economicamente Ativa \\ RL - Reserva Legal \\ WWF - World Wildlife Fund
}





\section{INTRODUÇÃO}

"Concordaríamos e renunciaríamos a ver resolvidos dogmaticamente nossos problemas, se compreendêssemos antecipadamente que, seja qual for a resposta, esta só aumentaria nossa ignorância e nos precipitaria de uma incompreensibilidade numa outra e de uma obscuridade noutra maior ainda..."

KANT

Admitindo que o estágio de comprometimento com a atitude conservacionista é influenciada pela educação, pela capacitação e pela disponibilidade de recursos financeiros do produtor rural, o presente trabalho objetiva caracterizar os produtores rurais assentados no Estado de São Paulo quanto à sua percepção ambiental. Com isto, pretende-se fornecer subsídios para a instalação de ações públicas ou privadas, bem como o desenvolvimento de indicadores que permitam reconhecer qual ação é mais adequada no contexto da reforma agrária brasileira.

A ausência de percepção de problemas remete para políticas educacionais uma vez que somente o processo educativo permitirá a construção de um mapa cognitivo no qual a percepção da importância do ambiente natural preservado ou reconstituído terá espaço.

Em um outro patamar situam-se os produtores rurais que têm consciência da importância da preservação elou conservação, mas que não apresentam capacitação para implementar medidas práticas tais como: reflorestamento, preservação ambiental, aproveitamento sustentado dos recursos naturais, medidas de combate à erosão e destinação de resíduos, entre outros. Neste caso, a capacitação é um atalho, pois envolve treinamentos de curta duração nos quais há menores investimentos. Por fim, para os que apresentam percepção e capacidade resta a necessidade de se disponibilizar recursos na forma de financiamento, incentivo, desconto, material entre outros fatores que possibilitem a efetiva implementação das medidas conservacionistas. 



\section{OBJETIVOS}

"A falta de cuidado no trato da natureza e dos recursos escassos, a ausência de cuidado com referência ao poder da tecnociência que construiu armas de destruição em massa e de devastação da biosfera e da própria sobrevivência da espécie humana nos está levando a um impasse sem precedentes. Ou cuidamos ou pereceremos".

Leonardo Boff

Partindo-se do princípio de que as percepções dos indivíduos, seus processos cognitivos e seus valores afetam diretamente a estrutura da paisagem e por ela são afetadas (NASSAUER 1995, citado por DIEDERICHSEN, 2003); também a atitude conservacionista pode ser influenciada pelas percepções dos indivíduos, tanto que a atitude conservacionista foi considerada como o resultado da articulação de três registros ecológicos: meio ambiente físico, relações sociais e subjetividade humana o que foi batizado de "ecosofia" (GUATTARI, 1990).

Assumidos estes três registros como determinantes da interpretação do ambiente natural pelas pessoas e conseqüentemente, no grau de comprometimento com a conservação ambiental, objetiva-se neste trabalho a quantificação do estágio de percepção dos produtores rurais. De acordo com o grau de percepção, a aplicação de ações específicas pode resultar na maior eficiência do emprego dos recursos disponíveis e a criação de serviços ambientais nas áreas reformadas.

A meta mais importante deste estudo é a dissociação de situações que requerem:

a) Medidas de cunho educativo.

b) Medidas que propiciem a capacitação dos assentados na implantação e condução de processos de melhoria ambiental.

c) Medidas que tornem disponíveis recursos necessários para implantação de projetos de melhoria ambiental pelos assentados. 
Parte-se da premissa de que para produtores rurais que não percebam a importância da preservação e conservação da natureza, medidas de cunho educativo são necessárias já que disto dependerá a instalação de uma atitude conservacionista permanente e expontânea.

Se o produtor já é dono de uma educação que sustenta uma atitude conservacionista, um outro tipo de ação pode ser necessário: o de capacitação. Uma vez conhecedor da importância da atitude conservacionista, a capacitação permitirá que o produtor implemente ações de forma correta e eficiente.

Uma terceira paisagem que se vislumbra neste cenário é a do produtor educado e capacitado. Ou seja, consciente dos benefícios decorrentes da preservação ambiental e capacitado para implementar medidas que mitiguem o efeito do uso da terra sobre o ambiente natural. Neste caso, resta apenas a necessidade de que sejam disponibilizados recursos financeiros para que medidas conservacionistas sejam implementadas.

O estudo se restringirá aos assentamentos rurais estabelecidos com finalidade de reforma agrária no Estado de São Paulo, para que se tenha o foco necessário em resultados conclusivos. Abranger outros tipos de propriedades agrícolas poderia conduzir a uma gama ampla de realidades que dificultariam a obtenção de conclusões embasadas e suficientemente densas, como desejado em qualquer texto científico.

É importante que se considere que a implantação de um projeto de reforma agrária deve ser totalmente coerente com o restabelecimento da função social da terra o que também implica na necessidade de conservação dos recursos naturais, conforme determinado pela Constituição Federal.

O respeito à legislação e a manutenção de serviços ambientais relevantes nas áreas reformadas legitima o investimento público e a intervenção do Estado no processo.

Testar a assunção da existência dos três estágios cognitivos previamente descritos assim como a quantificação dos produtores rurais assentados no Estado de São Paulo que se enquadram em cada um destes estágios é o objetivo principal deste trabalho e que, para isto, depende do estabelecimento de indicadores que reflitam adequadamente a percepção ambiental; da retratação da realidade dos assentados dos pontos de vista educacional e de capacitação para a condução de processos de melhoria ambiental. 
3 REVISÃO BIBLIOGRÁFICA

"Se é normal a condição doentia do homem - e não há como contestar essa normalidade -, tanto mais deveriam ser reverenciados os casos raros de pujança da alma e do corpo, acasos felizes do homem, tanto mais deveriam ser os bens logrados protegidos do ar ruim, do ar de doentes. Isto é feito?"

NIETZSCHE

\subsection{Conservação, preservação ambiental e sustentabilidade.}

A partir da década de 70 se iniciou um período de pressão ambientalista que fortaleceu as idéias de conservação e preservação ambiental e culminaram com a criação de mecanismos de controle do impacto ambiental na aprovação de projetos, na fiscalização de sua execução e na operação (TUCCI, 2004).

Corroborando a alocação temporal para as preocupações com o meio ambiente podem ser citadas as datas de fundação do World Wildlife Fund (WWF): 11 de setembro de $1961^{1}$ que hoje congrega aproximadamente 5 milhões de associados e do Greenpeace, fundado em $1971^{2}$.

A pressão ambientalista contribuiu para modificar a visão do Progresso que no final do século XIX era visto como um Promotor de Riqueza e ao Final século XX, como causador de impactos ambientais (BURSZTYN, 2001).

Neste período, nos países industrializados, o investimento começa a mudar de prioridade, dando ênfase à conservação e à preservação ambiental. Nos países subdesenvolvidos, a opinião pública dos países desenvolvidos pode ser sentida a partir de pressões sobre os bancos de fomento e desenvolvimento que acabaram por inibir investimentos em países que não adotaram práticas conservacionistas, principalmente na área de recursos hídricos (TUCCI, 2004).

Com isto, se acentua a responsabilidade do modelo econômico vigente na geração de miséria nos países subdesenvolvidos. Um dos primeiros economistas a lançar este alerta foi o

\footnotetext{
${ }^{1}$ http://panda.org/about wwf/who we are/history/sixties.cfm - 28/01/2005

2 http://www.greenpeace.org/international en/history - 28/01/2005
} 
sueco Gunnar Myrdal (Prêmio Nobel de Economia de 1974), que chamou a atenção para o "ciclo vicioso da pobreza", que se produzia como corolário do padrão de crescimento econômico vigente (BARTHOLO JÚNIOR; BURSZTYN, 2001).

Ainda no final do século XX, inicia-se o processo de conscientização da insustentabilidade do estilo de desenvolvimento das nações ricas e da impossibilidade de sua universalização o que faz com que surja uma idéia que progressivamente mobiliza as nações: o desenvolvimento sustentável. Um novo estilo de desenvolvimento que tem como meta a busca da sustentabilidade social e humana capaz de ser solidária com a biosfera. (VIOTTI, 2001).

O princípio de insustentabilidade foi percebido bem antes, com base nas taxas de crescimento populacional e, as relativamente menores taxas de crescimento da capacidade de produção de alimentos o que exigiria medidas de controle que conteriam o crescimento da população humana (MALTHUS, 1826). Num primeiro momento, doenças, catástrofes e guerras surgiam como alternativa à inviabilidade de suporte à vida de uma população humana crescente em taxas maiores que o crescimento da produção de alimentos. Embora não tenham sido plenamente confirmada, por força de inovações tecnológicas, ficou cunhado o termo insustentabilidade que, novamente, toma lugar nas discussões políticas e científicas em face, talvez, da necessidade de uma nova forma de relacionamento da humanidade com a biosfera.

O princípio de sustentabilidade nasce de uma proposta que tem em seu horizonte uma modernidade ética, não apenas uma modernidade técnica. O princípio "sustentabilidade" implica incorporar ao horizonte da intervenção transformadora do "mundo da necessidade", o compromisso com a perenização da vida (BARTHOLO JÚNIOR; BURSZTYN, 2001).

Não faltam termos para especificar alternativos significados do termo sustentável (MITLIN, 1992; PEZZY, 1992; REDCLIF, 1992, apud MEADOWCROFT, 1999). Além disto, o termo sustentável ou seu correlato sustentabilidade pode ser combinado com uma vasta gama de outros termos tais como: desenvolvimento e assim são criados os termos: crescimento sustentável, biosfera sustentável, vida sustentável, gerenciamento de recursos sustentado, cidades sustentáveis, ecossistemas sustentáveis, sustentabilidade cultural e assim por diante. Esta proliferação de termos ilustra a fluidez das categorias conceituais e reflete a complexidade do termo (MEADOWCROFT, 1999). 
O chamado desenvolvimento sustentável é geralmente definido como o desenvolvimento que atende às carências do presente, sem prejudicar a capacidade das gerações futuras de satisfazer suas próprias necessidades (HENDERSON, 2004).

Já o termo sustentabilidade ambiental é uma expressão mais ambígua. Em geral, seu uso tem significado entre dois pólos: de um lado há uma sugestão de que o termo se refere à sustentabilidade do ambiente natural, de outro lado é associado com a dimensão da sustentabilidade de instituições e práticas sociais. No primeiro caso, se refere à preservação dos sistemas e processos naturais e no segundo caso, o que devem ser sustentados são práticas e instituições sociais e o ambiente é o limitante para isto (MEADOWCROFT, 1999).

De qualquer forma, o desenvolvimento sustentável de HENDERSON (2004) se associa com a sustentabilidade ambiental e ao segundo significado de MEADOWCROFT (1999) já que o desenvolvimento que se sugere é o desenvolvimento do homem que estabelece suas práticas e instituições sociais, as quais devem ser sustentados pelo ambiente. A inovação da sustentabilidade inclui a necessidade de que seja possível a explotação até limites de tempo e espaço que permitam a recomposição ambiental, para que se garanta que novas populações possam, permanentemente, contar com os recursos necessários para sua sobrevivência.

Longe de algo utópico, entretanto, encontra-se em andamento, o processo de transição das sociedades industriais, em busca da sustentabilidade ecológica e social. Fazem parte de todos os movimentos de troca de paradigmas fenômenos como dissonância cognitiva e confusão a respeito de definições, critérios, decisões políticas e econômicas, para não mencionar itens que envolvem assuntos morais e culturais (HENDERSON, 2004).

Uma outra controvérsia surge do diálogo de economistas e ambientalistas que divergem sobre o tema de como prevenir a destruição da natureza. Ambientalistas sustentam que os preços de mercado não consideram importantes impactos ambientais e que o governo deve proteger o ambiente como bem público através de padrões e limitações. Por outro lado, os economistas ambientais atribuem ao mercado a capacidade de considerar fatores ambientais, até então, ignorados (BARTELMUS, 2002).

Ao se orientar em custos, dois fatores despontam como importantes: o gerenciamento das informações e da energia; duas tecnologias fundamentais do desenvolvimento social humano. 


\section{8}

Ambas precisam, doravante, ser dimensionadas em termos da sustentabilidade ecológica e social (que exige eqüidade e justiça, tanto quanto eficiência). Terão de ser estabelecidos novos parâmetros de desempenho, cruciais para a boa condução de nossas sociedades com destino à sustentabilidade, não mais tendo por base o PIB ou PNB, nem outras medidas macroeconômicas de riqueza e progresso que ora avaliam as áreas de eficiência energética, educação, saúde, infraestrutura e outros setores sociais (HENDERSON, 2004).

A maior parte dos ambientalistas refutam a transformação do ambiente em bens negociáveis. Em seu ponto de vista a negociação dos bens ambientais é uma forma de colonização uma vez que o valor monetário distorce o real valor do ambiente e seu significado para a qualidade de vida da presente e das futuras gerações. Já os ambientalistas economistas têm uma visão diferente da natureza: eles consideram as perdas de recursos naturais e as capacidades de absorção de poluentes, como coisas e funções raras e como todo produto ou função rara, serão disputadas pelos homens, sejam comercializadas em mercados, ou não (BARTELMUS, 2002).

É neste contexto, que se reflete sobre a validade da implementação de medidas as quais modifiquem o ambiente natural para o uso da terra com finalidades agrícolas. Dentre as atividades humanas que pressionam áreas naturais, a agricultura se destaca pela necessidade de espaço físico, pelo grande consumo de água e pelo uso de defensivos.

O uso da terra é, portanto, um concorrente direto da preservação ambiental e a viabilidade da preservação ambiental depende, no ponto de vista dos ambientalistas economistas, do valor gerado pelo uso em contraste com o valor da área preservada. Esta é a realidade observada no passado quando atividades econômicas lucrativas justificaram a devastação de amplas áreas de floresta em todas as partes do mundo. Neste contexto, a preservação ambiental passa a ter significado em função da raridade das áreas naturais, as quais passam a ter valores maiores os quais justificam sua manutenção no estado atual, ou até a recuperação em função do aumento do valor intrínseco da área, após a recuperação.

Entre os países mais desenvolvidos, a economia rural se depara com complexas combinações que ameaçam a sustentabilidade. Algumas destas ameaças, decorrentes de práticas que historicamente se aplicam na agricultura, atingem a comunidade rural como um todo: a diminuição da qualidade do solo, decorrente do uso de defensivos têm contribuído para a redução 
da fertilidade e o aumento do risco de erosão. O impacto desta tendência é reduzir a capacidade de produção vegetal em certas áreas e acelerar a poluição, sobretudo da água (KING, 2002).

A sustentabilidade da produção agrícola e de seus agroecossistemas depende da habilidade dos produtores rurais de superar as ameaças atuais e futuras e continuar seus empreendimentos (NOORDWIJK, 2001). O maior desafio a ser vencido é a perda de produtividade e o fator que mais restringe o crescimento vegetal é a falta de nutrientes no solo, porém, não decorrente da falta de conhecimento sobre nutrição vegetal, já que fertilizantes são utilizados desde que sejam financeiramente interessantes para os produtores (NOORDWIJK, 2001). Com base nisto, pode-se concluir que o uso da terra pode ser feito de forma sustentável, desde que sejam implementadas medidas de proteção biológica que impeçam danos ao ambiente adjacente à área produtiva e se cuide da reposição do que é exportado pelas produções (NOORDWIJK, 2001).

Além dos fatores anteriormente citados, a extinção genética decorrente da monocultura tem feito a agricultura menos adaptável e mais vulnerável a doenças, o declínio da qualidade da água e a presença toxinas no ambiente, gerados pelo acréscimo do uso de pesticidas e fertilizantes desde a segunda grande guerra mundial têm causado danos à flora, à fauna e à qualidade do ar, deve-se atentar para o fato de que: todos esses prejuízos e atividades potencialmente perigosas têm sido feitas com a aprovação de autoridades governamentais nacionais (KING, 2002).

Evidentemente que a permissividade que conduziu aos prejuízos previamente listados tem origem em motivos que suplantam o poder político do governo e que impedem uma ação voltada para a sustentabilidade.

São perceptíveis pressões que ainda hoje determinam a forma de se gerenciar a indústria da agricultura: o direcionamento para o aumento da produtividade no mundo desenvolvido; a pequena tolerância do mercado consumidor por variedades "não comerciais" que, por exemplo: levaram à extinção de aproximadamente 6000 tipos de maçãs desde o século 19; o crescimento de grandes propriedades rurais e corporações agrícolas em detrimento dos pequenos e médios empreendimentos; as mudanças do clima global que têm aumentado a dificuldade de se prever os níveis de chuva (KING, 2002). 
Após tudo isto e cientes do potencial rompimento dos limites da capacidade de suporte à vida do meio ambiente a continuação do uso da terra é uma necessidade da humanidade, tanto para os países menos como para os países mais desenvolvidos.

O objetivo central do modelo desenvolvido nas décadas de 60 e 70 foi garantir a estabilidade no fornecimento interno de alimento, permitindo o processo de urbanização da economia brasileira, mas não gerando altas taxas de inflação (DIAS; BARROS, 2003).

Há quase 60 anos, com a promissora emergência de idéias, movimentos e estatutos que se seguiram a Segunda Guerra Mundial, a luta contra a fome e a concepção de um estado de segurança alimentar e bem-estar nutricional passaram a figurar como grandes desafios no ideário das sociedades civis e na agenda dos poderes públicos. Assinala-se hoje um movimento no sentido de praticar a segurança alimentar como um referencial obrigatório dos direitos de cidadania. É o que está estabelecido no Pacto Internacional dos Direitos Econômicos, Sociais e Culturais (BATISTA FILHO, 2004).

No pós-guerra, o brasileiro Josué de Castro impactou o mundo com seus livros "Geografia da Fome" e "Geopolítica da Fome"; decisivos para a consolidação de um movimento internacional para a segurança alimentar: o Fundo das Nações Unidas para a Agricultura e Alimentação. No Brasil, se refletiram na instituição do salário mínimo, que estabeleceu uma cesta de 12 alimentos, que comprometeria $50 \%$ da estimativa salarial e atenderia $100 \%$ das recomendações de calorias, proteínas, sais minerais e vitaminas (BATISTA FILHO, 2004).

Enquanto que dados confiáveis não são disponíveis, a distribuição de riquezas no Brasil é seguramente mais desigual que a distribuição de rendas o que fica claroro caso da propriedade da terra, a mais tradicional forma de riqueza, senão a forma mais dominante. A pobreza é duas vezes maior no campo que nas cidades e os agricultores e trabalhadores rurais são o maior grupo entre os pobres. Seu assentamento para ocupação de áreas vazias (colonização) ou a redistribuição de terra improdutiva têm se repetido na política brasileira por gerações (GORDON, 2001).

Apesar dos antecedentes, o Brasil não tem cumprido uma trajetória correta nessa área, já que poderiam ser ofertadas mais de 3000 calorias por habitante por dia, bem acima das necessidades estimadas de 2.200 calorias, todavia, observam-se sérias vulnerabilidades na cadeia 
armazenagem-comercialização-consumo e, sobretudo, no elo terminal do ciclo, isto é, na instância da utilização biológica, face ao perfil de co-morbidades que interagem com o estado nutricional. Como reflexo desse quadro, cerca de 10\% de nossas crianças apresentam déficit de altura, e entre 15 e $30 \%$, deficiência de vitamina A. A anemia afeta $20 \%$ dos escolares, 30 a $40 \%$ das gestantes e entre 40 e 50\% das crianças de 6-60 meses, tornando-se o problema de carência com maior magnitude no país. Paradoxalmente, a obesidade cresce em escala epidêmica, praticamente tendo triplicado entre homens e mulheres adultos no último quarto do século XX (BATISTA FILHO, 2004).

A citação é indicativa de que não somente se necessita da produção de alimentos para que se garanta a segurança alimentar, mas que também são pertinentes esforços em direção da educação e da capacitação que conduzam a um melhor aproveitamento da produção de alimentos pois: "A saída para este país não é cidadania não, é educação. Porque educação vai gerar cidadania. É a pessoa ser inteira, ser dona do nariz dela, ter a vontade dela" (membro do Comitê Caixa de Assistência dos Advogados do Estado do Rio de Janeiro/ Andaraí) (MAGALHÃES, 2002).

A partir de dados da Pesquisa sobre Padrões de Vida implementada pelo Instituto Brasileiro de Geografia e Estatística foi observado que a renda anual per capita dos habitantes da zona rural nas regiões nordeste e sudeste foram de $R \$ 2.123,00$ e $R \$ 3.056,00$; respectivamente (DIAS; BARROS, 2003).

Apesar das médias relativamente altas, há que se considerar que o índice de Gini para as duas regiões se situa em 0,63 o que indica um grande grau de dissimilaridade o que acaba por revelar que $50 \%$ das pessoas da região nordeste e $24,6 \%$ da população rural do sudeste vivem abaixo da linha de pobreza extrema (igual ao mínimo necessário para o suprimento básico de alimentos), que é igual a R \$781,00 per capita anualmente (DIAS; BARROS, 2003).

Se considerada a linha de pobreza (aproximadamente o dobro da linha de pobreza extrema), não menos que $82 \%$ e $65 \%$ da população rural no nordeste e no sudeste, respectivamente, é pobre (DIAS; BARROS, 2003). 45\% da população de todo o Brasil é pobre (FERREIRA; LANJOU; NERI, 1999). 
Estranhamente, apesar da pobreza denotada nos índices, nas décadas de 70 e 80 o cenário brasileiro aponta para um aumento nos ganhos de produtividade o que afeta a agricultura familiar de maneira a reduzir a absorção de mão-de-obra. O ajuste do setor, promovido através do aumento da produtividade, alicerçou o crescimento sustentado da agricultura do período, porém com a expansão do desemprego rural e alteração da estrutura das empresas agrícolas.

Foi detectada, também, a modificação da empregabilidade do habitante da zona rural que passou a ter, com maior freqüência, empregos principais na zona urbana (DIAS; BARROS, 2003).

A safra agrícola de 1995/96 foi a que recebeu o menor volume de crédito rural no Brasil desde o final dos anos sessenta. O valor total dos financiamentos rurais foi inferior a $\mathrm{R} \$ 4$ bilhões, o que representou apenas $7,7 \%$ do VBP desta safra. Os agricultores familiares demonstraram serem mais eficientes no uso do crédito rural que os agricultores patronais, pois produzem mais com menos recursos do crédito rural (INCRA/FAO, 2000).

Os agricultores familiares representam, portanto, $85,2 \%$ do total de estabelecimentos, ocupam 30,5\% da área total e são responsáveis por 37,9\% do Valor Bruto da Produção Agropecuária Nacional, recebendo apenas $25,3 \%$ do financiamento destinado à agricultura (INCRA/FAO, 2000).

Nestas condições surge uma segunda demanda importante para o uso da terra. Trata-se do oferecimento de postos de trabalho. Dados do Censo Agrícola (1995-1996) mostram que enquanto que o setor patronal da agricultura brasileira representa 785.000 unidades produtoras $\mathrm{o}$ que corresponde a $16,1 \%$ do número de propriedades, o setor familiar da agricultura brasileira responde por 4.075 .000 unidades produtoras $(83,9 \%)$. Em contrapartida, as áreas seguem uma distribuição distinta já que o segmento patronal detém 224.042 .000 hectares que representa $63,5 \%$ da área ocupada pela produção agrícola contra 129.569 .000 hectares ocupados pelo segmento agrícola familiar ou $36,6 \%$.

Segundo o Censo Agropecuário 1995/96, existem no Brasil 4.859.864 estabelecimentos rurais, ocupando uma área de 353,6 milhões de hectares. Nesta safra ${ }^{3}$, o Valor Bruto da Produção (VBP) Agropecuário foi de R \$ 47,8 bilhões e o financiamento total (FT) foi

${ }^{3} \mathrm{O}$ termo safra pode ser aqui utilizado, em virtude do fato de que neste Censo, ao contrário dos anteriores, o período de referência adotado para os dados de produção foi o ano agrícola. 
de $\mathrm{R} \$$ 3,7 bilhões. De acordo com a metodologia adotada, são 4.139.369 estabelecimentos familiares, ocupando uma área de 107,8 milhões de ha, sendo responsáveis por R $\$ 18$,1 bilhões do VBP total, recebendo apenas R\$937 milhões de financiamento rural. Os agricultores patronais são representados por 554.501 estabelecimentos, ocupando 240 milhões de hectares. Os estabelecimentos restantes são formados por aqueles que, conforme já foi mencionado, foram excluídos do universo analisado (FAO/INCRA, 2000).

Planejar programas que conduzam a uma efetiva redução da pobreza rural em um país grande e disperso como o Brasil esbarra no vácuo da base de conhecimentos que permitem conhecer o perfil desta pobreza (WORLD BANK STAFF, 2003).

Por fim, além de representar uma enorme fração dos empregos na área rural, a agricultura familiar também responde por uma fração muito significativa do rendimento do setor agrícola e por fim, a razão econômica já que o setor agrícola respondeu por uma renda de 16.745 milhões de reais no período de 1995-1996 pelos dados do Censo Agrícola.

\subsection{Posse da terra e preservação a mbiental}

Concomitante ao surgimento das primeiras sociedades organizadas, foram criadas normas que regulamentam o acesso e posse da terra. Jean-Jacques Rousseau em seu discurso sobre a origem e os fundamentos da desigualdade entre os homens afirmou: "O primeiro homem que, cercando um terreno, lembrou-se de dizer - isto me pertence - e encontrou criaturas suficientemente simples para acreditar no que dizia, foi o verdadeiro fundador da sociedade civil' (JUNQUEIRA, 1964).

Uma vez que estas sociedades primitivas se basearam na propriedade da terra, surge também a possibilidade do acúmulo de terra como um sinal de riqueza e de poder. Demonstra-se a correlação entre os índices de concentração da renda e da propriedade da terra, bem como com o grau de participação na estrutura de poder (HOFFMANN, 1972).

Desde o período pré-colonial a exploração dos recursos naturais, inicialmente o PauBrasil (Caesalpinea equinata) vem sendo uma fonte de riquezas e de modificação da natureza. Também o acúmulo de terras, desde o período da colonização, através das capitanias hereditárias que atribuíam, por ordem de Dom João III, grande parte do que hoje é o território do Brasil a 12 donatários de 15 capitanias, conforme indica a Figura 1. 


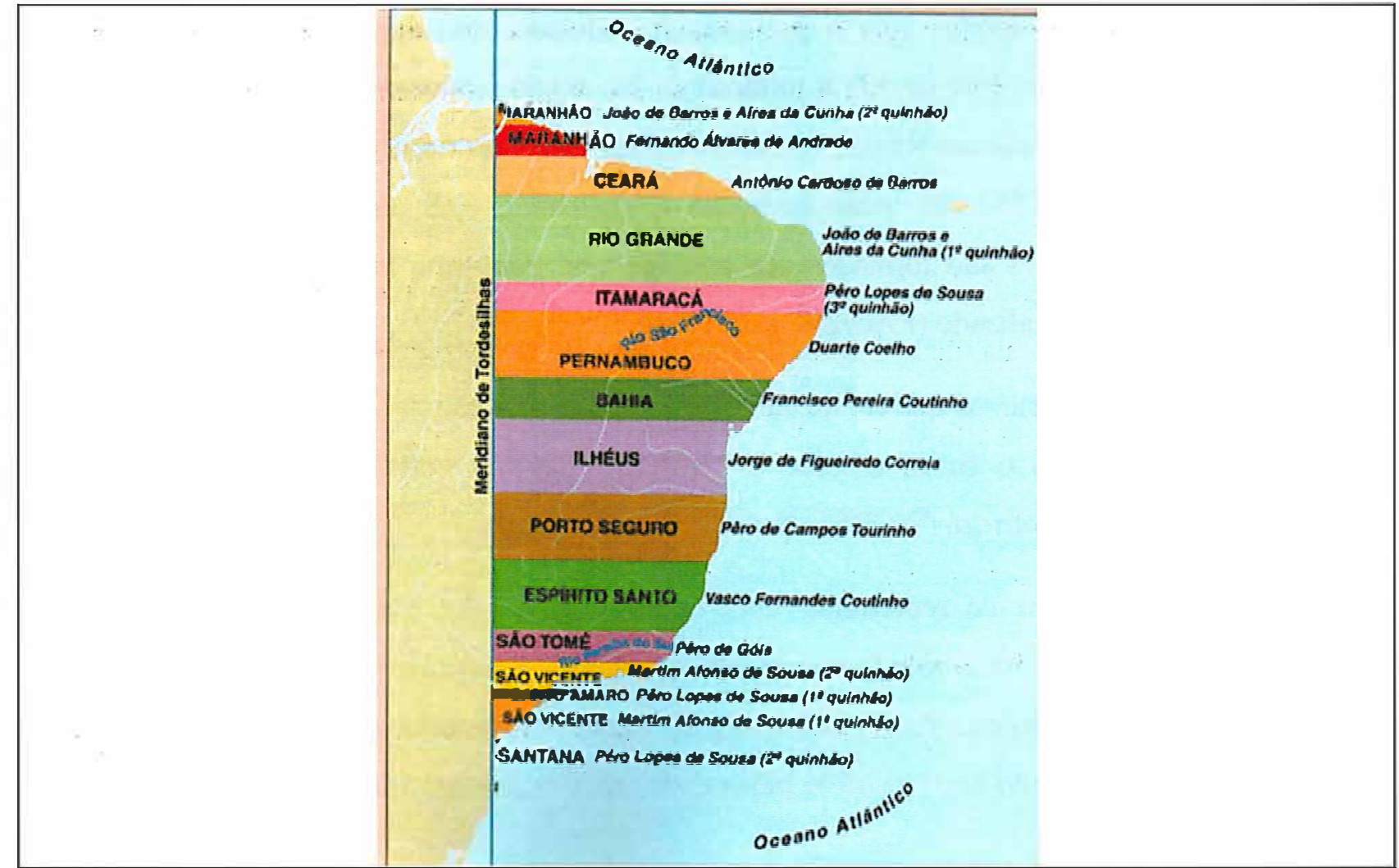

Figura 1 - Mapa de distribuição das capitanias hereditárias, conforme distribuídas por Dom João III

A concessão da posse da terra aos donatários caracterizou a reforma agrária com finalidade de colonização uma vez que, ao pertencerem a portugueses, as terras pertenciam, também a Portugal, não havendo necessidade de investimento público para garantir a posse da terra.

A citação da existência das capitanias hereditárias reside na importância histórica. Eventualmente podem ser identificadas características que persistem até os dias de hoje, tais como a concentração de terras, evidente à medida que 12 donatários receberam áreas, na maior parte dos casos, maior que a área de Portugal.

Reconhece-se, também, a natureza cartorária da posse da terra uma vez que jamais haveria, nos padrões da época, condições para uma efetiva colonização da maior parte das capitanias, entretanto, o registro legitimava a propriedade da terra que, obviamente, ficava desvinculada de qualquer valor social.

A partir de 1964 com o sancionamento da Lei $N^{\circ} 4.504$ de 30 de novembro de 1964 , pelo então presidente Humberto de Alencar Castelo Branco, que regula os direitos e obrigações 
concernentes aos bens imóveis rurais, para os fins de execução da Reforma Agrária e promoção da Política Agrícola passa a existir um estatuto (Estatuto da Terra) que regra a posse e utilização da terra.

$\mathrm{O}$ artigo $2^{\circ}$ assegura a todos a oportunidade de acesso à propriedade da terra, condicionada pela sua função social, na forma prevista na Lei que estabelece no Inciso $1^{\circ}$ que a propriedade da terra desempenha integralmente a sua função social quando, simultaneamente:

a) favorece o bem estar dos proprietários e dos trabalhadores que nela labutam, assim como de suas famílias;

b) mantém níveis satisfatórios de produtividade;

c) assegura a conservação dos recursos naturais;

d) observa as disposições legais que regulam as justas relações de trabalho entre os que a possuem e a cultivem.

Observa-se a preocupação do legislador com a "conservação dos recursos naturais", o que formaliza a associação entre a posse da terra e a conservação ambiental, com óbvia visão do legislador na necessidade de uma explotação sustentável do meio ambiente.

A mudança nos estatutos de posse e uso da terra significa: uma profunda transformação sócio-econômico-política da sociedade; na medida em que altera o perfil de distribuição da renda e do poder. Daí a íntima relação entre processos de movimentos revolucionários com processos de redistribuição dos direitos sobre a terra. Como exemplo podem-se citar revoluções: russa, mexicana, chinesa, cubana, vietnamita, nicaragüense, portuguesa (Revolução dos Cravos) e muitas outras (GUNTELMAN, 1974).

Com a necessidade de se comprovar a propriedade da terra, uma ferramenta se torna de fundamental importância e, talvez tenha sido a única forma de se legitimar a posse de terra: a completa derrubada da floresta e a sua transformação em pastagem ou lavoura. Sendo necessário tal tipo de ação, estreita-se o laço entre a posse da terra, o uso da terra e a geração de impactos ambientais, não pela reforma agrária, mas pelo uso da terra, independente do mecanismo que legitime a propriedade da terra (BEDUSCHI FILHO, 2003). 


\subsection{Reforma agrária e preservação ambiental}

As preocupações ambientalistas e a efetivação da reforma agrária brasileira são contemporâneas. Tanto as preocupações com a preservação e conservação do meio como a legislação brasileira que estabelece a possibilidade de doação de terra com objetivo de se fazer reforma agrária (Estatuto da Terra) remontam a década de 1960.

Uma análise dos dados apresentados pela Fundação ITESP revela a implantação de 165 projetos de assentamento, em terras de domínio estadual e federal, os quais ocuparam uma área total de 219.748,97 ha do Estado de São Paulo, desde o primeiro assentamento, o Primavera na cidade de Andradina de 1981 até o assentamento Santo Antonio em Mirante do Paranapanema, iniciado em março de 2005 (ITESP, 2005).

Sendo assim, a devastação da mata originalmente encontrada no Estado de São Paulo, conforme ilustra a Figura 2, não pode ser atribuída à Reforma Agrária uma vez que a maior parte do desmatamento ocorre anteriormente à implementação da Reforma Agrária e muito mais jomumente, em áreas não destinadas a esta finalidade.

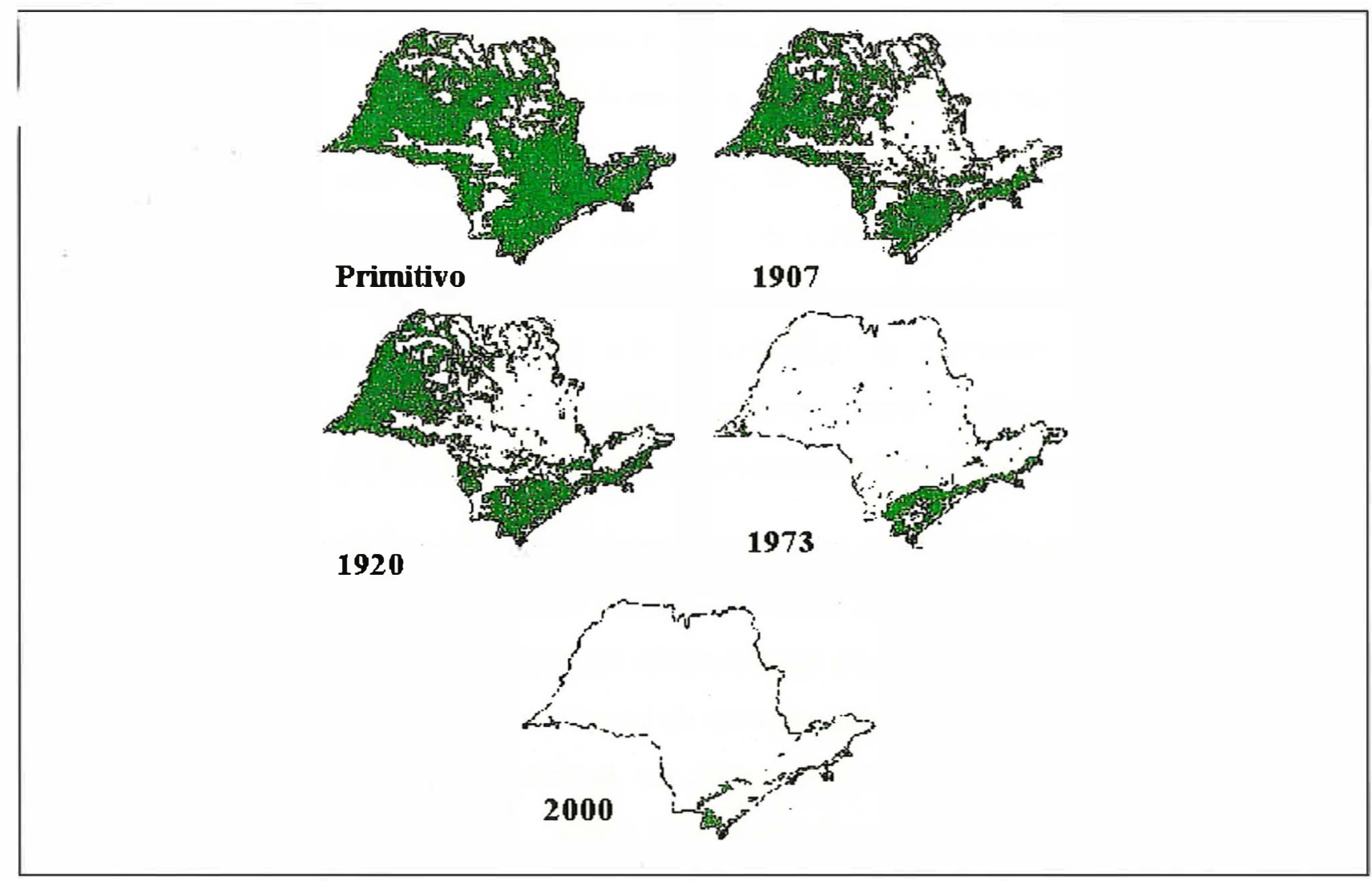

Figura 2 - Reconstituição da cobertura vegetal natural do Estado de São Paulo 
Observe-se que no Estado de São Paulo, as atividades pioneiras de implantação de assentamentos com finalidade de reforma agrária datam do ano de 1960 quando dois projetos pilotos foram criados, um em Campinas com 72 famílias assentadas e outro em Marília, inicialmente com 103 famílias (BERGAMASCO; NORDER, 2003).

No quadro posterior à Segunda Guerra Mundial, os anos 1950 testemunham a emergência de um pensamento crítico aos efeitos negativos do crescimento econômico, em termos de justiça social e de empobrecimento relativo de alguns países e regiões. Um dos primeiros economistas a lançar este alerta foi o sueco Gunnar Myrdal (Prêmio Nobel de Economia de 1974), que chamou a atenção para o "ciclo vicioso da pobreza", que se produzia como corolário do padrão de crescimento econômico vigente (BARTHOLO JÚNIOR; BURSZTYN, 2001).

No período da colonização, foi escolhida a escravidão, pior tipo de pobreza, como mão-de-obra da produção, ao invés de serem escolhidos trabalhadores livres, produzindo para eles próprios. A escravidão cria riquezas, mas não reduz a pobreza dos escravos. Mesmo com a libertação dos escravos, foi mantida a fábrica de pobreza chamada latifúndio exportador. A riqueza crescia e o número de pobres também (BUARQUE, 2004).

Em vista da história brasileira, fazem-se necessárias medidas que busquem a mitigação da pobreza. Diversos estudos do custo por beneficiário da reforma agrária concordam: são produzidos resultados com investimentos na faixa entre $R \$ 15.000,00$ e $R \$ 50.000,00$ por família, de acordo com a região. Considerando-se o fato de que a reforma agrária cria uma fonte de renda sustentável para os beneficiários, o custo da reforma, no extremo inferior da faixa é favorável como estratégia alternativa. O custo de um simples lote urbano com os serviços públicos básicos em uma cidade nordestina de tamanho médio varia tipicamente entre $\mathrm{R} \$ 8.000,00$ e $\mathrm{R} \$ 10.000,00$. O custo do investimento por vaga de emprego no setor industrial está acima de $\mathrm{R} \$ 30.000,00$ (AMSBERG, 2003).

As mudanças econômicas dos anos recentes fizeram da reforma agrária um investimento que pode ser efetiva na redução da pobreza e da desigualdade enquanto que ao mesmo tempo aumenta a eficiência da economia rural (AMSBERG, 2003). Basta citar que do total produzido pelo setor agropecuário, o segmento patronal respondeu no período por $53,6 \%$ da 
renda do setor agrícola e o setor familiar por $46,4 \%$ da renda do setor agrícola (DIAS; BARROS, 2003).

Um efetivo programa de reforma agrária, de acordo com a experiência internacional, pode ter repercussões que extrapolam os limites do campo atingindo toda a sociedade e envolvendo os seus mais diversos setores. Os impactos podem ocorrer sobre os pontos de vista econômico, social e político. Há praticamente, um consenso de que tanto a reforma agrária quanto a preservação do meio ambiente e a conservação do solo são necessárias e inadiáveis. Mais, que são fundamentais para o processo de desenvolvimento econômico, principalmente quando este é analisado desde uma perspectiva de médio e longo prazo. Dificilmente se encontra hoje, entre as mais diversas correntes de pensamento, alguém se seja contrário à reforma agrária e à preservação do meio ambiente. Há inúmeros estudos demonstrando a sua importância e a sua relevância para a sociedade brasileira (GUEDES PINTO, 1988).

A contribuição da agricultura familiar, além dos aspectos já tratados favorece a população brasileira urbana à medida que a redução da pobreza é garantida pela extinção da fome, e isto depende da reforma agrária e da produção para o mercado interno reduzindo-se a importância relativa das exportações (BUARQUE, 2004).

\subsection{Metodologia para avaliação da percepção}

A inclusão do papel predominante desempenhado pelo homem na biosfera foi uma contribuição importante para o campo dos estudos ecológicos, e corresponde a uma evolução da própria ciência ecológica uma vez que esta passou a estender seu alcance para além dos aspectos físicos e biológicos do meio ambiente, incluindo o homem "dentro" da biosfera e tomando em consideração a parcela do imponderável que existe na mente humana (CASTELLO, 1996). É este imponderável que acaba regulando as mudanças no uso de recursos a partir das percepções que indivíduos e grupos têm a respeito deles.

A ecologia tradicional visualizava a ação do homem como uma "externalidade", como um modificador dos ecossistemas, considerando-o um fator de perturbação; como uma mudança climática ou uma alteração sísmica, por exemplo (DI CASTRI, 1982; citado por CASTELLO,1996). 
Justifica-se desta forma, a aplicação de métodos que avaliem a percep̧̧ão ambiental a partir da introdução do homem como ator participante do processo ecológico e não como externalidade.

A preocupação com a caça também orienta este trabalho uma vez que esta pode ser indicadora da percepção e dos efeitos das atividades humanas sobre o ambiente. A caça ilegal é um dos fatores que geram perda na biodiversidade e a degradação das florestas próximas a comunidades rurais. Ao longo do tempo estes impactos modificam a estrutura da floresta e afetam processos ecológicos e causam significativas perdas de espécies de plantas e animais (VALLADARES-PÁDUA; PÁDUA; CULLEN JÚNIOR, 2002), justifica-se com isto a introdução no questionário desenvolvido para este estudo, de questões inerentes à caça e seu uso na determinação dos indicadores de percepção ambiental.

Um referencial teórico que visa relacionar comportamento e ambiente para, da análise detida das relações entre os dois fatores, gerar diretrizes para o equacionamento de sua interrelação. E, em instâncias subseqüentes operacionalizar o projeto destas inter-relações, via intervenção de planejamento urbano (CASTELLO, 1996).

Esta linha de trabalho é muito coerente com a do atual estudo uma vez que se pretende o estabelecimento de um referencial teórico que permita o mesmo tipo de efeito, mas através da intervenção de planejamento agrário e os mesmos princípios, provavelmente se mostrarão necessários reconhecimento de espaços de mensuração objetiva e subjetiva que se complementam e permitem a avaliação de uma realidade, mas diante da inclusão do homem e sua ação na biosfera e, mais especificamente em fragmentos florestais próximos às áreas agrícolas a eles destinados pelo processo de reforma agrária.

A maioria da população rural (em torno de $70 \%$ ) no sudeste do Brasil; incluindo-se os atuais migrantes "sem terra" que vivem no Pontal do Paranapanema; não são familiarizados com a floresta tropical. Muitos não têm tradição de caçadores de subsistência e coletores, tendo apenas experiência com a agricultura comercial, já que foram empregados como trabalhadores permanentes em fazendas. Em torno de $20 \%$ passou a maior parte de suas vidas em centros urbanos e a maior parte dos que restaram são oportunistas que esperam um pedaço de terra para que possam, posteriormente, vendê-lo (VALLADARES-PÁDUA; PÁDUA; CULLEN JÚNIOR, 2002). 
Tal percepção indica a necessidade de que se pesquise a origem e a experiência anterior dos entrevistados uma vez que sua percepção pode estar intimamente ligada com sua vida anterior à do assentamento.

Adicionalmente, no Estado de São Paulo encontra-se remanescentes de mata original muito fragmentados. O valor biológico destes pequenos remanescentes de floresta atlântica é inquestionável. Algumas são matas de galerias que protegem os cursos d'água e promovem a conservação do solo. Os fragmentos são habitados por espécies que dispersam e polinizam a vegetação nativa, aumentando o fluxo genético regional. Servem, ainda, como refúgio para aves migratórias locais e de grande-distância. Por fim, e mais importante, tratam-se de bancos de sementes para estes ecossistemas em perigo e podem ser usados para programas de restauração florestal (VALLADARES-PÁDUA; PÁDUA; CULLEN JÚNIOR, 2002).

Tudo isto embute caracteres importantes na pesquisa da percepção dos assentados, pois pode ser prevista a sua ação nas áreas de assentamento, tanto através da caça ilegal como da erosão em áreas próximas aos fragmentos como pela ação do fogo, da dessecação pelo vento, pela distribuição de plantas invasoras e uso de pesticidas, fatores.

A aplicação de questionários se mostra uma prática que permite uma coleta sistematizada de informações mensuráveis, facilitando padronização do diálogo e o tratamento de resultados (DIEDERICHSEN, 2003). Trata-se de uma opção que vem sendo utilizada em estudos similares.

Adicionalmente foram incorporadas no questionário, perguntas inerentes ao uso de recursos florestais e hídricos, conhecimento sobre práticas de conservação do solo e seus respectivos usos, parâmetros de escolaridade, uso de agrotóxicos, participação de treinamentos e capacitação para implantação de recursos florestais, conforme modelo desenvolvido de questionário de avaliação da percepção ambiental proposto por DITT et al, 2003. 
4 MATERIAL E MÉTODOS

"Então, do pó da terra, o SENHOR formou o ser humano. O SENHOR soprou no nariz dele uma respiração de vida, e assim ele se tornou um ser vivo".

Gênesis 2

\subsection{Aplicação de Questionário para avaliação da percepção ambiental}

O questionário semi-estruturado utilizado combina questões abertas e fechadas na forma de entrevistas. As etapas para a construção do questionário foram as seguintes: a busca da fundamentação teórica sobre o tema, destacando-se os trabalhos de DITT et al. (2003), COSTA (2003); a construção dos instrumentos para a pesquisa de campo; a definição do campo e as aproximações com o campo de aplicação. Uma vez definida uma primeira versão do questionário, foram feitas aplicações piloto que nortearam a evolução até a versão final.

Através da aplicação dos questionários e da sistematização das informações recolhidas, espera-se a obtenção de indicadores que reflitam o grau de percepção ambiental dos produtores rurais. A versão final do questionário desenvolvido especificamente para este estudo se encontra no ANEXO A.

O questionário conta com questões agrupadas em 14 tópicos que permitem a coleta de informações de três tipos: a) informações sobre a entrevista composto pelos tópicos 1 . Informações Iniciais e 14. Informações Finais.

Estas informações objetivam avaliar a receptividade do entrevistado, a sua identificação e a de seu lote, a posição do lote em relação à proximidade de áreas de reserva legal e áreas de proteção permanente, bem como a posição do entrevistado dentro da família.

Eventualmente estas informações podem ser usadas na classificação dos dados e no estabelecimento de fatores do estudo.

Os itens 2, 3 e 4 do questionário objetivam obter variáveis classificatórias as quais poderão ser usadas na quantificação estratificada das respostas. Eventualmente, explicações sobre efeitos podem recair em grupos formados através das variáveis aqui agrupadas. 
Por fim, os itens compreendidos entre os números 5 e 13 são as medidas que permitirão a avaliação da percepção ambiental sob diversos pontos de vista: atitude conservacionista; uso de defensivo agrícola; fauna silvestre; recursos hídricos; resíduos sólidos; conservação do solo; capacitação ambiental; reflorestamento e meio ambiente.

O questionário foi desenvolvido em escritório e aperfeiçoado através de aplicações em projetos piloto que mudaram a forma e o conteúdo da versão preliminar. No desenvolvimento do questionário foram adotadas as seguintes diretrizes:

Foram feitas perguntas claras e com significados iguais para todos os entrevistados. Por vezes, a terminologia específica da área ambiental foi substituída por termos coloquiais que, apesar de menos precisos mantinham um sentido suficientemente próximo do compreendido pelos entrevistados.

Uma vez concluída a aplicação dos questionários os dados foram digitados disponibilizados para a análise estatística.

\subsection{Entrevistadores}

Os entrevistadores foram selecionados através de atributos listados dos quais se destacam:

- Bons conhecimentos técnicos sobre os tópicos abordados no questionário. Deu-se preferência para alunos de cursos de graduação em engenharia agronômica, ecologia, engenharia florestal, ciências biológicas ou cursos superiores concluídos em qualquer área de conhecimento (professor, agrônomo, advogado, engenheiro civil).

- Simpatia e capacidade de inspirar confiança nos entrevistados;

- Espírito de observação profundo de tal maneira que pudessem tirar proveito máximo das coisas que pudessem perceber durante a entrevista;

- Facilidade de comunicação e de adaptação - de modo que pudessem interagir com pessoas dos mais diferentes níveis;

Através de um treinamento aplicado em todos os entrevistadores, objetivou-se fazer com que as entrevistas fossem facilitadas através de: 
- Pleno conhecimento a respeito dos termos adotados no questionário, inclusive para prover informações necessárias aos entrevistados quando estas se mostrassem necessárias;

- Objetivos implícitos e explícitos em cada questão de forma que os entrevistadores soubessem quando poderiam fornecer maiores explicações sem que se ferissem os objetivos das questões formuladas;

- Pudessem seguir estritamente os requisitos de imparcialidade, necessário para validar a aplicação do questionário como ferramenta de percepção das opiniões do entrevistado e não do próprio entrevistador;

- Os entrevistadores foram instruídos a efetuar as perguntas exatamente como elas se encontravam no questionário;

- A ordem das questões deveria ser seguida de acordo como apareciam no questionário;

\subsection{Delineamento amostral}

Com vistas à obtenção de uma amostra representativa e da população desejada: Assentados do Estado de São Paulo para finalidade de Reforma Agrária se partiu para um processo de amostragem estratificada em dois estágios (COCHRAN, 1977).

A estratificação foi feita com os dados de coletados por SPAROVEK, 2002, trabalho no qual foi usado um questionário para obtenção dos dados. Tal questionário conta com uma seção composta de nove perguntas que se referem ao estado de preservação das áreas de preservação permanente e reserva legal, extração ilegal de produtos florestais, caça ou captura de animais silvestres, degradação dos solos por erosão ou salinização, desmatamento após a criação do projeto de assentamento (PA), plantio de árvores ou ações de melhoria da qualidade ambiental e à existência de atividade minerária ilegal.

A análise de agrupamento foi calculado pelo método "average linkage" (SOKAL; MICHENER, 1958) que forma grupos baseados na técnica aglomerativa usual de agrupamentos hierárquicos. Cada observação começa em um grupo individual. Os dois grupos mais próximos são agrupados em um novo grupo que substitui os dois grupos anteriores. A união dos dois grupos mais similares se repete até que somente resta um grupo que contém todas as observações. O método average linkage determina o uso da média do agrupamento de pares não ponderados 
usando as médias aritméticas, UPGMA. A distâncias foram elevadas ao quadrado (SAS Institute Inc, 1989). Para a determinação da distância crítica utilizou-se a estatística Pseudo- $\mathrm{t}^{2}$ como indicadora de pontos apropriados para o estabelecimento dos grupos.

A análise permitiu o agrupamento dos assentamentos similares os quais foram considerados como extratos. Foram definidos através da análise de agrupamento, 16 estratos dentro dos quais foram feitos os sorteios dos assentamentos que receberiam a visita dos entrevistadores.

Por se tratar de uma amostra estratificada, cada estrato terá, pelo menos, um projeto de assentamento avaliado. Estratos composto por 1 único assentamento teve este como selecionado e estratos com mais de um assentamento teve o(s) assentamento(s) definidos através de sorteio. A análise de agrupamento e o sorteio foram realizados através do Sistema SAS.

\subsection{Intensidade amostral dos assentamentos}

Determinados os estratos iniciou-se o processo de seleção dos assentamentos que compuseram a amostra. Para tanto, como o interesse é a representatividade na escala estadual, calculou-se o número de assentamentos necessários para que se representem todos os assentamentos do Estado de São Paulo e isto foi feito através do método de cálculo do tamanho de amostras (eq. 1).

$$
S S=\frac{Z^{2} \times p \times(1-p)}{c^{2}}
$$

Os parâmetros especificados na eq. 1 têm os seguintes significados:

SS: Tamanho da amostra calculado.

Z: $\quad$ ordenada da distribuição normal para um nível de significância previamente estabelecido. Como foi adotado um nível de significância de 5\%, o valor usado para Z foi 1,96 (LEAL, 1981).

p: $\quad$ Probabilidade de selecionar uma opção que é 0,5 para o caso do cálculo do tamanho da amostra 
c: Intervalo de confiança expresso como decimal inteiro. Para o intervalo de confiança de $13 \%$, adotado neste estudo usou-se em eq. 1 o valor 0,13 .

Em vista da necessidade da aplicação da correção para populações finitas, o resultado obtido em eq. 1 foi aplicado em eq. 2

$$
\text { Tamanho da amostra }=\frac{S S}{\left(1+\frac{(S S-1)}{p o p}\right)}
$$

E os parâmetros de eq. 2 têm os significados descritos em seguida.

SS: $\quad$ Tamanho da amostra calculado corrigido para populações finitas.

pop: Tamanho da população que para o estabelecimento do número de assentamentos que compuseram a amostra foi 151 .

O cálculo do tamanho da amostra necessário resultou em 41,49; por isto, foi determinado que a amostra seria composta por 42 assentamentos.

O mesmo processo foi utilizado para se determinar o número de lotes a se amostrar dentro de cada assentamento, mas desta feita modificou-se o intervalo de confiança (c) para $20 \%$, ao invés de $13 \%$ usados na determinação do número de assentamentos e considerou-se o número de lotes de cada assentamento como a população a ser amostrada.

\subsection{Primeiro nível de amostragem}

Para garantir a representatividade decorrente do processo de estratificação iniciou-se o processo de seleção dos assentamentos que compuseram a amostra. Para tanto, partiu-se dos estratos criados através da análise de agrupamento e foram selecionados todos os assentamentos de grupos unitários. Isto foi feito para garantir a representatividade de todos os estratos formados e, com isto, foram selecionados os seguintes assentamentos: Primavera (Grupo 4), Reunidas (Grupo 5), Flor Roxa (Grupo 9), Monte Alegre 3 (Grupo 10) e Santa Carmem (Grupo 16).

Como ainda era necessária a determinação de 37 assentamentos de um total de 145 considerou-se que estratos com 2 assentamentos requereriam 1 assentamento na amostra e então, através de sorteio programado no sistema SAS foram selecionados em cada estrato com 2 
46

assentamentos um assentamento, o que resultou na seguinte lista: Gleba XV de Novembro (Grupo 1), Santa Lúcia (Grupo 2).

Nos estratos com 3 e 4 assentamentos foram aleatoriamente selecionados 2 deles o que resultou na seguinte seleção: Marco II e Santa Rita do Caiuá (grupo 3); Tremembé e Pirituba II - Área 2 (Grupo 6); Água Sumida e Santa Rita I (Grupo 8); Monte Alegre 2 e Engenho (Grupo 11); Bueno de Andrada e Silvânia (Grupo 12).

Grupos com 10 e 11 assentamentos tiveram 3 deles aleatoriamente selecionados: Guarani, Zumbi dos Palmares e Boa Sorte (Grupo 7) e Nova Esperança, Monte Alegre 4 e Santa Terezinha da Alcídia (Grupo 15).

O grupo 13, com 15 assentamentos teve 4 deles aleatoriamente selecionados: Pirituba II-Área 3, Ipanema, Esmeralda e Antonio Conselheiro II.

Por fim, do Grupo mais numeroso com 79 assentamentos, foram selecionados "a priori" 11 assentamentos: Chico Castro Alves, Camaquã, Pirituba II-Área 1, São José I, Nova Vida, Santa Rosa I, Estrela D’alva, Santa Isabel, Sumaré I, Santo Antonio dos Coqueiros e Haroldina. O número, inferior ao desejado inicialmente, foi complementado no decorrer do levantamento e, deste grupo especificamente, chegou-se a 17 dos 19 pretendidos após a inclusão dos assentamentos Vale Verde, Pirituba II - Área 4, Pirituba II - Área 5, Pirituba II - Área 6, Cachoeira do Estreito e Santa Rita da Serra. A redução do número de assentamentos deste grupo, todavia, não deve causar estranheza por ser o mais homogêneo dentre todos já que no processo de estratificação este foi o composto pelos assentamentos de menor distância. Também foram incorporados posteriormente os assentamentos São Bento (Grupo 11), Haidéia e Santa Vitória (Grupo 13) e Vista Alegre (Grupo 2).

\subsection{Segundo nível de amostragem}

Uma vez definida a intensidade de amostragem dos assentamentos e se ter procedido ao sorteio dos assentamentos, de forma a se ter uma amostra representativa do Estado de São Paulo, definiu-se um segundo estágio da amostragem na qual foram determinados os números de lotes representativos em cada um dos projetos de assentamento. 
Para esta fase da amostragem foi aplicado um intervalo de confiança de 20 pontos, nível de significância de $5 \%$ e população variável de acordo com o número de lotes de cada um dos projetos de assentamento.

A casualização dos lotes foi feita preliminarmente ao conhecimento do assentamento quando havia mapa disponível. Na maior parte das vezes, todavia, a aleatorização foi feita no campo de forma que se tomava um determinado caminho e se decidia aplicar o questionário em uma propriedade que ficasse um determinado número de lotes à frente e de um dos lados desta via. Muitas vezes em vista da impossibilidade de aplicação do questionário no lote sorteado se aplicava no lote vizinho.

Deu-se preferência, sempre ao equilíbrio entre os lotes que fossem, ou não, vizinhos de áreas de reserva legal e proteção permanente para que se captassem as opiniões dos moradores destas duas situações.

Não foram entrevistados assentados que tivessem participado, mesmo que como ouvintes, da aplicação do questionário em propriedade diferente da dele.

Uma vez explicados os objetivos da pesquisa e o caráter voluntário de participação, assim como ser dada plena garantia de sigilo aos possíveis entrevistados era feito o convite para que eles respondessem as perguntas do questionário. Somente após a aceitação que o lote passava a ser efetivamente uma amostra dentro da pesquisa. Lotes nos quais houve resposta negativa ou impossibilidade de resposta não foram contabilizados como amostra.

\subsection{Digitação dos dados}

Paralelamente ao desenvolvimento dos trabalhos de campo onde eram coletadas informações através do questionário desenvolvido para este estudo, um software específico foi programado utilizando-se a linguagem Microsoft Visual Basic ${ }^{\circledR}$ e o banco de dados Microsoft Access ${ }^{\circledR}$.

Este software manteve estreita associação com a forma de preenchimento dos questionários e, através de definições programadas, orientou a digitação dos dados de forma coerente com o preenchimento do questionário. 
A estruturação da base de dados permitiu que se incorporassem mecanismos que evitaram a "digitação livre" dos campos abertos. Permitiu ainda a incorporação de mecanismos que impedem o preenchimento de questões incoerentes em vista de respostas dadas em perguntas que se completam.

O uso de caixas de texto que permitem a digitação de qualquer conteúdo, de forma livre, sempre que possível, foi substituída por listas nas quais as respostas previamente digitadas aparecem como opcionais em detrimento da obrigatoriedade da re-digitação de textos de similar significado.

\subsection{Pré-processamento}

Apesar de todos os mecanismos incorporados ao software de digitação de dados, foram identificados problemas na transcrição do conteúdo registrado no questionário e tiveram que sofrer processo de depuração a fimm de se manter a coesão para a análise dos resultados.

Foram identificados problemas de digitação do código identificador do questionário que precisaram ser corrigidos e problemas de digitação de questões abertas que foram corrigidos de acordo com a terminologia mais apropriada e com a grafia das palavras pronunciadas de forma coloquiais e, muitas vezes, digitadas como pronunciadas.

Em função deste tipo de problema é que se evitou o uso de questões abertas, mas quando isto não foi possível, houve o cuidado de se aprimorar os dados.

Não foram adotados mecanismos de imputação, ou seja, perguntas não respondidas receberam o "status" de "dado não fornecido", objetivando-se manter a fidelidade aos registros anotados pelo entrevistador.

\subsection{Processamento}

Todo o processamento de dados foi feito no Sistema SAS a partir da importação das bases de dados Access.

A fase crucial do processamento foi o desenvolvimento de indicadores que permitissem congregar as informações ambientais de forma consistente e com características tais que possibilitassem a aplicação de técnicas estatísticas que apoiassem as discussões suscitadas na fase de delineamento do projeto. 
Foram desenvolvidos 6 indicadores cada um deles referente a um tipo de impacto ou percepção ambiental.

\subsection{1 Índice de geral de diversidade do uso da terra $(I G D)$}

O primeiro índice apresentado foi o índice geral de diversidade da produção que busca caracterizar os sistemas produtivos adotados na propriedade. Este índice quantifica o número de atividades produtivas de distintos tipos conduzidos na propriedade, tanto com finalidade comercial como com finalidade de consumo familiar. O índice é calculado com base em todas as opções da questão 4.7 do questionário.

Tomou-se por base a existência das seguintes atividades na propriedade rural estudada: cultura anual, horta, cultura perene, sistemas agroflorestais, animais de criação, pastagem e outras. As atividades acima descritas podem ser conduzidas com finalidade comercial elou com finalidade de consumo familiar.

Para calcular o índice geral de diversidade do uso da terra somam-se todos os itens existentes na propriedade e divide-se por 13 , conforme eq. 3.

$$
I G D_{j}=\frac{\sum_{i=1}^{13} U T_{i}}{13}
$$

Onde:

j: $\quad$ indicador do questionário.

$i$ : $\quad$ indicador dos diferentes usos da terra;

$U T_{i}: \quad$ indicador do uso da terra para as diferentes atividades pesquisadas e valendo 1 , quando a terra é usada para a i-ésima finalidade e 0 para quando ela não recebe a utilidade em questão. São os seguintes os Usos da Terra definidos no questionário e usados no cálculo do IGD: Cultura Anual Comercial, Cultura Anual Consumo, Cultura Perene Comercial, Cultura Perene para consumo, Horta Comercial, Horta Consumo, Sistema Agroflorestal Comercial, Sistema Agroflorestal Consumo, Animais de Criação Comercial, Animais de Criação Consumo, Outros Usos Comercial, Outros Usos Consumo, Pastagem. 
Valores próximos a 1,0 indicam maior diversidade de atividades produtivas e o valor 0 representa que não são desenvolvidas atividades produtivas no lote. Dentro deste intervalo os valores se referem a um número intermediário de atividades.

\subsection{2 Índice de Interação com a Mata (IIM)}

O IIM é calculado a partir dos indicadores de uso de recursos florestais ponderado pela interação gerada com o uso em questão. Ele é calculado com base no item 5.2 do questionário nos quesitos de aproveitamento passado e futuro dos recursos florestais.

Uma maior interação implica em um maior uso dos recursos e a ciência de sua existência. O cálculo é descrito em eq. 4.

$$
I I M_{j}=\frac{\sum_{i=1}^{\prime \prime} U R F_{i} \times \text { Peso }_{i}}{35}
$$

Onde:

$j: \quad$ indicador do questionário.

$i$ indicador dos diferentes usos de recursos florestais que são.

$U R F_{i}$ : indicador do Uso de Recursos Florestais recebendo valor 1 quando foi indicado o i-ésima finalidade e 0 para quando ela não recebe a utilidade em questão. Foram os seguintes os diferentes usos de Recursos Florestais especificados no questionário e usados no cálculo do IIM, com os respectivos pesos entre parênteses: cabo de enxada (3), lenha para fogão(2), lenha para carvão(1), apicultura(5), madeira para cerca(2), madeira para construção(2), medicamentos(5), passear(3), pasto para animais(1), carne de caça(5) e plantio de floresta nativa (6).

Os pesos foram estabelecidos com o maior tempo e conhecimento envolvido nas diversas atividades. Sendo assim, deu-se peso máximo (6) ao plantio de floresta nativa, pesos grandes (5) às atividades que requerem mais tempo de interação ou mais conhecimento sobre os recursos, tais como apicultura, caça, coleta de medicamentos e caça. Peso 1 foi dado às atividades que denotam menor interação com a mata tais como pasto para animais e lenha para carvão pois o tempo de interação e os conhecimentos necessários, sobre a mata, para realização de tais tarefas é mínimo. Entre os extremos foram arbitrados valores intermediários para atividades que exijam 
menos interação elou conhecimento que o primeiro grupo e mais interação e conhecimento que o segundo grupo de atividades.

O índice 1 representa o máximo de interação com a mata ao passo que o índice 0 indica nenhuma interação com a mata. Entre estes valores se situam níveis intermediários de interação com a mata.

\subsection{3 Índice de percepção de erosão do solo (IES)}

O IES avalia a capacidade de percepção da erosão do solo. Para este índice foram usadas as questões do item 10.1, 10.3, 10.4, 10.7, e 11.9 em duas opções: a de que erosão é um problema do assentamento e dela ser o mais grave dos problemas do assentamento.

O cálculo é descrito em eq. 5 .

$$
I E S_{j}=\frac{\sum_{i=1}^{6} V E_{i}}{6}
$$

Onde:

j: $\quad$ indicador do questionário.

$i: \quad$ indicador das diferentes formas de se avaliar a erosão.

$V E_{i}$ : indicador da percepção da existência de erosão recebendo valor 1 quando foi indicado o iésima fator de percepção e 0 para quando ela não demonstra ter percepção. São os seguintes os indicadores contemplados no questionário e utilizados no cálculo do IES: saber o que é erosão do solo, saber que no próprio lote tem erosão do solo, conhecer técnicas para combate da erosão, saber o que é plantio direto, considerar que erosão do solo é um problema grave que ocorre no assentamento e, por fim, considerar que este é o problema mais grave que ocorre no assentamento.

O valor 1 indica o máximo de percepção de erosão ao passo que o índice 0 indica nenhuma percepção de erosão. Entre estes valores se situam níveis intermediários de percepção de erosão do solo.

Por se tratar de um índice de percepção, não se está preocupado com a existência da erosão, mas sim com a percepção. Caso ela não exista no assentamento, ela não pode ser percebida, portanto o índice de percepção deve resultar em um valor baixo. 


\subsection{4 Índice de percepção de impacto sobre os recursos florestais (IRF)}

O IRF avalia a capacidade de percepção do impacto sobre os recursos florestais. O cálculo que utiliza as respostas às questões 5.2, 5.3, 11.9 e 10.11 é descrito em eq. 6 .

$$
I R F_{j}=\frac{\sum_{i=1}^{4} R F_{i} \times \text { Peso }_{i}}{100}
$$

Onde:

$j: \quad$ indicador do questionário.

$i: \quad$ indicador dos diferentes tipos de impactos aos recursos florestais.

$R F_{i}$ : indicador da percepção da existência de impacto sobre os recursos florestais calculado com base nas respostas do questionário São os seguintes os indicadores contemplados no questionário e utilizados no cálculo do $I R F$ com os respectivos pesos especificados entre parênteses: uso presente ou passado de recursos florestais (25), presenciou desmatamento (10), considera grave algum dos problemas relacionados ao uso de recursos florestais (35), percebe a existência de impacto causado pelo fogo nas áreas de floresta (30).

Os pesos foram estabelecidos de forma proporcional aos impactos causados pelos itens em estudo. Considerar que algum problema que afete os recursos florestais é o mais grave denota o que foi considerada como máxima percepção, pois para que isto ocorra o assentado deve perceber o problema e estabelecer um juízo a respeito de sua gravidade, daí o maior peso. O segundo maior peso é o do fogo já que é facilmente percebido quando ocorre e de impacto reconhecidamente grande. $\mathrm{O}$ uso passado ou presente de recursos florestais é o terceiro item e de impacto certamente menor que o fogo. Por fim, o menor peso é dado a ter presenciado a retirada de árvores das áreas de RL e APP uma vez que, em função da fiscalização, isto não tem sido feito de forma que gere tanto impacto, mas em pequena escala.

Valores próximos a 1 denotam maior percepção de prejuízos provocados sobre os recursos florestais ao passo que valores próximos 0 indicam que não são percebidos impactos significativos sobre os recursos florestais. 


\subsection{5 Índice de percepção do impacto do uso de recursos hídricos (IRH)}

O IRH avalia a capacidade de percepção do impacto do uso de recursos hídricos pelos assentados. O cálculo se utiliza de respostas às questões $6.5,8.4,8.5,9.1,9.2$, 5.6 e 10.3 é descrito em eq. 7.

$$
I R H_{j}=\frac{\sum_{i=1}^{8} R H_{i} \times \text { Peso }_{i}}{100}
$$

Onde:

$j: \quad$ indicador do questionário.

$i: \quad$ indicador dos diferentes tipos de impacto aos Recursos Hídricos.

$R H_{i}:$ indicador da percepção da existência de impacto sob os recursos hídricos Os valores obtido a partir das respostas do questionário usado no cálculo do $I R H$ e os respectivos pesos entre parênteses são apresentados em seguida: resíduos de agrotóxicos lançados na água (29), destina esgoto doméstico para cursos d'água(17), saber que a água do assentamento pode ser prejudicada pela ação antrópica (5), lança lixo nos cursos d'água(5), observa que outros lançam lixo nos cursos d'água (5), observa uso inapropriado das margens do curso d'água (5), percebe o assoreamento (5), percebe a gravidade dos problemas relacionados à água (29).

Os pesos atribuídos de forma proporcional ao impacto gerado pelo fator em questão. Sendo assim perceber que o problema mais grave está relacionado com recursos hídricos implica na aceitação de que há grande impacto deste fator sobre o assentamento, por isto o maior peso, similar ao impacto causado por contaminação por agrotóxicos. O terceiro seria a contaminação por esgoto doméstico, menos impactante que os anteriores e mais que os outros fatores considerados no assentamento, os quais não tiveram ponderações diferenciais entre si.

Valores próximos a 1 denotam uma maior percepção da existência de efeitos negativos afetando os recursos hídricos ao passo que valores próximos a 0 denotam que não são percebidos fatores que prejudicam os recursos hídricos do assentamento. 


\subsection{6 Índice de percepção de impacto sobre a fauna pela caça (ICA).}

O ICA avalia a capacidade de percepção do impacto decorrente da caça. O cálculo que utiliza as respostas às questões 5.2, 7.2, 11.9 é descrito em eq. 8 .

$$
I C A_{j}=\frac{\sum_{i=1}^{5} I C_{i}}{5}
$$

Onde:

$j: \quad$ indicador do questionário;

$i$ : $\quad$ indicador das diferentes formas de avaliação do impacto da caça.

$I C_{i}$ : indicador de percepção usado para avaliação dos diversos impactos de caça: já ter caçado ou ainda caçar, saber da existência de caça no assentamento, percebe a gravidade dos problemas relacionados à caça e atribui a este problema a maior importância dentro dos problemas ambientais presenciados no assentamento.

Valores próximos a 1 indicam a percepção da existência de impacto causado pela caça e valores próximos a 0 indicam que impactos de caça não são percebidos.

\subsection{Análise discriminante}

Através do desenvolvimento de funções discriminantes podem-se classificar as observações em dois ou mais grupos com base em uma ou mais variáveis quantitativas.

Os índices de impacto e percepção ambiental são variáveis quantitativas que podem ser usadas no desenvolvimento de critérios discriminantes que permitam a classificação da observação em um ou mais grupos, o cálculo de distância entre estes grupos e testes para comparação da existência de diferenças entre os grupos.

A aplicação da análise discriminante pode ser precedida de estudos preparatórios que objetivam a seleção de um subconjunto de variáveis que contribuem efetivamente para a captação das diferenças entre os grupos e de estudos de suposição que garantam a adoção de técnicas apropriadas.

Sendo assim, preliminarmente à análise discriminante foi aplicado o processo de seleção de variáveis discriminantes realizado através do procedimento stepdisc do sistema SAS. 
O resultado deste procedimento é um subconjunto de variáveis que possam ser úteis na discriminação da observação entre as classes previamente determinadas.

Para este processamento optou-se pelo método stepwise que se fundamenta no nível de significância de um teste $\mathrm{F}$ de uma análise de covariância, aonde as variáveis já selecionadas agem como co-variáveis e a variável em estudo é a variável dependente. Além disto, considera a correlação parcial quadrada da variável em estudo nas classes, controlando para os efeitos das variáveis já selecionadas no modelo.

Preliminarmente à análise discriminante considerou-se a necessidade do atendimento à suposição de multinormalidade. Quando a distribuição é assumida como multinormal, recomenda-se a aplicação de um método paramétrico no desenvolvimento da função discriminante, também conhecida como critério de classificação que é determinada pela distância generalizada quadrada.

Para o teste de multinormalidade foram utilizados dois critérios: o de HENZEZIRKLER (HENZE; ZIRKLER, 1990) e o de MARDIA (MARDIA, 1974).

Quando é assumido que a distribuição não é multinormal métodos não-paramétricos foram usados para calcular as densidades específicas dos grupos. Neste caso optou-se pelo método k-nearest-neighbor (ROSEMBLATT, 1956; PARZEN, 1962 citados em SAS/STAT User's Guide, 1989) com função de densidade uniforme.

Finalmente, estatísticas multivariadas foram usadas para testar a existência de diferenças entre as classes estudadas. Especial atenção deve ser dada à distância generalizada pareada quadrada entre grupos, calculada de acordo com o descrito em eq. 9.

$$
D_{i, j}^{2}=\left(\bar{x}_{i}-\bar{x}_{j}\right)^{\prime} C O V^{-1}\left(\bar{x}_{i}-\bar{x}_{j}\right)
$$

Que permitiu avaliar o grau de similaridade entre os diversos grupos, inclusive com teste estatístico para avaliar sua nulidade em relação à distância de Mahalanobis. 

RESULTADOS E DISCUSSÃO

"Com tais pensamentos, diga-se de passagem, não pretendo em absoluto fornecer água para os moinhos dissonantes e rangentes dos nossos pessimistas cansados da vida; pelo contrário, deve ser expressamente notado que naquela época, quando a humanidade não se envergonhava ainda de sua crueldade, a vida na terra era mais contente do que agora que existem pessimistas".

NIETZSCHE

\subsection{Estratificação}

O processo de estratificação, apesar de preliminar para este estudo, acabou por revelar informações importantes em decorrência do processo de agrupamento empregado, com isto, resolveu-se considerá-lo como parte dos resultados e, com isto, também será apresentado e discutido.

"Numa perspectiva histórica, a ausência de uma definição clara e de um encaminhamento efetivo de uma política agrária pelas agências governamentais fez com que a implementação de assentamentos rurais no Estado de São Paulo, na grande maioria dos casos, tenha sido resultado das contundentes ações políticas dos trabalhadores rurais sem-terra, organizados em torno de diversos movimentos sociais e sindicais" (BERGAMASCO; NORDER, 2003).

Possivelmente, a ausência de uma política agrária claramente definida, tenha conduzido a uma ampla gama de situações no decorrer da história da reforma agrária do Estado de São Paulo, revelada no estudo de agrupamento que serviu como base para a estratificação dos assentamentos já que puderam ser determinados 16 grupos consistentemente heterogêneos.

"Vendo o tempo passar sem que qualquer solução tivesse sido aportada ao conflito, os trabalhadores fizeram saber às autoridades competentes que, na ausência de resposta, ocupariam as terras. É bom observar que as negociações foram conduzidas, de um lado, por agências 
58

governamentais envolvidas no conflito e, de outro, pelo sindicato enquanto representante dos bóias-frias" (COSTA, 2003).

Dentro de uma situação de pressão popular, é natural que os governantes optem por ações baseadas em princípios políticos e não técnicos, o que acaba por gerar uma ampla diversidade das condições.

Também as condições edafoclimáticas e o histórico de uso da terra têm influência direta sobre as realidades ambientais dos assentamentos, bem como a formação social e cultural dos assentados, pois "Como se sabe, a educação ambiental constitui uma arena, um espaço social que abriga uma diversidade de práticas de formação de sujeitos. A afirmação desta diversidade é produto da história social do campo educativo, onde concorrem diferentes atores, forças e projetos..." (CARVALHO, 2004), sendo natural a existência de uma diversidade cultural decorrente da formação diferencial promovida pela educação e, mais especificamente da educação ambiental.

Dentre os fatores que podem modificar a percepção ambiental dos assentados, o tempo pode ser um fator determinante já que somente a partir da década de 70 se iniciou um período de pressão ambientalista que fortaleceram as idéias de conservação e preservação ambiental e culminaram com a criação de mecanismos de controle do impacto ambiental na aprovação de projetos, na fiscalização de sua execução e na operação (TUCCI, 2004).

Com isto, a reforma agrária no Estado de São Paulo acaba por ser contemporânea do processo de firmação da pressão ambientalista já que "as primeiras propostas governamentais de realização de projetos de assentamento no Estado de São Paulo foram formuladas nos anos 60" (BERGAMASCO; NORDER, 2003). Se concomitantemente à criação de boa parte dos assentamentos da reforma agrária paulista há uma crescente pressão ambientalista, pode ser que esta pressão não seja exercida de maneira uniforme o que pode ter gerado diversidade nas opiniões e de concepções no desenvolvimento e na condução dos projetos.

A estratificação se alicerçou nos dados do levantamento promovido para avaliação da qualidade dos assentamentos da reforma agrária brasileira (SPAROVEK, 2002) e da listagem dos Projetos de Assentamento do Estado de São Paulo, apresentada na Tabela 1. 
Tabela 1 - Nomes dos projetos de assentamento do Estado de São Paulo em abril de 2005

\begin{tabular}{|c|c|c|}
\hline Nome do Assentamento & Nome do Assentamento & Nome do Assentamento \\
\hline Água Branca I & Marco II & Santa Cruz da Alcídia \\
\hline Água Limpa 1 & Maturi & Santa Edwiges \\
\hline Água Limpa 2 & Monjolo (Carlos Lamarca) & Santa Eudóxia \\
\hline Água Sumida & Monte Alegre 1 & Santa Isabel 1 \\
\hline Alcídia da Gata & Monte Alegre 2 & Santa Lúcia \\
\hline Alvorada & Monte Alegre 3 & Santa Maria \\
\hline Anhumas & Monte Alegre 4 & Santa Maria 2 \\
\hline Antonio Conselheiro & Monte Alegre 5 & Santa Rita \\
\hline Antonio Conselheiro II & Monte Alegre 6 & Santa Rita \\
\hline Araras 1 & Nossa Senhora Aparecida 1 & Santa Rita \\
\hline Araras 2 & Nossa Senhora Aparecida 2 & Santa Rita \\
\hline Araras 3 & Nossa Senhora Aparecida 3 & Santa Rita \\
\hline Araras 4 & Nova Conquista & Santa Rita da Serra \\
\hline Arco-Iris & Nova do Pontal & Santa Rita Pontal \\
\hline Areia Branca & Nova Esperança & Santa Rosa \\
\hline Aroeira & Nova Vida & Santa Rosa 1 \\
\hline Bebedouro (Reage Brasil) & Nova Vida (Rodeio) & Santa Terezinha da Água Sumida \\
\hline Bela Vista & Novo Horizonte & Santa Terezinha da Alcídia \\
\hline Bela Vista do Chibarro & Orlando Molina & Santa Vitória \\
\hline Belo Monte (São Sebastião) & Padre Josimo(São Pedro da Alcídia) & Santa Zélia \\
\hline Boa Sorte & Palu & Santana \\
\hline Bom Pastor & Paulo Freire & Santo Antonio \\
\hline Bonanza & Perdizes & Santo Antonio \\
\hline Bueno de Andrada & Pirituba II Área 1 & Santo Antonio 2 \\
\hline Cachoeira do Estreito & Pirituba II Área 2 & Santo Antonio Coqueiros \\
\hline Camaquã & Pirituba II Área 3 & Santo Antonio da Lagoa \\
\hline Canaã & Pirituba II Área 4 & Santo Antonio da Prata \\
\hline Capão Alto & Pirituba II Área 5 & Santo Antoniol \\
\hline Casa Branca & Pirituba II Área 6 & São Bento \\
\hline Che Guevara (Santa Clara) & Pirituba II Área 7 & São Francisco I (Cerrado) \\
\hline Chico Castro Alves & Pontal (Santa Rosa 2) & $\begin{array}{l}\text { São Francisco II (Bambu) } \\
\text { Palmares }\end{array}$ \\
\hline Cordeirópolis & Porto Feliz & São Joaquim \\
\hline Córrego Azul & Porto Letícia & São José 1 \\
\hline Córrego Rico & Porto Maria & São José 2 \\
\hline Engenho & Porto Velho & São José da Lagoa \\
\hline Esmeralda & Primavera & São Paulo \\
\hline Estrela D'Alva & Primavera 1 & São Pedro \\
\hline Flor Roxa & Primavera 2 & São Pedro \\
\hline Florestan Fernandes (São Jorge) & Promissãozinha & São Roque \\
\hline Formiga & Quatro Irmãs & Silvânia \\
\hline Fusquinha (Recanto do Porto X) & Radar & Sumaré 1 \\
\hline Gleba XV de Novembro & Rancho Alto & Sumaré 2 \\
\hline Guaná Mirim & Rancho Grande & Terra Livre \\
\hline Guarani & Repouso (Santo Antonio II) & Timboré \\
\hline Guarany & Reunidas & Tremembé \\
\hline Haidéia & Rio Paraná & Tucano \\
\hline
\end{tabular}


60

Tabela 1 - Nomes dos projetos de assentamento do Estado de. São Paulo em abril de 2005

(conclusão)

\begin{tabular}{|c|c|c|}
\hline Nome do Assentamento & Nome do Assentamento & Nome do Assentamento \\
\hline Haroldina & Rodeio & Tupanciretã \\
\hline Ibitiúva & Roseli Nunes (Nhancá) & Vale dos Sonhos \\
\hline Ipanema & Salvador & Vale Verde \\
\hline King Meat & Santa Adelaide & Vergel \\
\hline Lagoinha & Santa Angelina & Vista Alegre \\
\hline Laudenor de Souza (Porto Alcidia) & Santa Apolônia & Vô Tonico \\
\hline Lua Nova & Santa Carmem & Washington Luís \\
\hline Luis Moraes Neto (São Francisco) & Santa Cristina & Yapinary \\
\hline Malu & Santa Cruz & Zumbi dos Palmares \\
\hline
\end{tabular}

Fonte: Fundação Instituto de Terras do Estado de São Paulo "José Gomes da Silva"

Dentre os assentamentos listados, alguns não participaram deste estudo em função da inexistência de dados preliminares necessários para o processo de estratificação. Alguns deles porque foram criados posteriormente ao estudo que gerou os dados usados na estratificação.

Tabela 2 - Projetos de assentamento implantados após o levantamento de dados conduzido em 2002 para estudo da qualidade dos assentamentos da reforma agrária brasileira

\begin{tabular}{|c|c|c|c|c|}
\hline Nome & Município & Início & $\begin{array}{l}\text { Número } \\
\text { de lotes }\end{array}$ & $\begin{array}{l}\text { Área } \\
\text { (ha) }\end{array}$ \\
\hline Araras 4 & Araras & Julho/04 & 30 & 40,2 \\
\hline Belo Monte (São Sebastião) & Andradina & 2002 & 74 & 1534,5 \\
\hline Fusquinha (Recanto do Porto X) & Teodoro Sampaio & Setembro/03 & 43 & 1081,8 \\
\hline Luis Moraes Neto (São Francisco) & Caiuá & Agosto/03 & 72 & 1713,1 \\
\hline Malu & Caiuá & Março/03 & 24 & 477,1 \\
\hline Nossa Senhora Aparecida & Marabá Paulista & Setembro/03 & 17 & 616,10 \\
\hline Nova Vida & Iaras & Novembro/04 & 19 & 300,0 \\
\hline Padre Josimo (São Pedro da Alcídia) & Teodoro Sampaio & Julho/03 & 96 & 2290,2 \\
\hline Pirituba II Área 7 & Itaberá & Julho/04 & 8 & 42,5 \\
\hline Porto Maria & Rosana & Março/05 & 47 & 1127,1 \\
\hline Roseli Nunes (Nhancá) & $\begin{array}{l}\text { Mirante do } \\
\text { Paranapanema }\end{array}$ & Março/03 & 55 & 2082,7 \\
\hline Santa Edwiges & Teodoro Sampaio & Setembro/03 & 25 & 692,0 \\
\hline Santa Maria 2 & Marabá Paulista & Setembro/04 & 40 & 2703,0 \\
\hline Santa Rita & $\begin{array}{l}\text { São José dos } \\
\text { Campos }\end{array}$ & Setembro/02 & 64 & 446,92 \\
\hline Santo Antonio da Prata & Marabá Paulista & Abril/04 & 32 & 813,6 \\
\hline São Joaquim & Castilho & Janeiro/05 & 41 & 606,0 \\
\hline São Paulo & Presidente Epitácio & Agosto/03 & 76 & 1855,3 \\
\hline São Pedro & Marabá Paulista & Abril/04 & 6 & 261,5 \\
\hline São Roque & Franco da Rocha & Novembro/03 & 66 & 619,2 \\
\hline Terra Livre & Castilho & Janeiro/05 & 41 & 628,3 \\
\hline Vista Alegre & Caiuá & Fevereiro/02 & 22 & 532,8 \\
\hline Total & & & 898 & 20463,8 \\
\hline
\end{tabular}

Fonte: Fundação Instituto de Terras do Estado de São Paulo "José Gomes da Silva" 
Além da ausência de dados preliminares, necessários para o processo de estratificação a inclusão dos assentamentos listados na Tabela 2 requereria cuidados adicionais já que são assentamentos muito recentes, os quais podem registrar influências específicas para esta situação.

Seriam acrescentadas variações imponderáveis neste momento, fruto da recentidade do processo de implantação do assentamento e das indefinições inerentes a processos de acomodação.

Outro conjunto de Projetos de Assentamento também não foi observado no estudo preliminar e, por isto, também não entraram no processo de estratificação e amostragem.

Tabela 3 - Projetos de assentamento não usados no processo de estratificação e amostragem

\begin{tabular}{|c|c|c|c|c|}
\hline Nome & Município & Início & $\begin{array}{l}\text { Número } \\
\text { de lotes }\end{array}$ & $\begin{array}{l}\text { Área } \\
\text { (ha) }\end{array}$ \\
\hline Água Limpa 1 & Presidente Bernardes & Setembro/96 & 31 & 956,0 \\
\hline Orlando Molina & Muritinga do Sul & Julho/99 & 77 & 1529,0 \\
\hline Palu & Presidente Bernardes & Setembro/96 & 44 & 1243,9 \\
\hline Pontal (Santa Rosa 2) & $\begin{array}{l}\text { Mirante do } \\
\text { Paranapanema }\end{array}$ & Junho/96 & 13 & 232,0 \\
\hline Repouso (Santo Antonio II) & $\begin{array}{l}\text { Mirante do } \\
\text { Paranapanema }\end{array}$ & Outubro/00 & 21 & 515,1 \\
\hline Rio Paraná & Castilho & Setembro/90 & 92 & 2208,7 \\
\hline Rodeio & Presidente Bernardes & Março/97 & 65 & 1861,4 \\
\hline Santa Angelina & Caiuá & Fevereiro/02 & 23 & 535,8 \\
\hline Santa Terezinha da Água Sumida & Teodoro Sampaio & Julho/99 & 48 & 1345,8 \\
\hline São Francisco II - Palmares & Presidente Alves & Outubro/99 & 31 & 846,4 \\
\hline Timboré & Andradina & Setembro/92 & 176 & 3364,7 \\
\hline Total & & & 621 & 14638,7 \\
\hline
\end{tabular}

Fonte: Fundação Instituto de Terras do Estado de São Paulo "José Gomes da Silva"

Uma vez definida a abrangência do estudo, buscou-se contemplar toda a variabilidade dos assentamentos relatados através de variáveis que conduziram ao Índice de qualidade do meio Ambiente (QA) (SPAROVEK, 2002). O índice calculado para os Projetos de Assentamento de todo o Brasil, inclusive os de São Paulo foi desenvolvido a partir das seguintes informações: Área de preservação permanente, Área de reserva legal, Extrativismo ilegal, Erosão e Melhoria Ambiental.

Sendo assim, definiu-se que a estratificação seria feita com base nos dados apresentados na Tabela 4. 
62

Tabela 4 - Identificação das questões formuladas, temas abordados e campos para registro em software para armazenamento de dados usadas na análise de agrupamento, base para a estratificação dos assentamentos do Estado de São Paulo

\begin{tabular}{clcc}
\hline Questão & & \multicolumn{1}{c}{ Tema } & Campo \\
\cline { 1 - 1 } 81 & & \% de área de preservação permanente preservada & 332 \\
82 & & \% de reserva legal preservada & 336 \\
83 & & Famílias: extração de madeira/floresta & 340 \\
84 & & Famílias que caçam/capturam para venda & 344 \\
85 & & Área degradada por erosão & 348 \\
86 & & Área degradada por salinização & 352 \\
88 & & Área com melhoria ambiental & 360 \\
87 & Área desmatada após criação do PA & 356 \\
\hline
\end{tabular}

Fonte: Universidade de São Paulo - USP; Ministério do Desenvolvimento Agrário - MDA; Food ans Agriculture Organization of the United Nations -FAO) in: SPAROVEK, G. A qualidade dos assentamentos da reforma agrária brasileira, 2002.

A partir destes dados e da aplicação da análise de agrupamento que permite a criação de grupos homogêneos, base para uma amostragem estratificada.

Em função da grande variabilidade e do grande número de projetos de assentamento, optou-se por fragmentar a análise de forma que em um primeiro estágio, foram separados 5 grupos, conforme apresentado na Tabela 5.

Tabela 5 - Assentamentos agrupados no primeiro estágio da estratificação em função da uniformidade das medidas ambientais avaliadas através de Cluster Analisys usando o método average

\begin{tabular}{|c|c|c|c|}
\hline Grupo & Nome do Assentamento & Município & $\begin{array}{l}\text { Número de } \\
\text { Lotes }\end{array}$ \\
\hline \multirow[t]{2}{*}{1} & Gleba XV de Novembro & Euclides da Cunha/Rosana & 571 \\
\hline & Primavera 2 & Presidente Venceslau & 42 \\
\hline \multirow[t]{2}{*}{2} & Santa Lúcia & Mirante do Paranapanema & 24 \\
\hline & Santo Antonio & Marabá Paulista & 73 \\
\hline \multirow[t]{4}{*}{3} & King Meat & Mirante do Paranapanema & 46 \\
\hline & Marco II & Mirante do Paranapanema & 9 \\
\hline & Santa Rita & Caiuá & 21 \\
\hline & Santo Antonio 2 & Presidente Bernardes & 24 \\
\hline 4 & Primavera & Andradina & 210 \\
\hline 5 & Reunidas & Promissão & 629 \\
\hline
\end{tabular}

A formação dos grupos que receberam números de 1 a 5 pode ser explicada com base nas características médias das medidas usadas. 


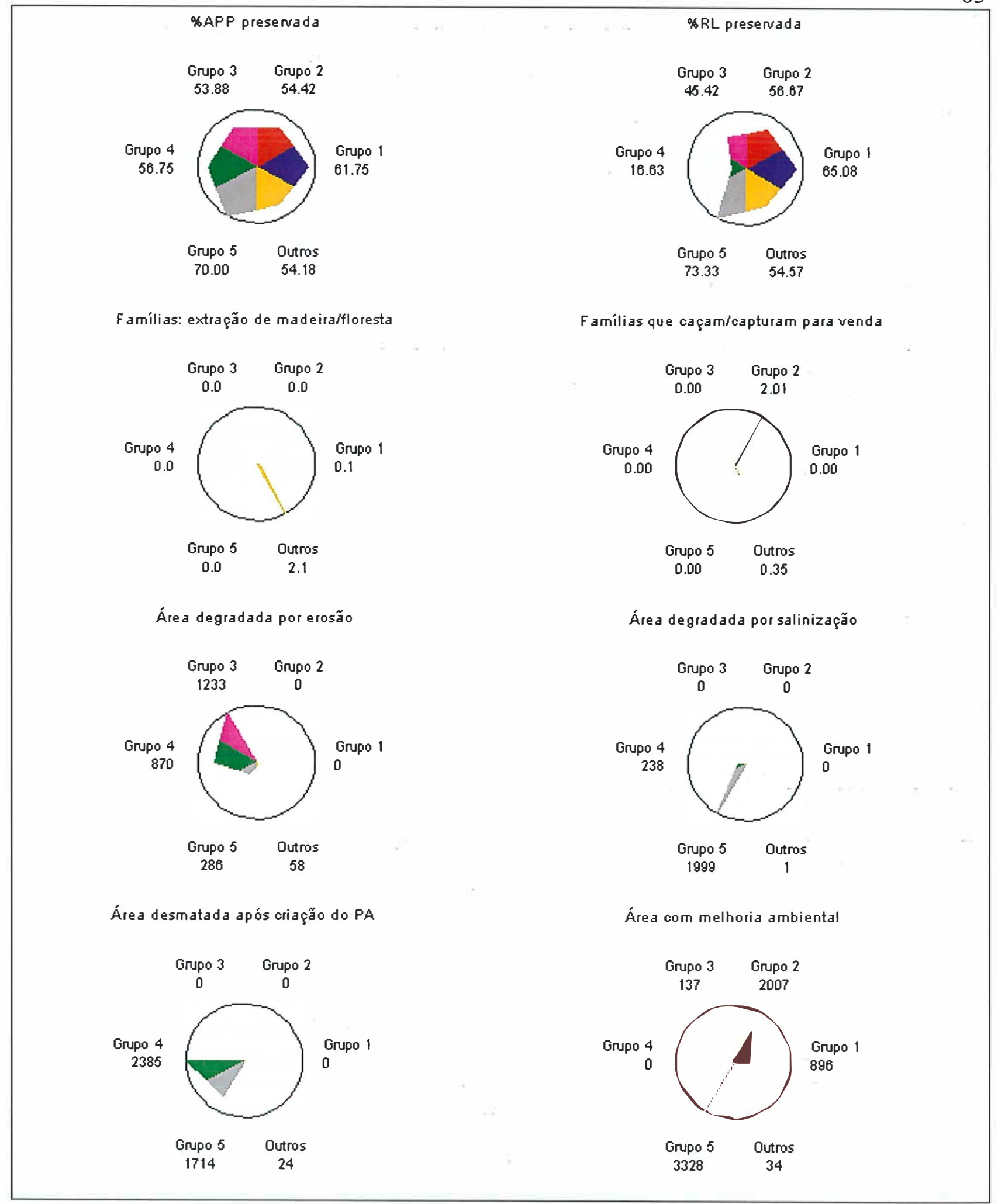

Figura 3 - Características médias das medidas ambientais utilizadas na primeira fase da estratificação dos assentamentos do Estado de São Paulo em cada grupo formado 
$\mathrm{Na}$ análise destaca-se inicialmente o assentamento Reunidas, com valores médios altos em diversas características ambientais dentre as quais se destacam a maior porcentagem de APP preservada (70\%), maior porcentagem de Reserva Legal Preservada $(73,33 \%)$ e maior porcentagem de Área com melhoria ambiental (3328 ha). Também a área degradada por salinização (1999 ha) é a maior dentre as médias dos grupos desta etapa. Tudo isto faz deste um assentamento muito diferente de todos os demais e, por isto o seu isolamento no que foi chamado de Grupo 5.

A experiência de campo trouxe forte corroboração da singularidade deste assentamento, primeiramente em decorrência de seu tamanho já que congrega uma população que, no ano de 1991, representava em torno de $10 \%$ da população total do Município de Promissão e 63\% da população rural (BERGAMASCO;NORDER, 2003).

O segundo assentamento que se mostra díspar é o Primavera, onde são relacionadas porcentagens altas de preservação de APP $(56,75 \%)$, porém, dentre todos, a mais baixa taxa de preservação da Reserva Legal (16,63\%). Este assentamento também é o que apresenta maior área desmatada após a implantação do assentamento (2385 ha), maior apenas que o Reunidas (1714 ha). Também é o que apresenta maior quantidade de área degradada pela erosão 870 ha, mas que é inferior à média do grupo 3. Isto justifica o isolamento do assentamento Primavera no que foi batizado de Grupo 4.

O Grupo 3, possivelmente, tem sua segregação associada à área degradada por erosão já que em relação às outras medidas ele não difere tanto dos grupos 1 e 2 . $O$ grupo 3,formado pelos assentamentos Marco II, Santa Rita do Caiuá, Santo Antonio II e King Meat são os que apresentam maiores áreas médias degradadas por erosão.

De forma similar, o grupo 2 tem uma medida como determinante da união por semelhança dos assentamentos Santa Lúcia e Santo Antônio e esta medida é a alta freqüência relativa de caçalcaptura de animais para venda. O grupo 1 , por fim, é diferente dos demais grupos por não apresentar salinização, caçalcaptura de animais para venda, erosão ou extração de madeira para venda. Uma vez identificados os assentamentos mais discrepantes e a eles atribuídos números de grupos que servirão como base para a amostragem estratificada proposta, um novo estágio da análise de agrupamento foi conduzida com os assentamentos até então englobados no que seria um grupo 6 , Tabela 6 . 
Tabela 6 - Assentamentos agrupados no segundo estágio da estratificação em função da uniformidade das medidas ambientais avaliadas através de Cluster Analisys usando o método average

\begin{tabular}{|c|c|c|c|}
\hline Grupo & Nome do Assentamento & Município & $\begin{array}{l}\text { Número de } \\
\text { Lotes }\end{array}$ \\
\hline \multirow[t]{3}{*}{6} & Bela Vista & Iperó & 31 \\
\hline & Pirituba II Área 2 & Itaberá & 55 \\
\hline & Tremembé & Tremembé & 97 \\
\hline \multirow[t]{8}{*}{7} & Alvorada & Mirante do Paranapanema & 21 \\
\hline & Antonio Conselheiro & Mirante do Paranapanema & 65 \\
\hline & Boa Sorte & Restinga & 159 \\
\hline & Guarani & Pradópolis & 273 \\
\hline & Perdizes & Colômbia & 41 \\
\hline & Radar & Presidente Venceslau & 29 \\
\hline & São Pedro & Rancharia & 74 \\
\hline & Zumbi dos Palmares & Iaras & 52 \\
\hline \multirow[t]{3}{*}{8} & Água Sumida & Teodoro Sampaio & 121 \\
\hline & Nova do Pontal & Rosana & 123 \\
\hline & Santa Rita & Tupi Paulista & 31 \\
\hline 9 & Flor Roxa & Mirante do Paranapanema & 39 \\
\hline 10 & Monte Alegre 3 & Araraquara & 76 \\
\hline
\end{tabular}

A listagem permite a observação de um grupo formado fora das regiões noroeste e oeste do Estado de São Paulo. Até a primeira fase somente assentamentos destas áreas haviam sido agrupados. O grupo 6, por sua vez, congrega dados de outras regiões. Apesar da maior concentrações de assentamentos na região oeste, sobretudo na Região do Pontal do Paranapanema, os assentamentos Bela Vista, Pirituba - Área 2 e Tremembé se agrupam através de características comuns captadas no estudo sobre preservação ambiental previamente conduzido.

O Grupo 7 apresenta uma abrangência territorial muito grande por reunir assentamentos dispersos por todo o Estado de São Paulo, ao passo que o Grupo 8 reúne assentamentos da região do Pontal do Paranapanema. Por fim, os assentamentos Flor Roxa e Monte Alegre 3 são os mais discrepantes não tendo se reunido a nenhum dos outros assentamentos dentro dos limites de distância propostos para a análise de agrupamento os quais foram selecionados pela estatística Pseudo- $\mathrm{t}^{2}$. 


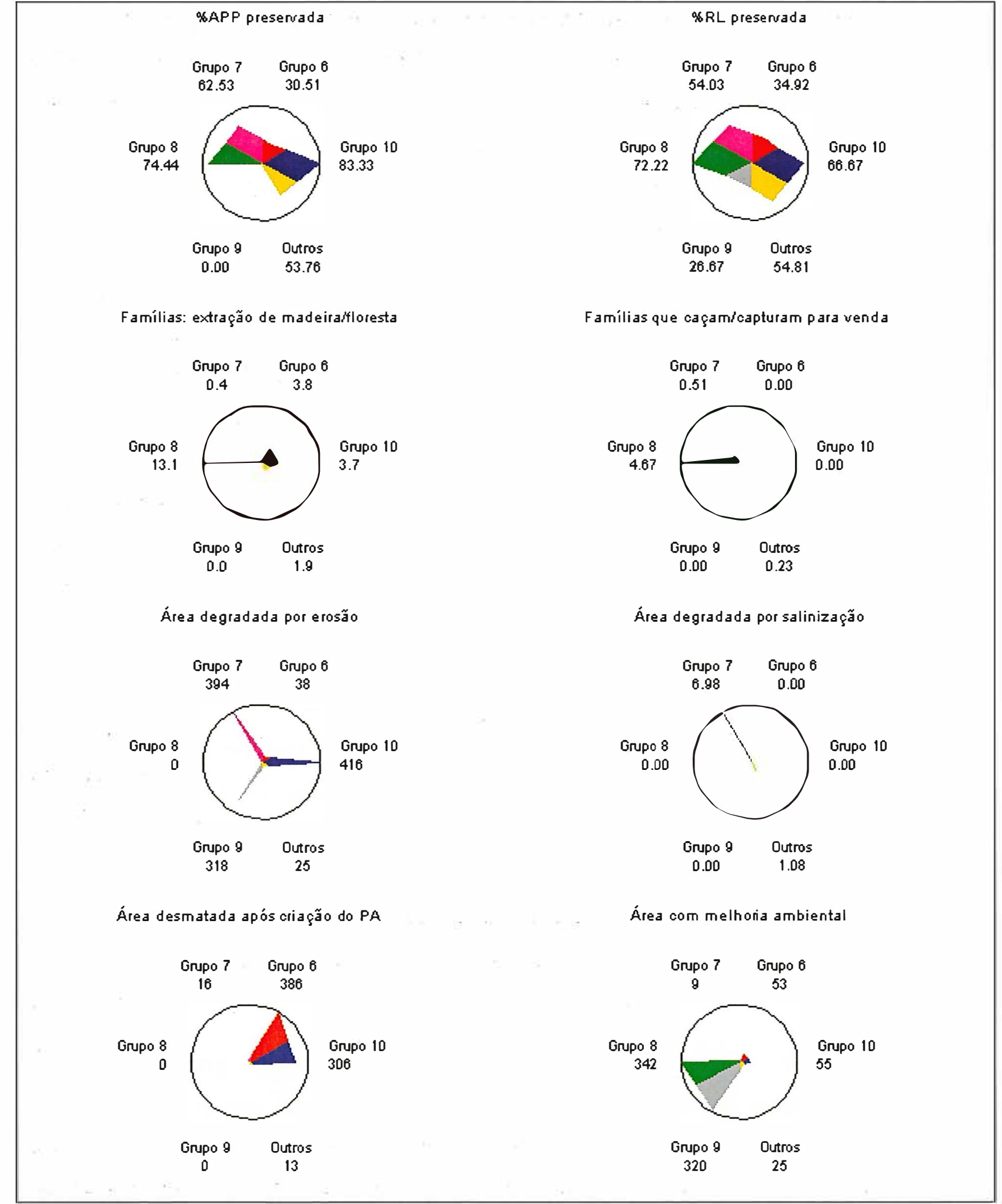

Figura 4 - Características médias das medidas ambientais utilizadas na primeira fase da estratificação dos assentamentos do Estado de São Paulo em cada grupo formado 
A análise dos dados ambientais sugere que o assentamento Monte Alegre 3 (Grupo 10) é diferente dos demais que permaneceram na análise em função das altas porcentagens de APP e RL preservadas associada a expressivas áreas degradadas por erosão (416 ha). A determinação do grupo através destas três variáveis também ocorre no Grupo 3 do primeiro estágio de agrupamento. Ocorre, todavia, que as porcentagens de preservação eram inferiores ao passo que a área degradada pela erosão, superiores o que justifica a segregação.

O grupo 9 se destaca dos demais pela inexistência $(0,0 \%)$ de APP preservada o que pode ser decorrente da inexistência de áreas que justifiquem o seu estabelecimento ou da supressão da mata destas áreas. Pode-se observar também, a maior área de melhoria ambiental deste grupo (320ha), somente inferior às de grupos formados no primeiro estágio. Supõe-se que esteja ocorrendo um processo de recomposição das áreas de preservação 320 ha corresponde a $33,55 \%$ da área total do assentamento. Há também, grande área degradada pela erosão 318 ha. A inexistência de extração de madeira, de caçalcaptura de animais ou de área desmatada após a implantação do assentamento é coerente com o quadro geral e conduz à idéia da implantação do assentamento em área de grande passivo ambiental.

O Grupo 8 que congrega os assentamentos Água Sumida, Nova do Pontal e Santa Rita I, que além de grandes porcentagens de áreas de APP e RL preservadas também têm altos índices de extração de madeira e caçalcaptura de animais. Este é o primeiro grupo onde se verificam estes itens em proporções notáveis. Há também, grande área com melhoria ambiental (342 ha), o mais alto dentre os assentamentos desta etapa.

O grupo 7 formado pelos assentamentos Radar, Alvorada, Palmares, Perdizes, São Pedro, Antonio Conselheiro, Guarani, Zumbi dos Palmares, Fazenda Esmeralda e Horto Boa Sorte se agrupam em função, de pequenas áreas degradadas por salinização que totalizam 6,98 ha em média e por erosão que totalizam 394 ha em média. Nos outros quesitos estes assentamentos não são tão diferentes dos demais.

Por fim, o Grupo 6 integrado pelos assentamentos Tremembé, Horto Bela Vista e Pirituba - Área 2 reúne assentamentos que apresentam, até agora, as menores porcentagens de APP e RL preservadas associadas com a maior média de área desmatada neste grupo, somente inferiores às médias observadas nos Grupos 4 (Primavera) e 5 (Reunidas). 
Concluindo a fase de estratificação, uma terceira etapa de agrupamentos foi conduzida, tendo sido excluídos, todos os que já foram agrupados o que permite salientar as diferenças dentro deste grupo. Os resultados são apresentados na Tabela 7.

Tabela 7 - Assentamentos agrupados no terceiro estágio da estratificação

\begin{tabular}{|c|c|c|c|}
\hline Grupo & Nome do Assentamento & Município & $\begin{array}{l}\text { Número de } \\
\text { Lotes }\end{array}$ \\
\hline \multirow[t]{3}{*}{11} & Engenho & Presidente Epitácio & 27 \\
\hline & Monte Alegre 2 & Motuca & 62 \\
\hline & São Bento & Mirante do Paranapanema & 183 \\
\hline \multirow[t]{4}{*}{12} & Aroeira & Guaracaí & 40 \\
\hline & Bueno de Andrada & Araraquara & 31 \\
\hline & Nova Conquista & Rancharia & 125 \\
\hline & Silvânia & Matão & 19 \\
\hline \multirow[t]{8}{*}{13} & Antonio Conselheiro II & Guarantã & 151 \\
\hline & Arco-Íris & Mirante do Paranapanema & 105 \\
\hline & Bela Vista do Chibarro & Araraquara & 176 \\
\hline & Bom Pastor & Sandovalina & 130 \\
\hline & Bonanza & Rosana & 31 \\
\hline & Che Guevara (Santa Clara) & Mirante do Paranapanema & 46 \\
\hline & Esmeralda & Pereira Barreto & 85 \\
\hline & Haidéia & Teodoro Sampaio & 27 \\
\hline & Ipanema & Iperó & 151 \\
\hline & Paulo Freire & Mirante do Paranapanema & 62 \\
\hline & Pirituba II Área 3 & Itaberá & 73 \\
\hline & Santa Adelaide & Avaré & 23 \\
\hline & Santa Vitória & Teodoro Sampaio & 27 \\
\hline & Santa Zélia & Teodoro Sampaio & 104 \\
\hline & Belo Monte & Andradina & 74 \\
\hline \multirow[t]{2}{*}{14} & Água Branca I & Teodoro Sampaio & 29 \\
\hline & Água Limpa 2 & Presidente Bernardes & 26 \\
\hline & Alcídia da Gata & Teodoro Sampaio & 18 \\
\hline & Anhumas & Castilho & 63 \\
\hline & Araras 1 & Araras & 6 \\
\hline & Araras 2 & Araras & 14 \\
\hline & Araras 3 & Araras & 46 \\
\hline & Areia Branca & Marabá Paulista & 87 \\
\hline & Cachoeira do Estreito & Teodoro Sampaio & 29 \\
\hline & Camaquã & Ipeúna & 47 \\
\hline & Canaã & Mirante do Paranapanema & 55 \\
\hline & Monjolo (Carlos Lamarca) & Itapetininga & 41 \\
\hline
\end{tabular}


Tabela 7 - Assentamentos agrupados no terceiro estágio da estratificação

\begin{tabular}{|c|c|c|c|c|}
\hline Grupo & Nome do Assentamento & Município & & $\begin{array}{c}\text { Número de } \\
\text { Lotes }\end{array}$ \\
\hline \multirow[t]{43}{*}{14} & Casa Branca & Casa Branca & & 24 \\
\hline & Chico Castro Alves & Martinópolis & & 87 \\
\hline & Cordeirópolis & Cordeirópolis & & 21 \\
\hline & Córrego Azul & Teodoro Sampaio & & 9 \\
\hline & Estrela D'Alva & Mirante do Paranapanema & & 31 \\
\hline & Florestan Fernandes & & & \\
\hline & (São Jorge) & Presidente Bernardes & & 55 \\
\hline & Guaná Mirim & Euclides da Cunha & & 34 \\
\hline & Guarany & Sandovalina & & 68 \\
\hline & Haroldina & Mirante do Paranapanema & & 71 \\
\hline & Capão Alto & Itapetininga & & 18 \\
\hline & Lagoinha & Presidente Epitácio & & 150 \\
\hline & Laudenor de Souza & & & \\
\hline & (Porto Alcídia) & Teodoro Sampaio & & 60 \\
\hline & Lua Nova & Mirante do Paranapanema & & 17 \\
\hline & Maturi & Caiuá & & 172 \\
\hline & Monte Alegre 1 & Motuca & & 49 \\
\hline & Monte Alegre 5 & Motuca & & 34 \\
\hline & Monte Alegre 6 & Araraquara & & 88 \\
\hline & Nossa Senhora Aparecida & Mirante do Paranapanema & & 9 \\
\hline & Nossa Senhora Aparecida & Pirajuí & & 7 \\
\hline & Nova Vida (Rodeio) & Martinópolis & & 37 \\
\hline & Novo Horizonte & Mirante do Paranapanema & & 57 \\
\hline & Pirituba II Área 1 & Itapeva & & 105 \\
\hline & Pirituba II Área 4 & Itaberá & & 51 \\
\hline & Pirituba II Área 5 & Itaberá & & 39 \\
\hline & Pirituba II Área 6 & Itapeva & & 52 \\
\hline & Porto Feliz & Porto Feliz & & 83 \\
\hline & Porto Letícia & Euclides da Cunha & & 36 \\
\hline & Porto Velho & Presidente Epitácio & & 65 \\
\hline & Promissãozinha & Promissão & & 8 \\
\hline & Quatro Irmãs & Presidente Bernardes & & 15 \\
\hline & Rancho Alto & Euclides da Cunha & & 50 \\
\hline & Rancho Grande & Euclides da Cunha & & 101 \\
\hline & Santa Apolônia & Mirante do Paranapanema & & 104 \\
\hline & Santa Cristina & Mirante do Paranapanema & & 35 \\
\hline & Santa Cruz & Mirante do Paranapanema & & 17 \\
\hline & Santa Cruz da Alcídia & Teodoro Sampaio & & 25 \\
\hline & Santa Eudóxia & Presidente Bernardes & & 6 \\
\hline & Santa Isabel 1 & Mirante do Paranapanema & & 70 \\
\hline & Santa Maria & Presidente Venceslau & & 17 \\
\hline & Santa Rita & Piquerobi & & 26 \\
\hline & Santa Rita & Turmalina/Populina & & 19 \\
\hline
\end{tabular}


70

Tabela 7 - Assentamentos agrupados no terceiro estágio da estratificação

(conclusão)

\begin{tabular}{|c|c|c|c|}
\hline Grupo & Nome do Assentamento & Município & $\begin{array}{l}\text { Número de } \\
\text { Lotes }\end{array}$ \\
\hline \multirow[t]{21}{*}{14} & Santa Rita da Serra & Teodoro Sampaio & 40 \\
\hline & Santa Rita Pontal & Euclides da Cunha & 51 \\
\hline & Santa Rosa & Euclides da Cunha & 65 \\
\hline & Santa Rosa 1 & Mirante do Paranapanema & 24 \\
\hline & Santana & Mirante do Paranapanema & 12 \\
\hline & Santo Antonio 1 & Mirante do Paranapanema & 17 \\
\hline & Santo Antonio da Lagoa & Piquerobi & 29 \\
\hline & Santo Antonio Coqueiros & Teodoro Sampaio & 23 \\
\hline & São José 1 & Birigüi & 48 \\
\hline & São José 2 & Guaracaí & 39 \\
\hline & São José da Lagoa & Piquerobi & 29 \\
\hline & Sumaré 1 & Sumaré & 26 \\
\hline & Sumaré 2 & Sumaré & 39 \\
\hline & Tucano & Euclides da Cunha & 35 \\
\hline & Tupanciretã & Presidente Venceslau & 78 \\
\hline & Vale dos Sonhos & Mirante do Paranapanema & 23 \\
\hline & Vale Verde & Teodoro Sampaio & 50 \\
\hline & Vergel & Mogi Mirim & 90 \\
\hline & Vô Tonico & Teodoro Sampaio & 19 \\
\hline & Washington Luís & Mirante do Paranapanema & 16 \\
\hline & Yapinary & Ribeirão dos Índios & 40 \\
\hline \multirow[t]{10}{*}{15} & Córrego Rico & Jaboticabal & 47 \\
\hline & Formiga & Colômbia & 61 \\
\hline & Ibitiúva & Pitangueiras & 43 \\
\hline & Monte Alegre 4 & Motuca & 49 \\
\hline & Nova Esperança & Euclides da Cunha & 98 \\
\hline & Primavera 1 & Presidente Venceslau & 82 \\
\hline & Bebedouro (Reage Brasil) & Bebedouro & 82 \\
\hline & Salvador & Brejo Alegre & 20 \\
\hline & Santa Terezinha da Alcídia & Teodoro Sampaio & 26 \\
\hline & São Francisco I (Cerrado) & Presidente Alves & 28 \\
\hline 16 & Santa Carmem & Mirante do Paranapanema & 37 \\
\hline
\end{tabular}

Nesta última etapa, então, foram compostos os últimos assentamentos de um total de 16. Conforme pode ser verificado, o Grupo 14 ficou sendo o que congrega um maior número de assentamentos, entretanto, após todo o processo de classificação empreendido, supõe-se que o grupo seja suficientemente homogêneo para que se possa tratá-lo como um único estrato. 


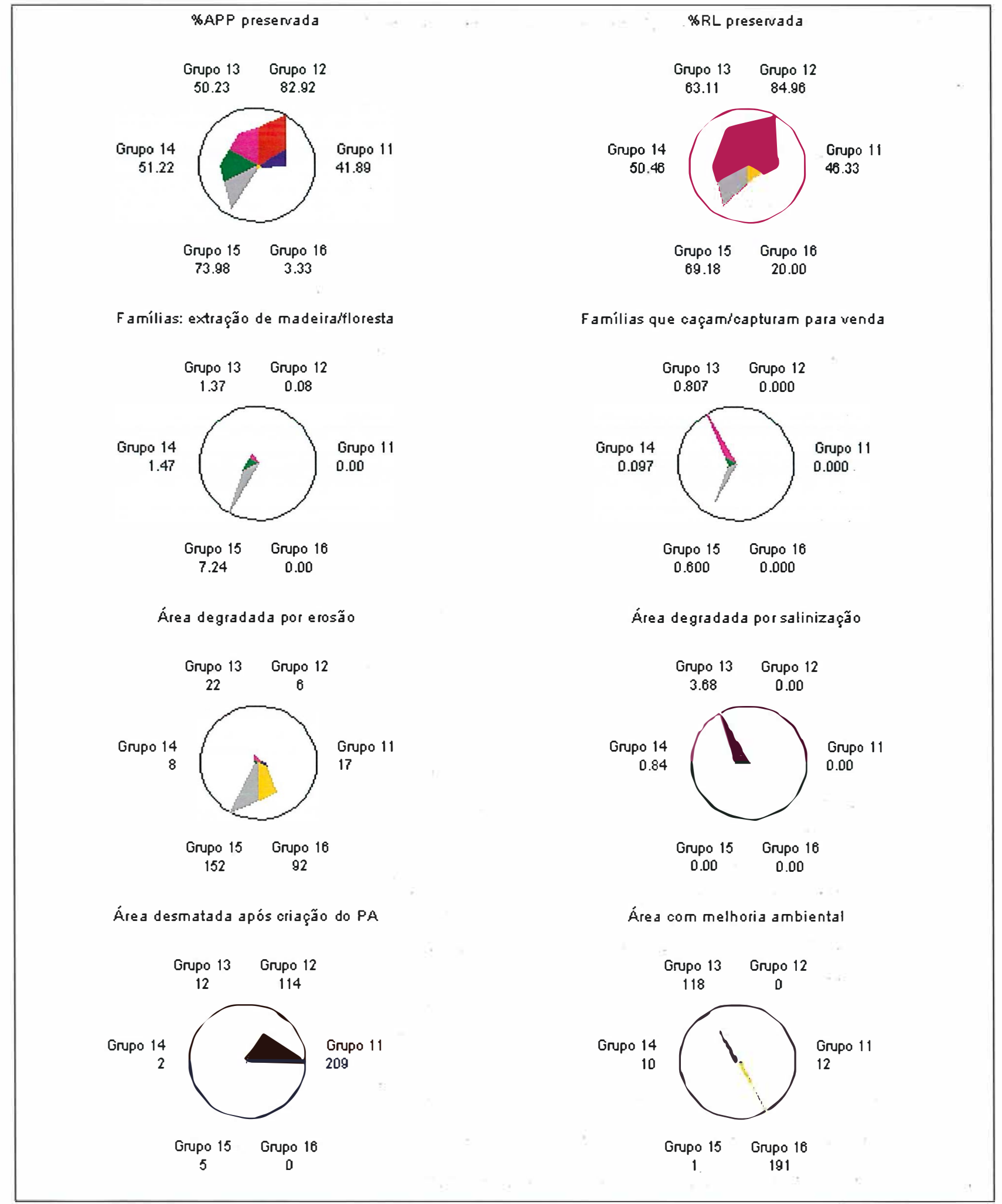

Figura 5- Características médias das medidas ambientais utilizadas na primeira fase da estratificação dos assentamentos do Estado de São Paulo 
O grupo 11, formado pelos assentamentos São Bento, Monte Alegre 2 e Engenho se caracterizam primeiramente por uma quantidade média de porcentagens de APP e RL preservadas, associados a uma média de desmatamento após a implantação do assentamento de 209 ha. Dos assentamentos que restaram para esta etapa esta é a maior média de desmatamento observada, embora muito inferior à anteriores.

O grupo 12, formado pelos assentamentos Aroeira, Bueno de Andrada, Nova Conquista e Silvânia se destacam pelas maiores porcentagens de áreas de APP e RL preservadas e ainda de maneira similar ao Grupo 10 teve áreas desmatadas após a implantação do projeto de assentamento. O que difere estes dois grupos é a menor área degradada por erosão no Grupo 12 (6 ha) contra 416 ha de áreas degradadas por erosão no Grupo 10.

O Grupo 13 congrega assentamentos com porcentagens médias de APP e RL preservadas, mas que apresentam famílias que caçam elou capturam animais para venda e ainda, uma pequena média de área degradada por salinização. Este grupo também se destaca pelo relato da existência de 118 ha de áreas com melhoria ambiental.

O Grupo 14, mais numeroso de todos, congrega assentamentos que indicam um comportamento relacionado a cerca de $50 \%$ de áreas de APP e RL preservados e inexistência de nenhuma das demais características avaliadas.

O Grupo 15, por sua vez é formado pelos assentamentos com altas porcentagens de APP e RL preservadas: 73,98 \% e 69,17\%, respectivamente, associadas à existência de caça, extração de madeira e área degradada por erosão.

Por fim, o Grupo 16 (assentamento Santa Carmem) é caracterizado por baixas porcentagens de APP e RL preservadas somado a 92 ha de área degradada por erosão e por 191 ha onde foram implantadas melhorias ambientais.

É deste cenário que se partiu para um processo de amostragem dentro de cada grupo de forma que se captassem as informações relacionadas à percepção ambiental através de entrevistas com o apoio de um questionário semi-estruturado.

As características dos grupos são sintetizadas na Figura 6. 


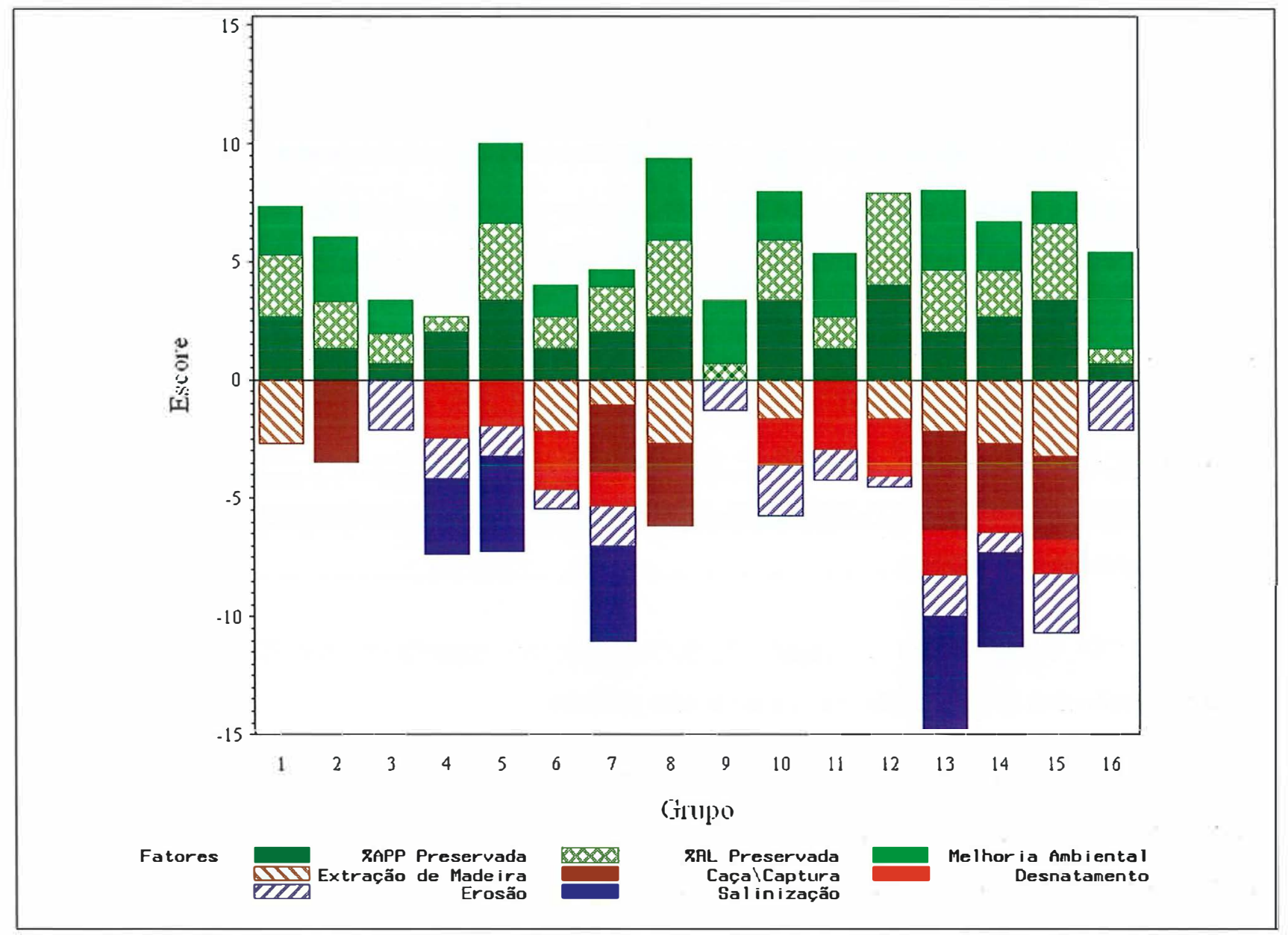

Figura 6 - Efeito dos postos das características na composição dos estratos que embasaram a amostragem

O grupo 9 (assentamento Flor Roxa) se caracteriza pela menor quantidade de itens que o fazem distinto de todos os demais assentamentos. Negativo, nele, encontramos o problema da erosão e de positivo a influência, sobretudo da área de melhoria ambiental associado à presença de reserva legal preservada. Muito similar a ele, na região do Pontal do Paranapanema pode ser citado o assentamento Santa Carmem (Grupo 16), que mantém os mesmos critérios de agrupamento, acrescido da existência de APP preservada.

Também o Grupo 3 (King Meat, Marco II, Santa Rita e Santo Antonio 2) é distinto pelos mesmos fatores, exceto pela menor quantidade de melhorias ambientais implementadas. Do ponto de fatores negativos, todos eles contam com áreas degradadas por erosão. 
Diferentes destes onde há poucos efeitos detectados dentro dos índices de qualidade ambientais, o grupo 14 conta com uma maior influência de um conjunto de efeitos positivos e negativos que se somam, mas que, em geral são menores que os dos demais grupos.

Podem ser observadas as principais características que determinam o agrupamento dos assentamentos e o que legitima a estratificação. A abordagem multivariada se mostra satisfatória na estratificação dos dados ambientais já que foram formados grupos claramente diversos em relação às características ambientais estudadas.

Provoca um certo estranhamento a presença de área degradada por salinização e isto aparece em 5 grupos $(4,5,7,13$ e 14). A interpretação, todavia, deve levar em conta que por ser um fato raro, ele determina a existência de diferenças entre os grupos, daí sua grande importância da determinação dos grupos.

$\mathrm{Na}$ interpretação da Figura 6, barras maiores significam que são importantes na discriminação dos grupos e não que as áreas são grandes.

\subsection{Número de lotes de cada assentamento}

Além de representar os diversos grupos, também há a preocupação de se captar a variabilidade existente dentro dos assentamentos. A aplicação de um único questionário, por exemplo, não seria suficiente para se compreender o que ocorre no assentamento todo, por isto, preocupou-se também com a determinação de uma amostragem que garanta a representatividade do assentamento.

A aquisição de dados através do questionário principia com o cálculo do número de questionários que deveria ser aplicado em cada um dos projetos de assentamento para se garantir, também, a representatividade dos dados em relação à população de cada assentamento previamente selecionado para composição dos grupos, Tabela 8. 
Tabela 8 - Contabilidade da aplicação de questionários de acordo com o delineamento amostral. Tamanho da amostra calculado para intervalo de confiança de $20 \%$, nível de significância de $5 \%$ e o tamanho da população é o número de lotes de cada assentamento

\begin{tabular}{|c|c|c|c|c|}
\hline Grupo & Nome do Assentamento & $\begin{array}{l}\text { Número de } \\
\text { Lotes }\end{array}$ & $\begin{array}{l}\text { Tamanho da } \\
\text { Amostra }\end{array}$ & $\begin{array}{l}\text { Questionários } \\
\text { Aplicados } \\
\end{array}$ \\
\hline 1 & Gleba XV de Novembro & 571 & 23 & 22 \\
\hline 2 & Santa Lúcia & 24 & 12 & 9 \\
\hline \multirow[t]{2}{*}{3} & Marco II & 9 & 7 & 5 \\
\hline & Santa Rita & 21 & 11 & 11 \\
\hline 4 & Primavera & 210 & 22 & 17 \\
\hline 5 & Reunidas & 629 & 23 & 23 \\
\hline \multirow[t]{2}{*}{6} & Pirituba II Área 2 & 55 & 17 & 19 \\
\hline & Tremembé & 97 & 19 & 19 \\
\hline \multirow[t]{3}{*}{7} & Boa Sorte & 159 & 21 & 22 \\
\hline & Guarani & 273 & 22 & 23 \\
\hline & Zumbi dos Palmares & 52 & 17 & 17 \\
\hline \multirow[t]{2}{*}{8} & Água Sumida & 121 & 20 & 22 \\
\hline & Santa Rita & 31 & 14 & 15 \\
\hline 9 & Flor Roxa & 39 & 15 & 19 \\
\hline 10 & Monte Alegre 3 & 76 & 18 & 14 \\
\hline \multirow{2}{*}{11} & Engenho & 27 & 13 & 13 \\
\hline & Monte Alegre 2 & 62 & 18 & 14 \\
\hline \multirow[t]{2}{*}{12} & Bueno de Andrada & 31 & 14 & 15 \\
\hline & Silvânia & 19 & 11 & 11 \\
\hline \multirow[t]{4}{*}{13} & Antonio Conselheiro II & 151 & 21 & 20 \\
\hline & Esmeralda & 85 & 19 & 19 \\
\hline & Ipanema & 151 & 21 & 0 \\
\hline & Pirituba II Área 3 & 73 & 18 & 14 \\
\hline \multirow[t]{12}{*}{14} & Camaquã & 47 & 16 & 15 \\
\hline & Capão Alto & 18 & 11 & 10 \\
\hline & Chico Castro Alves & 87 & 19 & 18 \\
\hline & Estrela D'Alva & 31 & 14 & 16 \\
\hline & Haroldina & 71 & 18 & 13 \\
\hline & Nova Vida (Rodeio) & 37 & 15 & 15 \\
\hline & Pirituba II Área 1 & 105 & 20 & 24 \\
\hline & Santa Isabel 1 & 70 & 18 & 6 \\
\hline & Santa Rosa 1 & 24 & 12 & 12 \\
\hline & Santo Antonio Coqueiros & 23 & 12 & 8 \\
\hline & São José 1 & 48 & 16 & 15 \\
\hline & Sumaré 1 & 26 & 13 & 14 \\
\hline \multirow[t]{4}{*}{15} & Córrego Rico & 47 & 16 & 15 \\
\hline & Monte Alegre 4 & 49 & 16 & 17 \\
\hline & Nova Esperança & 98 & 19 & 23 \\
\hline & Santa Terezinha da Alcídia & 26 & 13 & 13 \\
\hline \multirow[t]{2}{*}{16} & Santa Carmem & 37 & 15 & 15 \\
\hline & Total & 3810 & 659 & 612 \\
\hline
\end{tabular}


Em 12 assentamentos (Flor Roxa, Pirituba II - Área 1, Nova Esperança, Pirituba II Área 2, Água Sumida, Estrela D'alva, Boa Sorte, Guarani, Santa Rita, Bueno de Andrada, Sumaré I e Monte Alegre 4) foram aplicados mais questionários que o planejado; entretanto, o número não é exageradamente maior a ponto de se super-dimensionar a importância do assentamento pois, no máximo, foram coletados 4 questionários a mais que o planejado em 3 assentamentos (Flor Roxa, Pirituba II-Área l e Nova Esperança).

Em 11 assentamentos ateve-se ao número de lotes planejado (Santa Rita, Reunidas, Tremembé, Zumbi dos Palmares, Engenho, Silvânia, Esmeralda, Nova Vida (Rodeio), Santa Rosa 1, Santa Terezinha da Alcídia e Santa Carmem.

Em 17 assentamentos não foi possível coletar o número de questionários planejado tendo faltado um questionário em 7 assentamentos (Gleba XV de Novembro, Antonio Conselheiro II, Camaquã, Capão Alto, Chico Castro Alves, São José 1, Córrego Rico); entre 2 e 5 questionários em 8 assentamentos (Marco II, Santa Lúcia, Monte Alegre 3, Monte Alegre 2, Pirituba - Área 3, Santo Antonio dos Coqueiros, Primavera e Haroldina). No assentamento Santa Isabel 1 faltou a aplicação de 12 questionários e no assentamento Ipanema não foi possível a aplicação de nenhum questionário em função da limitação do tempo.

A apresentação do número de questionários aplicados por assentamento visa permitir a avaliação da legitimidade da amostra uma vez que ela quantifica o efetivo contato com um número significativo de assentados em cada um dos assentamentos selecionados. No ponto de vista da pesquisa, todavia, é mais importante a totalização de questionários dentro de cada um dos estratos definidos através do processo anteriormente descrito.

Em função do acoplamento deste estudo a outras pesquisas e de problemas tais como a não clara delimitação dos assentamentos de uma mesma área, e mesmo da substituição de assentamentos previamente sorteados e que se encontravam em difícil condição de acesso, por outros de mesmo grupo 10 assentamentos não selecionados no processo de amostragem foram incorporados posteriormente à pesquisa, Tabela 9. 
Tabela 9 - Assentamentos não selecionados preliminarmente e que participaram do projeto de pesquisa

\begin{tabular}{|c|c|c|c|c|}
\hline Grupo & Nome do Assentamento & $\begin{array}{l}\text { Número de } \\
\text { Lotes }\end{array}$ & $\begin{array}{l}\text { Tamanho da } \\
\text { Amostra }\end{array}$ & $\begin{array}{l}\text { Questionários } \\
\text { Aplicados }\end{array}$ \\
\hline 11 & São Bento & 183 & 21 & 7 \\
\hline \multirow{2}{*}{13} & Haidéia & 27 & 13 & 6 \\
\hline & Santa Vitória & 27 & 13 & 6 \\
\hline \multirow[t]{3}{*}{14} & Vale Verde & 50 & 16 & 11 \\
\hline & Pirituba II - Área 4 & 51 & 17 & 18 \\
\hline & Pirituba II - Área 5 & 39 & 15 & 14 \\
\hline & Pirituba II - Área 6 & 52 & 17 & 7 \\
\hline & Cachoeira do Estreito & 29 & 13 & 2 \\
\hline & Santa Rita da Serra & 40 & 15 & $:$ \\
\hline 9 & Vista Alegre & 31 & 12 & 3 \\
\hline
\end{tabular}

Uma vez incorporados, os questionários contribuíram para uma maior aderência à proposta inicial, sobretudo para a representatividade dentro de cada um dos estratos, Tabela 10.

Tabela 10 - Contabilidade do número de questionários planejados e efetivamente aplicados dentro dos estratos

\begin{tabular}{|c|c|c|c|}
\hline Grupo & Planejado & Aplicado & Porcentagem (\%) \\
\hline 1 & 23 & 22 & 96 \\
\hline 2 & 12 & 9 & .75 \\
\hline 3 & 18 & 16 & 89 \\
\hline 4 & 22 & 17 & 77 \\
\hline 5 & 23 & 23 & 100 \\
\hline 6 & 36 & 38 & 106 \\
\hline 7 & 60 & 62 & 103 \\
\hline 8 & 34 & 37 & 109 \\
\hline 9 & 15 & 22 & 147 \\
\hline 10 & 18 & 14 & 78 \\
\hline 11 & 31 & 33 & 106 \\
\hline 12 & 25 & 26 & 104 \\
\hline 13 & 79 & 65 & 82 \\
\hline 14 & 184 & 222 & 121 \\
\hline 15 & 64 & 68 & 106 \\
\hline 16 & 15 & 15 & 100 \\
\hline Total & 659 & 689 & 105 \\
\hline
\end{tabular}

Considerando-se a proposta inicial foram assumidos como válidos os números de questionários aplicados e a representatividade desejada. 


\subsection{Representatividade do Estado de São Paulo}

Em vista da escala proposta para esta pesquisa, foi calculado o intervalo de confiança (COCHRAN, 1977) a partir do número efetivo de questionários aplicados, usando-se como parâmetros um nível de confiança de $95 \%$, o tamanho da amostra de 689, tamanho da população 9423 (número de lotes) o que resultou em um intervalo de confiança de 3,59\%.

Sendo assim, as porcentagens apresentadas apresentam uma margem de erro de $3,59 \%$, para mais ou para menos, um valor bastante tolerável para a maioria dos casos.

\subsection{Caracterização do entrevistado}

Inicialmente o foram descritas as informações pertinentes à pessoa que se dispôs a ser ouvido na entrevista (entrevistado). Informações sobre os entrevistados se revestem de importância à medida que na abordagem preliminar à entrevista, foi solicitado que a pessoa responsável pela tomada de decisões no lote se dispusesse a responder.

Características demográficas, sociais ou econômicas entre os produtores, se relevantes ao seu comportamento devem refletir diferenças em suas crenças (BARTHOLO JÚNIOR; BURSZTYN, 2001) e, por conseguinte em sua percepção.

\subsubsection{Caracterização do entrevistado quando à titularidade do lote}

Inicialmente, perguntou-se se o entrevistado era o titular do lote, Figura 7.

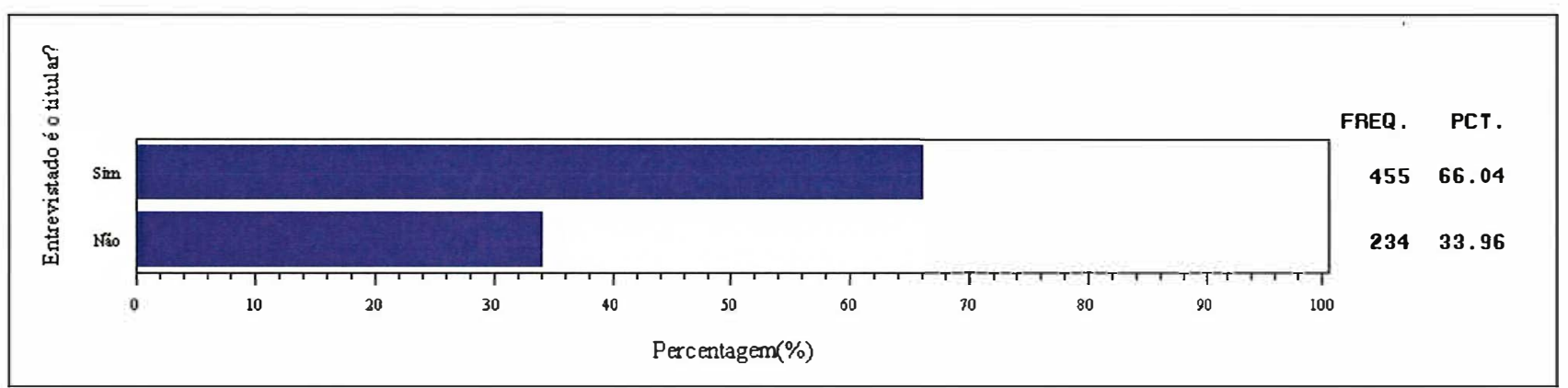

Figura 7 - Qualificação do entrevistado diante da titularidade do lote $\left(\chi^{2}: 70,89\right.$; G.L.: 1; valor-p:<0,0001)

Há fortes indícios de que a proporção de titulares responsáveis pelas decisões nos lotes é superior à de não titulares que se apresentaram como "tomadores de decisão". Há casos onde isto não ocorre e foram testemunhadas situações de pessoas que se aposentaram, deixando o lote por conta de seus filhos, foram observadas situações nas quais a mulher era a titular, porém 
os homens se apresentaram para responder o questionário e também o inverso, mulheres assumindo a posição de tomadoras de decisão mesmo quando os companheiros eram os titulares.

Foram detectadas, também, situações de co-participação na tomada de decisão, inclusive com o compartilhamento do questionário entre diversas pessoas, tendo cada uma a maior autoridade dentro de uma das áreas de conhecimento abordadas.

Existem consideráveis diferenças no gerenciamento do ambiente natural nas diferentes unidades familiares. O que acontece em uma propriedade específica é dependente de fatores psicológicos do proprietário da terra em questão (MACDOWELL, 1989). Disto decorre, provavelmente o fato de que a maior parte dos questionários foram respondidos por seus proprietários (titulares), mas por outro lado, quando o proprietário não era o tomador de decisão, foi delegada a outro, a responsabilidade pelo fornecimento de dados.

\subsubsection{Caracterização do entrevistado quanto ao gênero}

Tendo havido anteriormente o comentário de que homens se apresentaram para responder a questão quando suas esposas eram titulares, uma segunda questão que se formalizou é a do gênero do entrevistado, Figura 8.

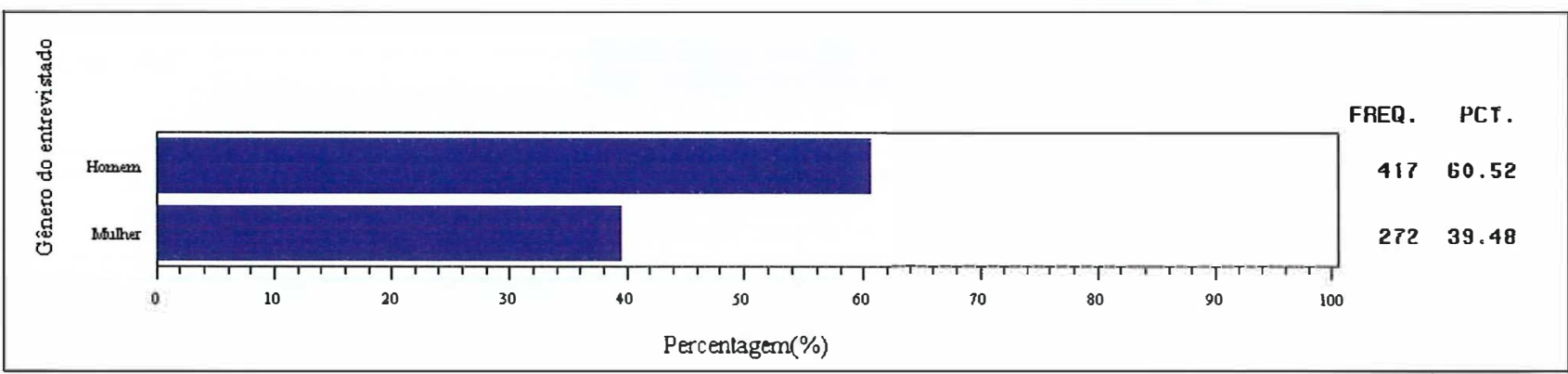

Figura 8 - Qualificação do gênero do entrevistado diante da titularidade do lote $\left(\chi^{2}: 30,51\right.$; G.L.: 1; valor-p: $<0,0001$ )

Foram detectados fortes indícios $(\mathrm{p}<0,0001)$ de que o gênero homem é, na maior parte das vezes, responsável pelas decisões, entretanto, a participação feminina no processo não é desprezível já que uma proporção muito grande de lotes teve a mulher se apresentando como responsável pelas decisões. No Estado de Pernambuco, no ano de 1990, a atuação de mulheres economicamente ativas totalizava $73,83 \%$ na produção agrícola sendo que $25,86 \%$ eram produtoras agropecuárias autônomas (OMETTO; HOFFMANN; ALVES, 1999). 
A diversidade da estrutura ocupacional paulista em 1981 implica na necessidade do uso de 27 ocupações para abarcar aproximadamente $60 \%$ dos trabalhadores do sexo masculino. Destas, apenas 4 integram um contingente apreciável de mulheres e entre estas se inclui a de trabalhadores da agropecuária, que ocupa 4,72\% da População Economicamente Ativa (PEA) Feminina em 1981 e 3\% em 1990 (OMETTO; HOFFMANN; ALVES, 1997), daí explicada a grande participação feminina no processo de produção agrícola. Se considerada, ainda, a natureza familiar dos assentamentos, eram esperadas as proporções indicadas.

No ano de 1990 a importância das mulheres no preenchimento das tarefas classificadas como masculinas: ocupações nas quais a porcentagem de homens é maior, cai em função do aumento de mulheres que passaram a ocupar o cargo de motoristas (OMETTO; HOFFMANN; ALVES, 1997).

\subsubsection{Caracterização do entrevistado quando à escolaridade}

Outra preocupação diz respeito à relação entre o papel de "tomador de decisão" e a escolaridade, Figura 9.

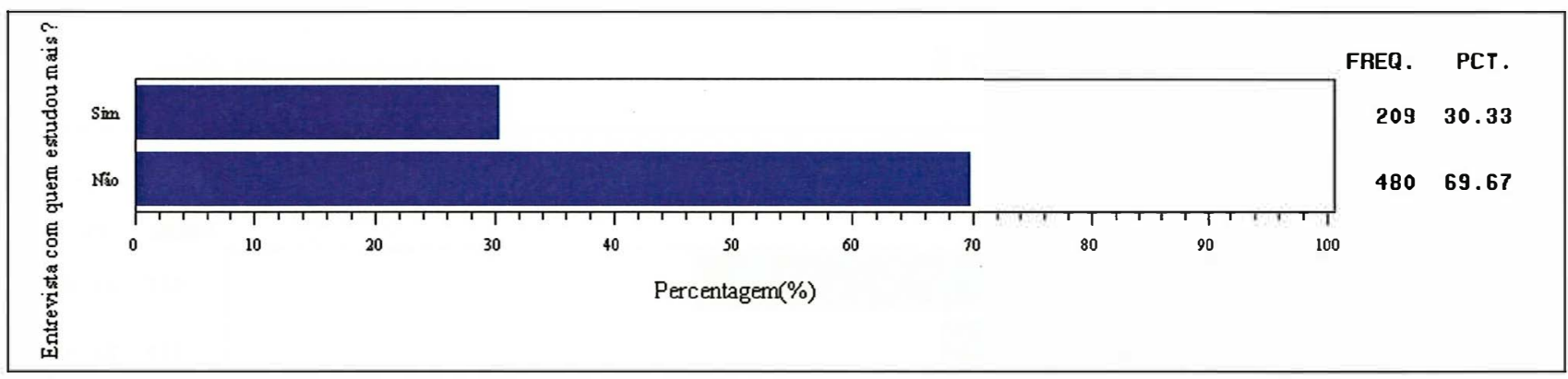

Figura 9 - Qualificação da escolaridade diante do papel de tomador de decisão dentro do lote do assentamento $\left(\chi^{2}: 106,59 ;\right.$ G.L.: 1 ; valor-p:<0,0001)

Foram detectados fortes indícios $(\mathrm{p}<0,0001)$ de que a escolaridade não é entendida como importante para as tomadas de decisão já que na maior parte dos casos, o entrevistado não era a pessoa do lote com maior escolaridade.

Não é clara a associação entre a "tomada de decisão" e a maior escolaridade, pois na maior parte das vezes $(69,67 \% \pm 3,59 \%)$ a entrevista não foi feita com a pessoa que mais estudou no lote. 
Isto é um problema porque "é clara a correlação positiva entre o nível educacional e a conservação ambiental" (MACDOWELL, 1989). Neste caso, todavia, a maior parte das entrevistas foram feitas com pessoas com escolaridade muito baixa, o que pode mascarar o efeito do nível educacional sobre a percepção ambiental.

A educação, apesar de poder ser uma faca de dois gumes ao aumentar o interesse por processos naturais e por abrir a porta para a aplicação de tecnologias mais complicadas (MACDOWELL, 1989), possivelmente não se vislumbre no cenário em que a maior educação não esteja associada a uma maior responsabilidade e, portanto, a um maior peso nas decisões de produção agrícola.

\subsection{Análise descritiva de parâmetros sociais}

A introdução de uma série de perguntas de cunho social no questionário objetivou a criação de um arcabouço que norteie e que, posteriormente, possam ser usados como fatores determinantes de comportamentos diferenciais frente às questões ambientais.

\subsubsection{Caracterização do entrevistado quanto à época de chegada à região do assentamento}

Dentro deste contexto se analisa a época de chegada do assentado à região de sua propriedade em relação à data de criação do assentamento, Figura 10.

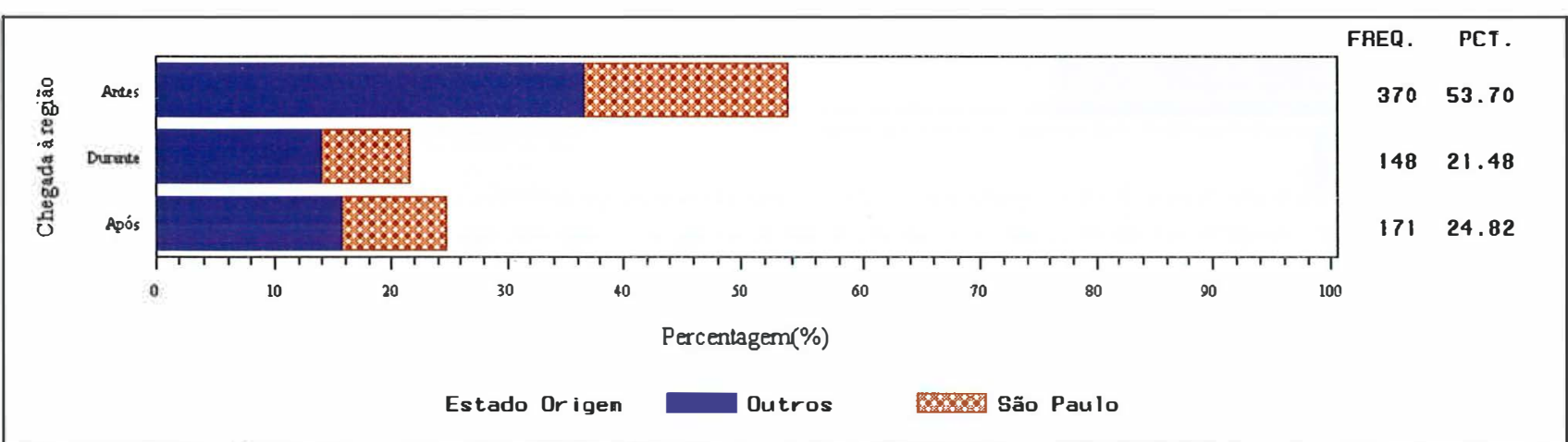

Figura 10 - Época de chegada à região em relação ao estabelecimento do assentamento e unidade da federação de origem do assentado de $\left(\chi^{2}: 129,77\right.$; G.L.: 2 ; valor$\mathrm{p}:<0,0001)$

São observados fortes indícios $(\mathrm{p}<0,001)$ de que a maioria dos assentados chegou à região do assentamento, antes de sua criação. Não há muita diferença entre os que chegam durante e após a implantação do assentamento. Pode-se verificar que grande parte dos assentados são migrantes vindos de outras unidades da federação e que sua chegada precede a implantação 
82

do assentamento o que não nos oferece sinais de que o motivo da migração seja a reforma agrária, mas sim a busca por outros recursos não disponíveis em suas localidades de origem.

Em função da proposta de se sustentar através da atividade agrícola, há que se supor que grande parte destes assentados tenha o passado ligado a esta atividade, e destaca-se a execução de trabalhos agrícolas como empregados de fazendas.

A migração interna ao Estado não pode ser corretamente avaliada em função de não se ter registrado a ligação de cidades dentro do Estado já que proporções consideráveis das migrações intra-estaduais ocorreram para cidades vizinhas o que caracterizaria uma migração puramente burocrática.

\subsubsection{Caracterização lote quanto ao número de moradores}

Uma outra característica importante é o número de moradores no lote, Figura 11.

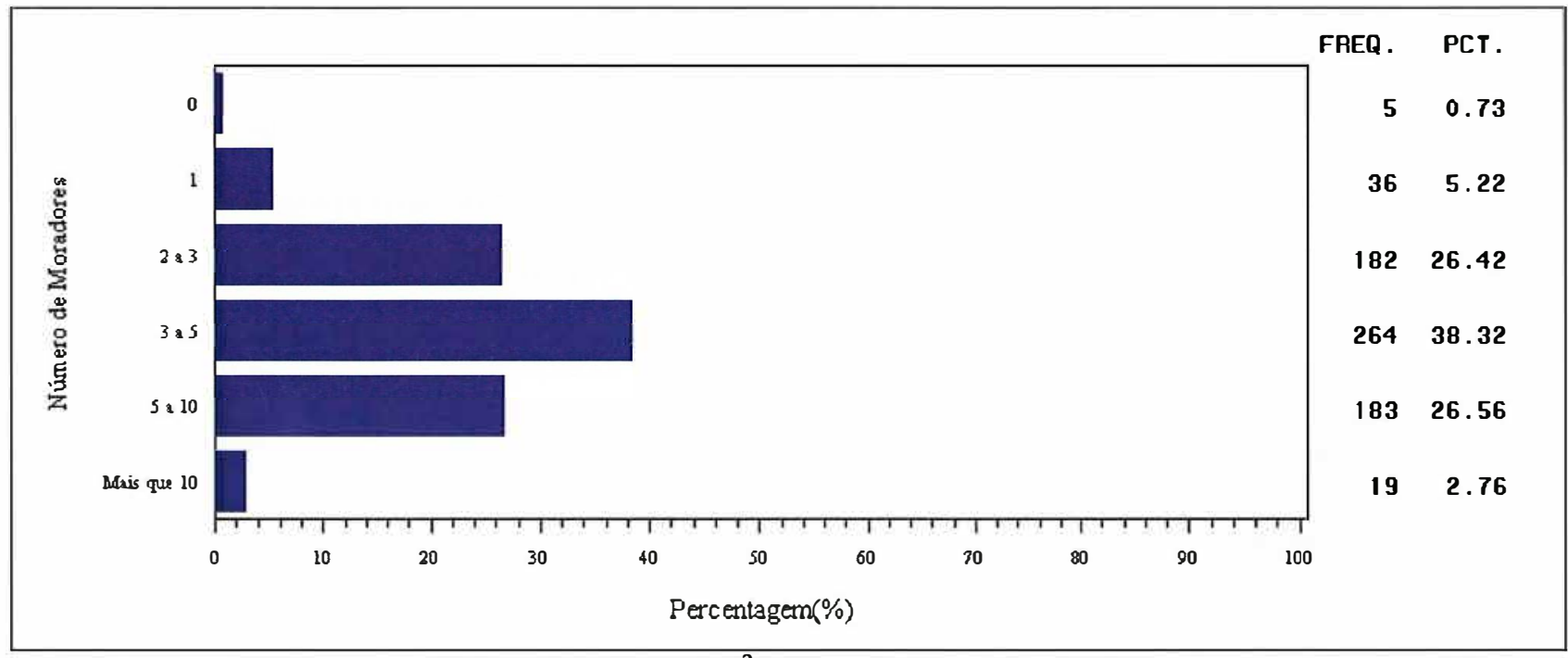

Figura 11 - Número de moradores no lote $\left(\chi^{2}: 512,66 ;\right.$ G.L.: 5 ; valor-p:<0,0001)

Observa-se inicialmente que são muito raros os casos de assentados que moram fora do assentamento ( $<1$ pessoa morando no lote). Poucos são os que moram sozinhos $(5,22 \% \pm$ $3,59 \%$ ) que, se somados aos lotes com mais de 10 pessoas, perfazem uma porcentagem bastante baixa do total.

Lotes com mais de 10 moradores são bastante raros e, na maioria das vezes, resultam da aglutinação de diversas famílias, inclusive com casas, economias e atividades distintas. 


\subsubsection{Caracterização lote quanto ao número de trabalhadores}

Além do número de moradores, também assume importância considerável o número de pessoas que trabalham no lote, Figura 12.

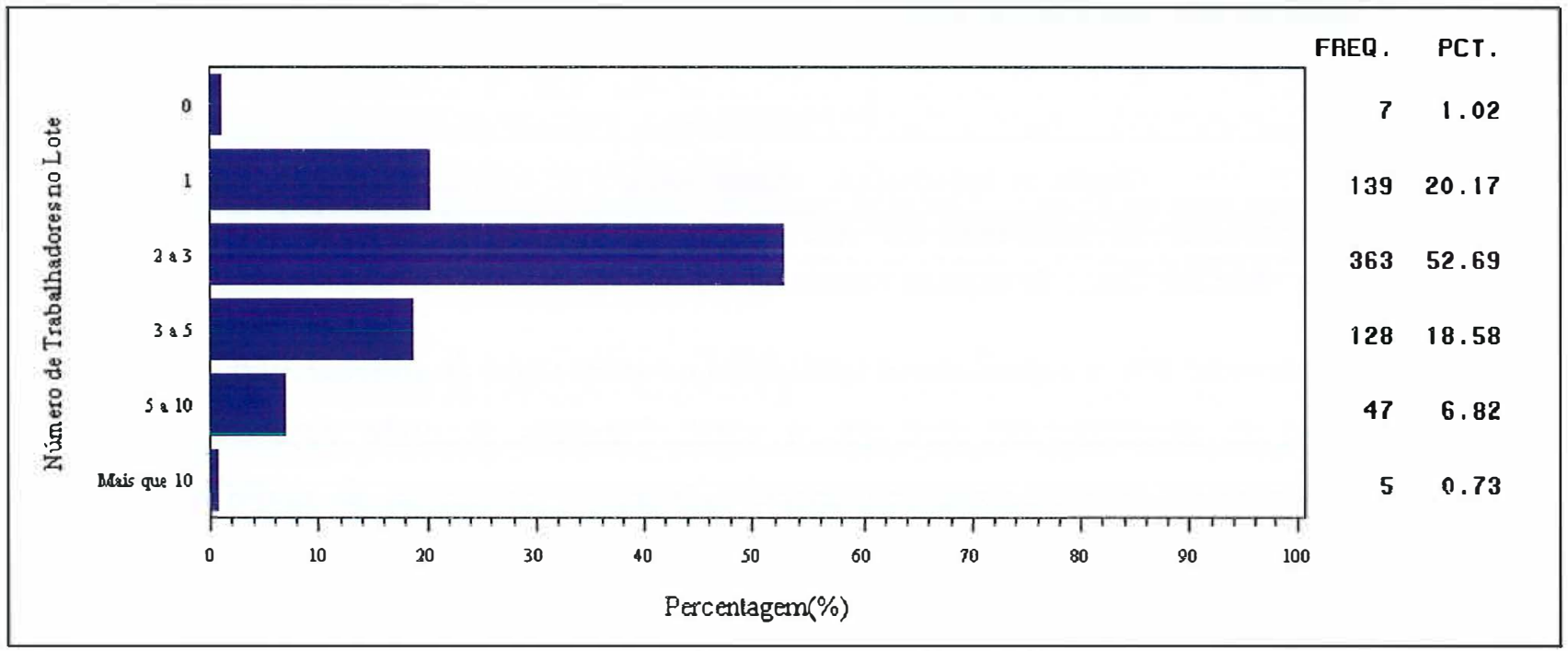

Figura 12 - Número de pessoas que trabalham no lote $(\chi 2: 789,29 ;$ G.L.: 5 ; valor-p:<0,0001)

Também é significativa a diferença na proporção de trabalhadores. Em relação ao histograma de moradores, pode ser observado um deslocamento, segundo o qual a maior parte dos lotes que contam com 3 a 5 moradores passam a contar com 2 a 3 pessoas que desenvolvem atividades no lote.

Dois são os fatores que justificam este deslocamento entre o número de moradores e o número de trabalhadores. Inicialmente, a presença de crianças que não são consideradas como trabalhadoras no lote, pelo menos até certa idade, necessária para compreender e desempenhar atividades produtivas.

Um segundo fator são os filhos e demais moradores que desenvolvem atividades nas cidades próximas ao assentamento ou mesmo na área rural. Tal efeito se verifica, na prática da entrevista, em um número grande de casos, sobretudo quando os filhos constituem sua própria família e o lote agrícola não é suficiente para prover o sustento a tantas pessoas.

\subsubsection{Caracterização do entrevistado quanto a sua qualidade de vida}

Uma questão social importante diz respeito à satisfação com a vida no assentamento, Figura 13. 


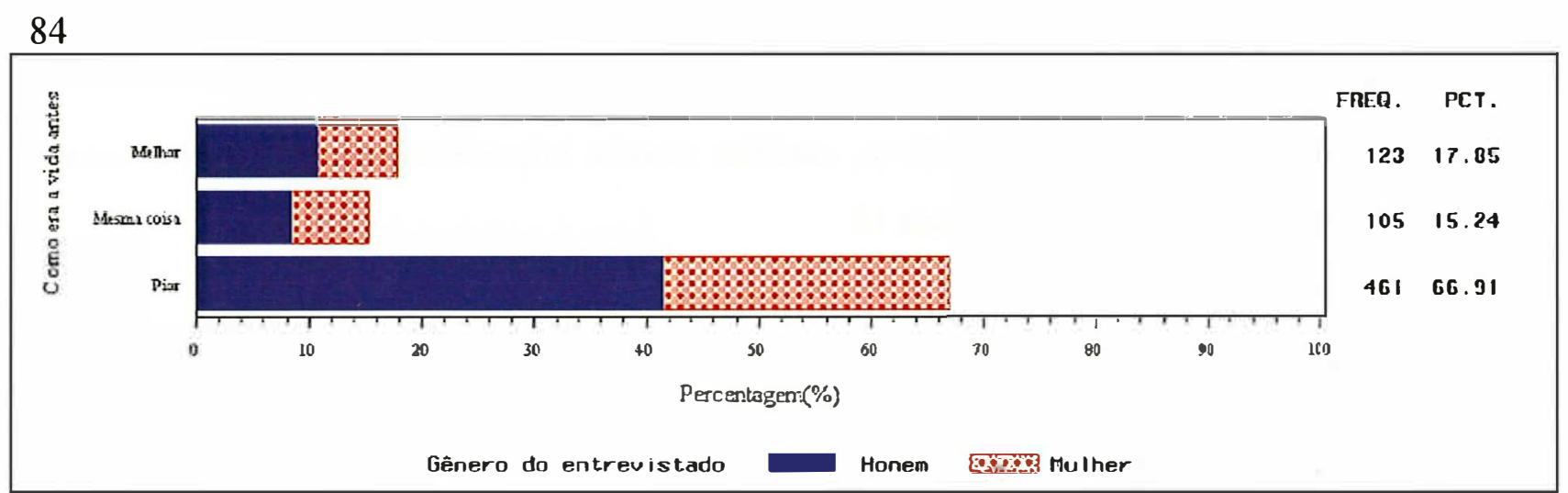

Figura 13 - Percepção da qualidade de vida antes, em relação à que tem no assentamento $\left(\chi^{2}: 350,22 ;\right.$ G.L.: 2 ; valor-p:<0,0001)

Observa-se que é significativa $(\mathrm{p}<0,0001)$ a proporção de pessoas que consideram a vida anterior à do assentamento pior que a atual. Também se pôde observar que não é significativa (valor-p: 0,4585) a associação entre o gênero e a percepção da qualidade de vida o que não permite inferir que entrevistados de gêneros diferentes tenham opiniões divergentes em relação a esta questão.

Também na região de Araraquara pôde-se perceber que a grande maioria dos agricultores entrevistados (84\%) prefere viver na área rural, $11 \%$ moram na agrovila e 5\% (correspondente a um entrevistado) reside na cidade (STRACHMAN; TAMBELINI, 2004), tal proporção observada na região de Araraquara, se confirma na atual pesquisa, desde que se somem os que consideram ser a vida no assentamento melhor ou igual à vida no assentamento.

Nas conversas derivadas na entrevista, muito recorrentemente se ouviu que ser dono da terra era melhor que trabalhar para outros. Isto ocorre, possivelmente, em função do fato de que "nos países pobres, os pobres são obrigados a vender o seu trabalho por um salário abaixo do seu valor, abaixo dos valores de suas necessidades de sobrevivência" (MARTINS, 2000).

É claro que este não é o único motivo, porém, faz parte de um ideário por traz dos movimentos políticos nos quais se inserem as formações de opinião pró reforma agrária.

Indo além, há a questão da valorização do proprietário rural das sociedades como a nossa, atribuindo-lhe um lugar social importante uma vez que ele conta com algum grau de produção direta dos meios de vida atenuando-se a coisificação da pessoa (MARTINS, 2000). 


\subsection{Análise descritiva da escolaridade}

A escolaridade é um dos parâmetros que podem interferir com a percepção de problemas ambientais, alvo principal deste estudo. É clara a correlação positiva entre o nível educacional e a conservação ambiental (MCDOWELL; SPARKS, 1989). Dentro desta linha, foram pesquisadas a escolaridade do entrevistado e a maior escolaridade dentre as pessoas que residem no lote.

\subsubsection{Caracterização da escolaridade do entrevistado}

Os primeiros resultados se referem à escolaridade dos entrevistados, Figura 14.

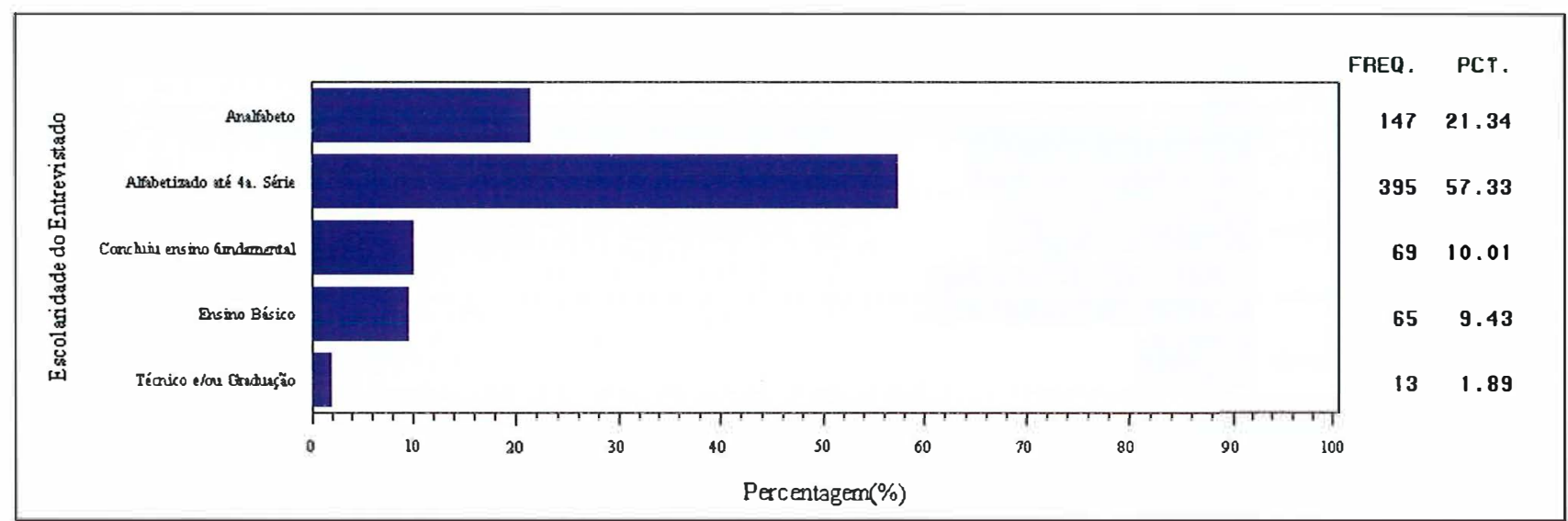

Figura 14 - Escolaridade do Entrevistado $\left(\chi^{2}: 666,51 ;\right.$ G.L.: 4; valor-p:<0,0001)

Observa-se uma significativa $(\mathrm{p}<0,0001)$ proporção de entrevistados que são alfabetizados ou que concluíram até a $4^{\mathrm{a}}$ série (Grupo Escolar). Em seguida aparece uma proporção bem grande de analfabetos sendo as demais categorias de estudo, menos freqüentes. De qualquer forma, o nível de escolaridade é muito baixo já que $78,67 \% \pm 3,59 \%$ dos entrevistados não concluiu o ensino fundamental, tendo sido alfabetizados ou terem concluído apenas a $4^{\mathrm{a}}$ série, antigo ensino primário.

Baixas escolaridades estão, muito comumente associadas às populações pobres, isto se confirma neste caso. Grande parte dos assentamentos do Estado de São Paulo se localiza na região do Pontal do Paranapanema, considerada por muitos como a segunda região mais pobre do Estado de São Paulo (LIMA et al, 2003). 
"Analisando os dados disponibilizados pelas diferentes fontes até o presente observase que a renda monetária média anual para as famílias brasileiras assentadas, 1996, foi de $\mathrm{R} \$ 3284,52$, correspondente a 30,41 salários mínimos, ou 2,54 salários mínimos mensais em média (CARMO, 2003).

\subsubsection{Caracterização do lote quando à maior escolaridade}

Ocorre, entretanto, que a perspectiva para este panorama de baixa escolaridade é muito positiva já que a maior escolaridade do lote tem uma distribuição totalmente diferente, conforme revela a Figura 15.

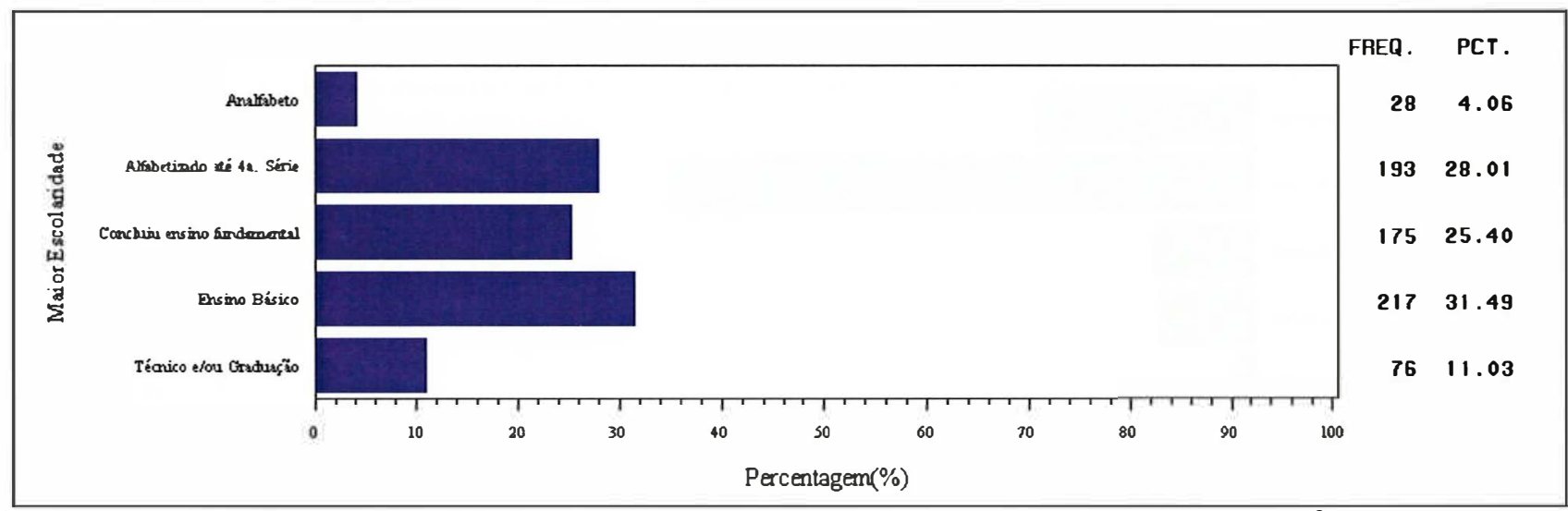

Figura 15 - Maior escolaridade encontrada dentre todos os moradores do lote $\left(\chi^{2}: 192,87\right.$; G.L.: 4; valor-p:<0,0001)

Há fortes indícios $(\mathrm{p}<0,0001)$ de que há diferença nas proporções de pessoas com a escolaridade máxima dentro do lote. Observa-se que há uma completa inversão onde se conclui que em apenas $4,06 \% \pm 3,59 \%$ dos lotes todas as pessoas são analfabetas, um valor quase desprezível. A maioria dos lotes $(67,92 \% \pm 3,59 \%)$ tem pelo menos uma pessoa com o ensino fundamental concluído o que representa, pelo menos 11 anos de estudo, havendo ainda uma representativa proporção de $10,03 \% \pm 3,59 \%$ que tem curso técnico elou graduação concluída, o que pode vir a representar um grande impacto em relação à adoção de novas tecnologias.

\subsubsection{Caracterização da estrutura familiar quando à máxima escolaridade}

Ainda relacionada à escolaridade perguntou-se sobre qual é a posição na família da pessoa que "foi mais longe nos estudos", Figura 16. 


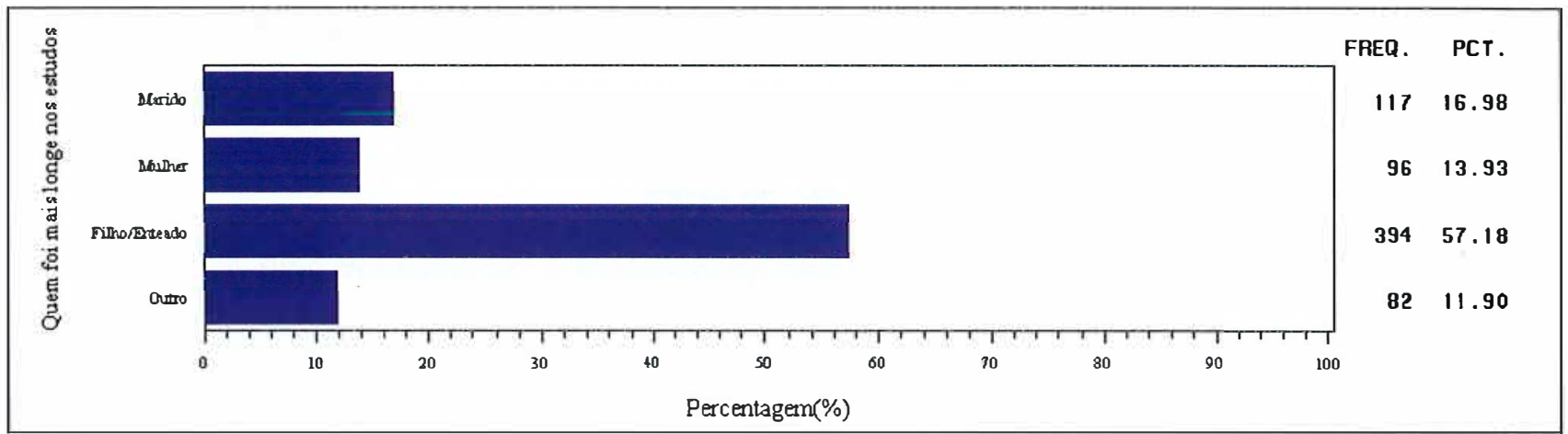

Figura 16 - Posição na família da pessoa com maior grau de escolaridade $\left(\chi^{2}: 384,24 ;\right.$ G.L.: 3; valor-p:<0,0001)

Observa-se que a situação significativamente $(\mathrm{p}<0,0001)$ mais freqüente é a de filhos ou enteados que têm a maior escolaridade o que explica a maior proporção de pessoas com ensino básico completo, já que este é o padrão mínimo atual de estudo.

Um indicador extremamente importante e, também de cunho social, é o de que a escolaridade da geração futura será, certamente maior que a atual já que em $57,18 \% \pm 3,59 \%$ dos casos a maior escolaridade do lote é a de um filho ou enteado.

\subsection{Análise descritiva dos parâmetros ambientais}

A construção de índices para medir características ambientais apresenta dificuldades em função da natureza subjetiva das avaliações dos obtidas através de um questionário (CLEMENTS, 1992 citado por BEEDEL; REHMAN, 1999).

Entretanto, os índices podem ser usados para se mensurar o valor ambiental dos recursos e a extensão de seu significado na tomada de decisão por parte dos produtores rurais (BEEDEL; REHMAN, 1999).

A avaliação dos índices de percepção ambiental deve ser feita com cautela uma vez que muitos assentamentos foram implantados em áreas que previamente desmatadas e degradadas anteriormente à criação do projeto de reforma agrária (ANICE, 2003), portanto, a atribuição da situação ambiental na qual se encontram os assentamentos é um erro. Deve-se considerar, também, que não existem evidências de que o risco ambiental dos assentamentos seja maior do que outras categorias de produtores rurais (TREVISAN, 1999). O risco ambiental é intrínseco ao uso da terra, independentemente do processo que permita o acesso a ela. Comparações de áreas de assentamento e do respectivo entorno através de imagens de satélite não revelaram maiores 
88

deteriorações das áreas florestadas no assentamento Pirituba 2 em relação ao entorno (KLUG et al, 2005).

\subsubsection{Caracterização da diversidade do uso da terra}

Índices de percepção ambiental são apresentados e iniciando-se pelo índice geral de diversidade do uso da terra (IGD), Figura 17.

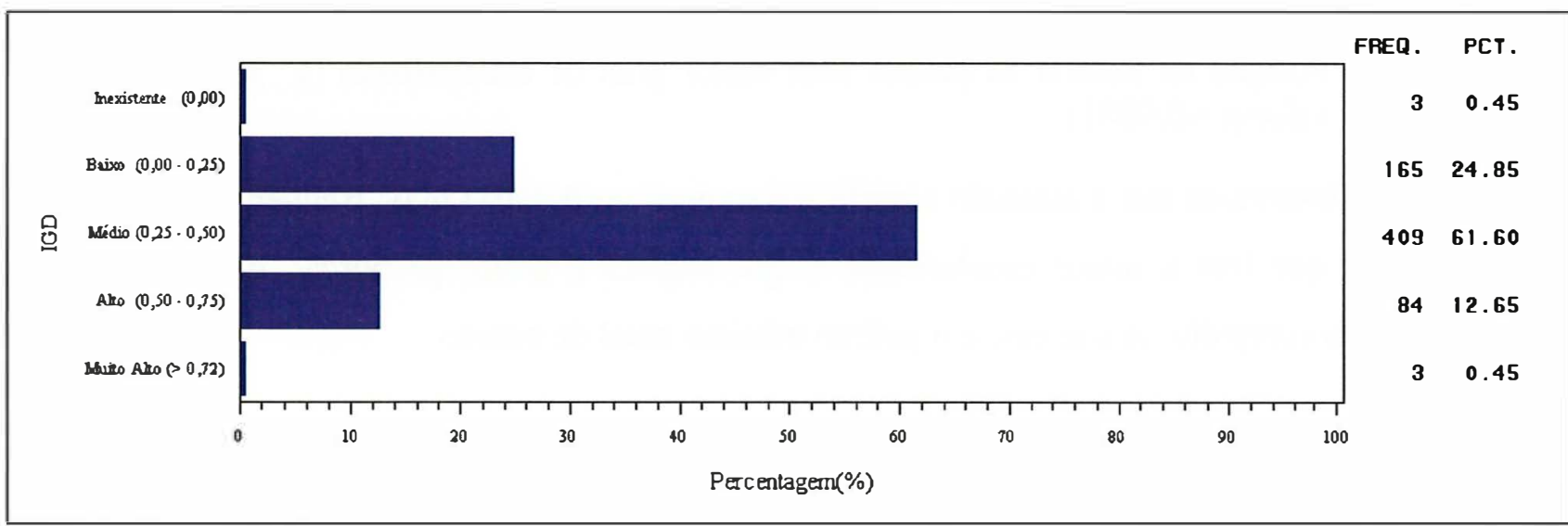

Figura 17 - Índice geral de diversidade do uso da terra $\left(\chi^{2}: 853,92 ;\right.$ G.L.: 4; valor-p:<0,0001)

Há fortes indícios $(\mathrm{p}<0,0001)$ de diferenças entre as proporções das diferentes classes do $I G D$, mas não há grande variabilidade em torno da média do número de usos dados às terras nos assentamentos do Estado de São Paulo. São muito raros os lotes sem uso, e muito raros os lotes onde se aplicam quase todos os tipos de uso pesquisados, o que, de fato não seria compatível com os tamanhos de lotes da reforma agrária paulista.

Ocorre, porém que pequenas propriedades rurais têm vantagens na supervisão do trabalho porque ela se utiliza mais do trabalho familiar. Esta linha de argumento sugere que qualquer tipo de reforma agrária que reduza a desigualdade da posse da terra terá um efeito positivo na produtividade, entretanto, a conclusão é a de que a bem conhecida relação inversa entre o tamanho da propriedade rural e a produtividade podem ser resultantes de mercados de crédito imperfeitos e da heterogeneidade das habilidades dos proprietários rurais (ASSUNÇÃO; MAITREESH, 2003).

Os diversos usos da terra são coerentes com a proposta de agricultura familiar impresso no modelo de reforma agrária onde há que se compatibilizar, no mesmo lote, as necessidades de consumo das famílias e a produção baseada na mão-de-obra familiar. 


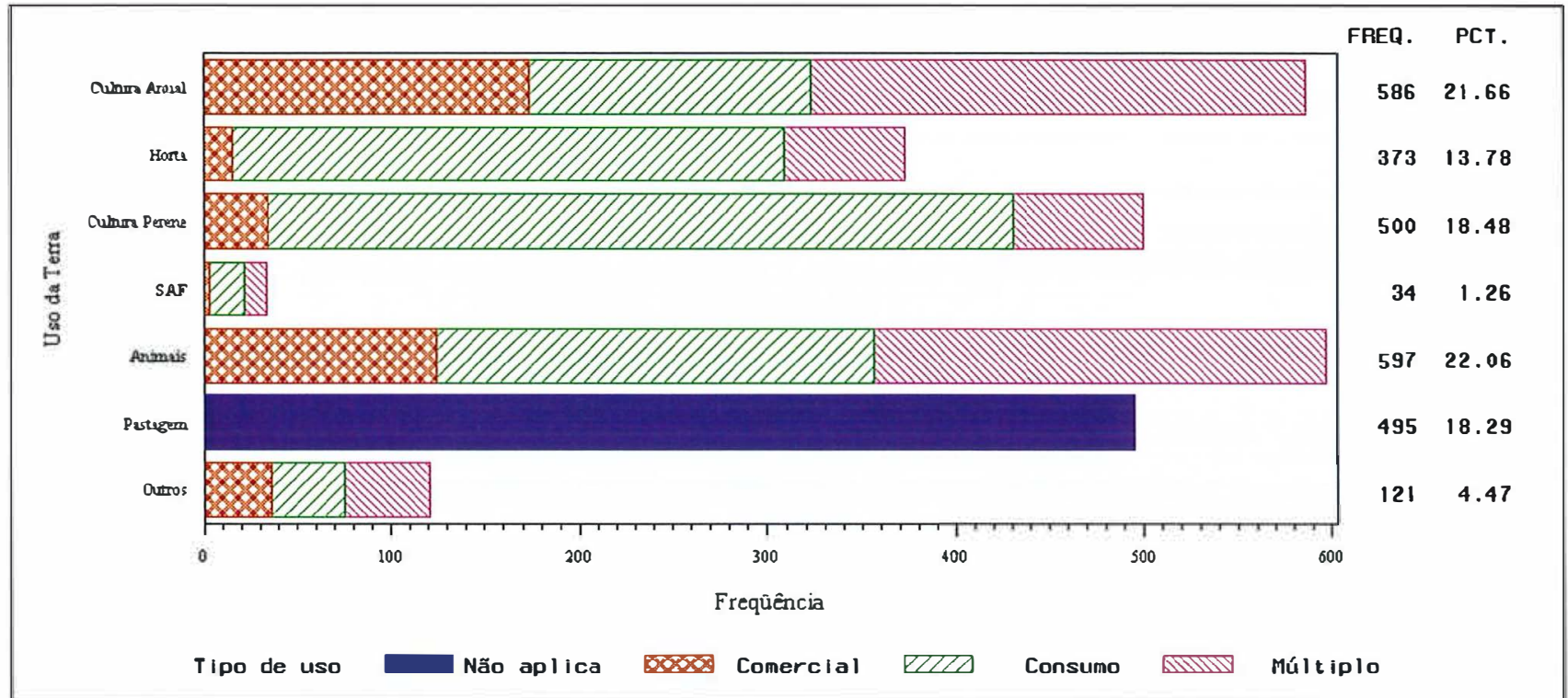

Figura 18 - Freqüência dos usos da terra nos assentamentos e nos respectivos tipos

São observadas as proporções de ocorrência dos usos previstos nesta pesquisa, da terra. Observa-se uma ocorrência muito baixa de Sistemas Agroflorestais (SAF), apesar das vantagens agroecológicas deste tipo de explotação da terra o que confirma que se tem dado muito pouca atenção para o potencial deste sistema na proteção de fragmentos florestais na forma de uma zona tampão (CULLEN JÚNIOR, 2001).

Sistema agroflorestal é um tipo de gerenciamento da terra no qual essencias arbóreas crescem nas mesmas unidades de manejo com plantas agricultáveis ou animais, em um arranjo especial ou em uma seqüiência temporal e com interações econômicas e ecológicas dos diferentes componentes (FERNANDES e NAIR 1986, MICHON e FORESTA 1999 citados por CULLEN JÚNIOR, 2001).

As culturas anuais e perenes ocorrem com grande freqüência e corroboram que boa parte da quantidade produzida em todo o País é para o consumo familiar (CARMO, 2003).

A criação de animais se destaca como a atividade que mais freqüentemente se desenvolve e somam-se neste item, tanto a pecuária como a criação de aves, bicho-da-seda e porcos, além de animais para trabalho como cavalos, mulas e burros. Associada à pecuária, principalmente leiteira, como pudemos perceber no decorrer das entrevistas, há o uso da terra com pastagens, muitas vezes oriunda da vocação natural do solo de grandes áreas de reforma agrária, sobretudo no Pontal do Paranapanema com solo originário de rochas do grupo Bauru, 
90

sendo latossolo, o tipo predominante na região. Além da elevada concentração de areias, destacam-se como principal característica: a baixa fertilidade natural (LIMA et al, 2003).

Chama atenção, a alta freqüência de ocorrência de hortas, tanto para consumo familiar, como para comercialização.

Há quase 60 anos, com a promissora emergência de idéias, movimentos e estatutos que se seguiram a Segunda Guerra Mundial, a luta contra a fome e a concepção de um estado de segurança alimentar e bem-estar nutricional passaram a figurar como grandes desafios no ideário das sociedades civis e na agenda dos poderes públicos. Assinala-se hoje um movimento no sentido de praticar a segurança alimentar como um referencial obrigatório dos direitos de cidadania. É o que está estabelecido no Pacto Internacional dos Direitos Econômicos, Sociais e Culturais. Mais do que os compromissos formais de signatário desse pacto, o Brasil representa antecedentes históricos valiosos que, agora, na grande mobilização do chamado "Projeto Fome Zero", devem ser resgatados (BATISTA FILHO, 2004).

Além das informações visando estabelecer a sustentabilidade dos assentados, existem as temáticas ambientais, que vêm tomando conta dos debates, sobretudo em decorrência do licenciamento ambiental dos projetos de reforma agrária (Resolução CONAMA 289/01).

De uma forma geral, cientistas sociais têm defendido que as pessoas que vivem em áreas rurais tendem a ver os recursos naturais em termos utilitários (favorável ao ambiente natural) em decorrência de sua dependência da atividade extrativista (WILSON, 1992).

\subsubsection{Caracterização da interação com a mata}

O índice de interação com a mata (IIM) tem sua distribuição estudada, Figura 19. 


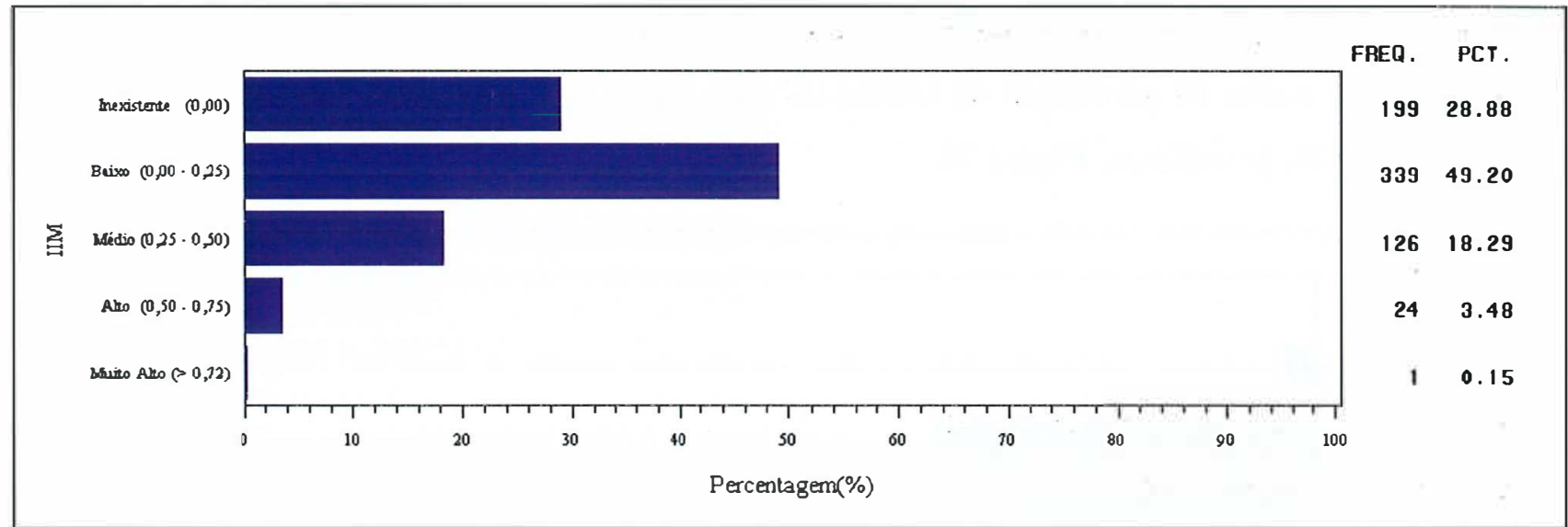

Figura 19 - Índice de Interação com a Mata $\left(\chi^{2}: 551,75 ;\right.$ G.L.: 4; valor-p:<0,0001)

Já se observa no caso deste índice uma assimetria à esquerda, decorrente de um maior número de entrevistados que revelaram não ter nenhum $(28,88 \%)$ ou uma baixa interação com a mata $(49,20 \%)$.

A grande maioria das pessoas assentadas no sudeste do Brasil, inclusive os migrantes "sem terra" vivendo no Pontal do Paranapanema, não estão familiarizados com as Florestas Tropicais de Terra Baixa. A maioria não tem tradição como caçadores de subsistência e coletores, tendo apenas experiência com a agricultura comercial. Cerca de $20 \%$ passou a maior parte de suas vidas nos centros urbanos (PÁDUA; PÁDUA; CULLEN JÚNIOR, 2002). Tal realidade pode ser observada, também na maior parte dos assentamentos do Estado de São Paulo já que interações com a mata exigem competências e habilidades que parecem não serem dominadas completamente, por grande parte dos assentados.

Por outro lado, a baixa interação com a mata também pode ser sintoma da ausência de matas com a qual interagir já que muitos assentamentos são implantados em áreas que foram desmatadas e degradadas anteriormente à criação do projeto de reforma agrária (ANICE, 2003).

A existência de vínculo entre os proprietários rurais e as áreas de mata é positiva à medida que existe uma forte relação entre a atitude conservacionista e a conservação ambiental (MACDOWELL, 1989) e existem muitos benefícios de trabalhar com uma participação educacional como a base de um programa sócio-ambiental. O envolvimento da comunidade tem sido diretamente ligado à proteção da floresta (PÁDUA; PÁDUA; CULLEN JÚNIOR, 2002). 
92

\subsubsection{Caracterização da percepção da erosão do solo}

O índice de percepção de erosão do solo (IES), já é algo mais ligado à preocupação com os recursos produtivos, Figura 20.

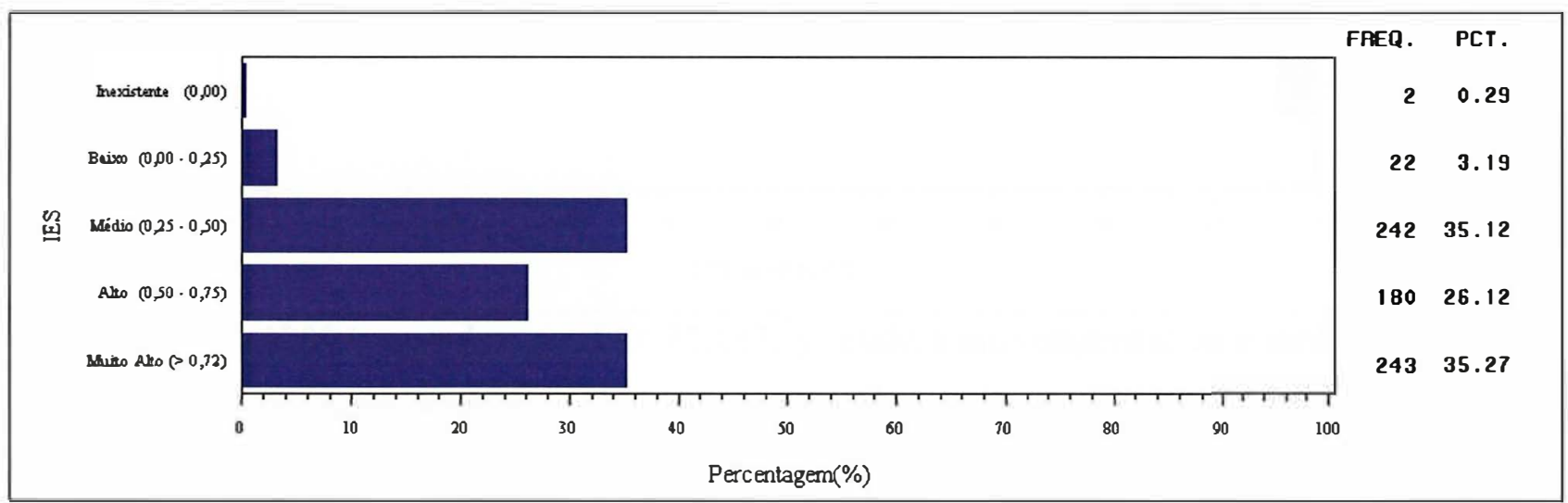

Figura 20 - Índice de percepção de erosão do solo $\left(\chi^{2}: 403,17\right.$; G.L.: 4; valor-p:<0,0001)

Há fortes indícios $(\mathrm{p}<0,0001)$ de diferenças entre as proporções do Índice de Percepção da Erosão. Altas percepções são bem mais freqüentes que os índices baixos, denotando uma maior afinidade à observação deste problema ambiental em relação a outros problemas estudados. Grande parte dos assentamentos visitados tinham sido beneficiados com a construção de terraços, mesmo assim, era bastante comum a observação de erosão, tanto laminar quanto em sulcos. De um lado, fruto da fragilidade do solo de grandes áreas ocupadas pelos assentamentos e, de outro, pela falta de recursos financeiros que limitam o proprietário na conservação das estruturas montadas pelo Estado.

\subsubsection{Caracterização da percepção de impacto sobre os recursos florestais}

Um outro tipo de percepção de impacto diz respeito aos recursos florestais o que envolve deste a remoção de madeira para lenha, na maior parte das vezes são coletados galhos secos até a remoção de árvores, tanto para uso doméstico como para uso comercial. A introdução da agricultura no estilo europeu levou a uma remoção em larga escala dos ecossistemas naturais e o seu uso para a produção de bens agrícolas (WILSON, 1992).

Já nos Estados Unidos da América, estimativas de perda de habitats naturais nos anos recentes variam entre 2.000.000 ha (DEKNATEL, 1979 citado por MACDOWELL, 1989) até 4.000.000 ha por ano (RONSBURGER, 1975, citado por MACDOWELL, 1989). 
Na Europa, a troca da vegetação natural por culturas foi completa, e quase não há traços da flora e fauna original (WILSON, 1992).

Nas áreas ocupadas mais recentemente pelos agricultores europeus como a Nova Zelândia e Estados Unidos da América ou África do Sul, remanescentes da vegetação natural ainda permanecem comuns na paisagem agrícola (WILSON, 1992).

O índice de percepção de impacto de recursos florestais $(I R F)$ analisado na Figura 21.

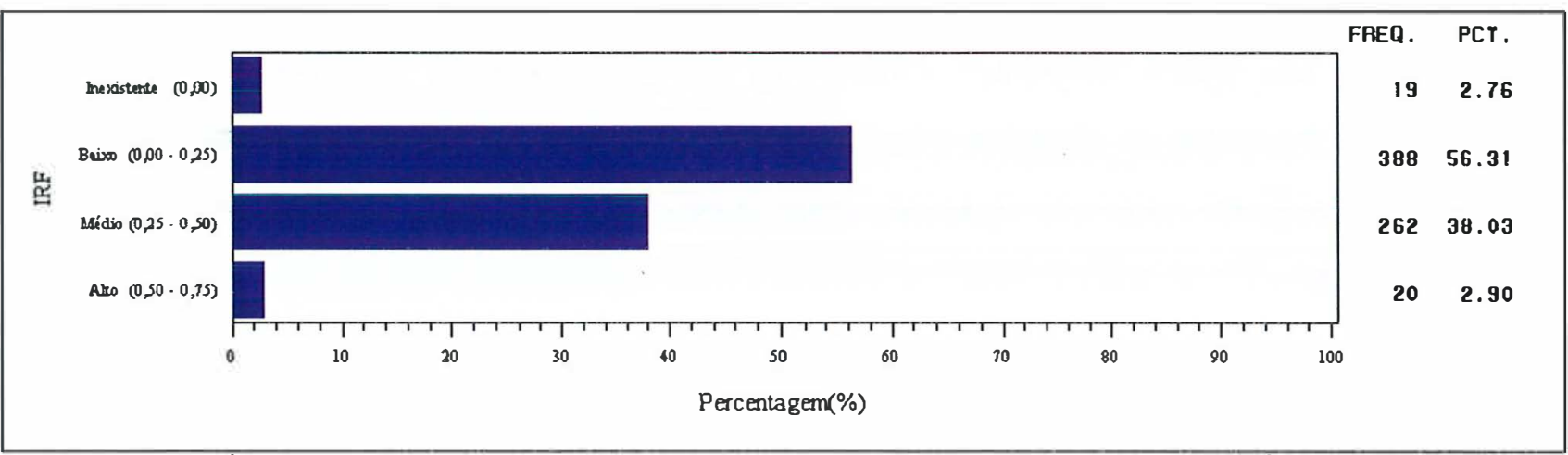

Figura 21 - Índice de percepção de impacto do uso de recursos florestais $\left(\chi^{2}: 587,92\right.$; G.L.: 3 ; valor-p: $<0,0001$ )

Há fortes indícios de diferenças significativas $(p<0,0001)$ entre as proporções de entrevistados nas classes de percepção de recursos florestais. Valores altos e baixos são preteridos em favor de valores intermediários, tendendo para uma baixa percepção.

Estudos mostram que os recursos vegetais são os mais explorados, sobretudo o uso de madeira para construção (BOER; BAQUETE, 1998).

A doação e redistribuição de terra no Pontal do Paranapanema, abastece as famílias sem terra com parcelas agricultáveis, o que o programa não fornece, todavia, são habilidades e assistência aos assentados, necessárias para que eles sejam produtivos e conservem os fragmentos restantes da floresta atlântica do interior (FENIMORE; CULLEN JÚNIOR, 002).

Já na região de do assentamento Pirituba II O estabelecimento do assentamento foi responsável pela supressão de florestas nativas em 5\% (345.61 ha), não se tratando, porém, de florestas primárias. Por outro lado, no entorno ocorreu uma diminuição de $33 \%$ de florestas nativas em 1984, 25 \% em 1993, 27 \% em 1996 e 2003. Pelas evidências das imagens entre os anos de 1984 e 1993 a diminuição de floresta é referente a algumas áreas nunca antes totalmente desmatadas, ou seja, de florestas primárias. As percentagens das áreas de floresta exótica 
94

permanecem praticamente estáveis durante o período estudado e atualmente representam $23 \%$ da área do entorno (KLUG; SHIMBO; ALVES; SPAROVEK, 2005), o que é uma evidência de que não é o assentamento de reforma agrária que gera impactos sobre os recursos florestais, mas a agricultura como um todo, independentemente do mecanismo de acesso à terra.

O Índice IRF revela a percepção da existência de consumo de recursos florestais em nível baixo e médio.

Os impactos sobre os recursos hídricos podem ser considerados como medianos já que os extremos são pouco freqüentes. Observa-se que muito poucos assentados desconhecem totalmente a existência de impactos sobre os recursos hídricos, ao mesmo tempo em que muito poucos o consideram como alto. A grande maioria percebe algum grau intermediário de impacto desta natureza.

Um outro tipo de impacto diz respeito aos recursos hídricos, Figura 22.

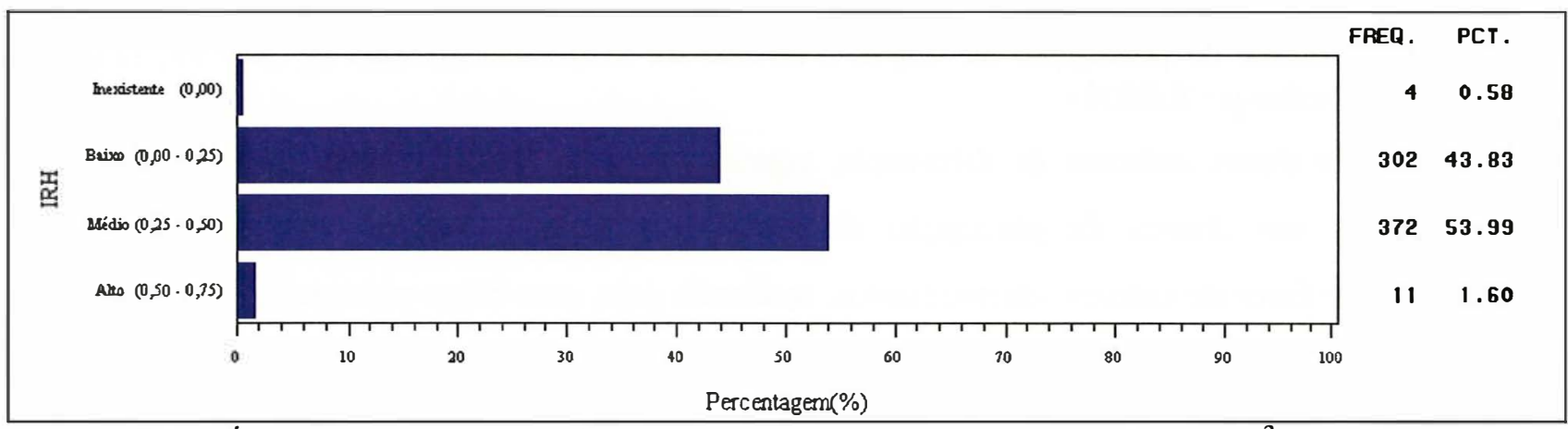

Figura 22 - Índice de percepção de impacto do uso de recursos hídricos $\left(\chi^{2}: 644,67\right.$; G.L.: 3; valor-p:<0,0001)

Há fortes indícios $(\mathrm{p}<0,0001)$ da existência de diferentes proporções dentro das categorias estabelecidas para o Índice de Percepção do Impacto de Recursos Hídricos (IRH), de forma que os extremo são bastante raros em comparação a uma percepção entre média e baixa que totaliza $97,82 \%$ da percepção.

\subsubsection{Caracterização da percepção da caça}

Pesquisas anteriores indicam uma atitude, dos agricultores, mais favorável ao ambiente natural que outros grupos, valorizando mais a fauna e the atribuindo um maior valor (WILSON, 1992).

Por fim, é avaliado o índice de percepção do impacto de caça (ICA), na Figura 23. 


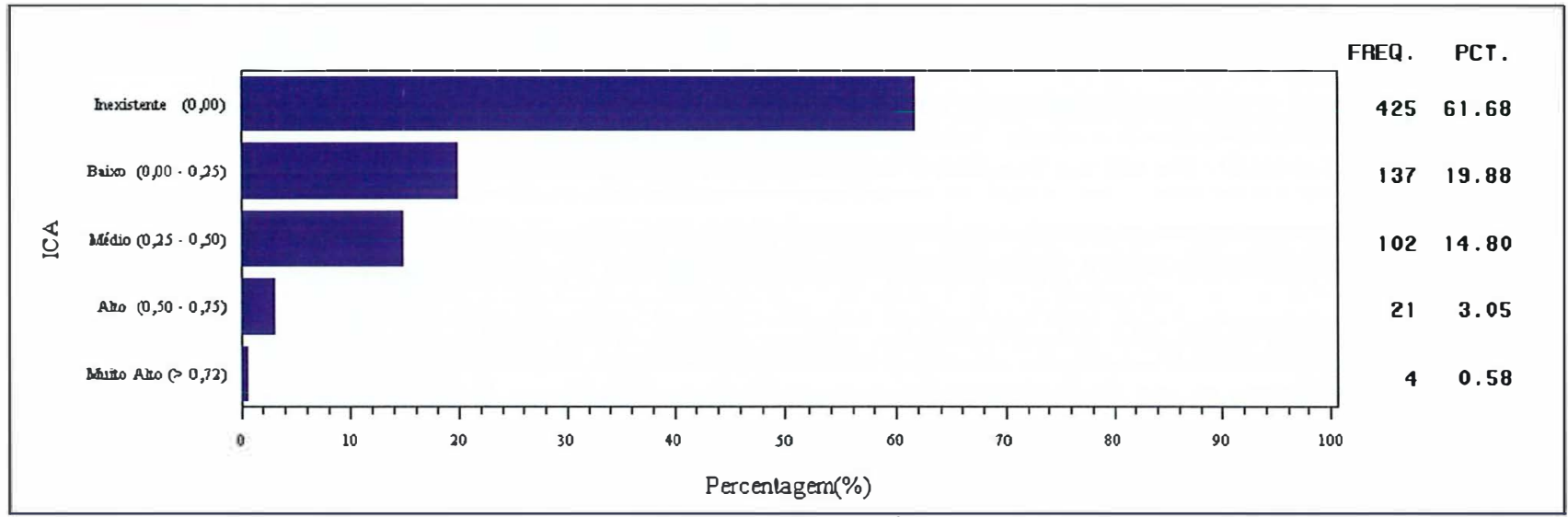

Figura 23 - Índice de percepção de impacto da caça $\left(\chi^{2}: 836,80 ;\right.$ G.L.: 4; valor-p:<0,0001)

A percepção de impacto de caça são muito pouco evidentes já que há fortes indícios $(p<0,0001)$ da existência de diferenças entre as categorias de percepções. Enquanto que $61,68 \% \pm$ $3,59 \%$ dos assentados apontam para impacto inexistente $(0,00), 19,88 \% \pm 3,59 \%$ perceber a existência de um impacto baixo e $14,80 \% \pm 3,59 \%$ revelam um impacto médio, sendo, praticamente, desprezíveis os relatos de impactos altos.

A maioria dos estudos conduzidos a respeito do impacto da caça tem sido conduzida em áreas de floresta contínua, principalmente na Amazônia. Nestas áreas, colonizadores têm causado declínio da abundância das espécies (EMMONS, 1984; BODMER et al., 1988; GLANZ, 1991 citado por CULLEN JÚNIOR; BODMER; PÁDUA, 2000).

Estudos conduzidos no Estado de São Paulo revelaram que a maior parte das espécies usadas para subsistência tiveram um decréscimo das abundâncias em locais com caça leve ou pesada. Por outro lado, não existem tendências de abundância e pressão de caça das espécies não relacionadas com subsistência tais como esquilos e macacos (CULLEN JÚNIOR; BODMER; PÁDUA, 2000).

\subsection{Aderência dos parâmetros ambientais aos estratos}

A premissa que fundamenta a amostragem estratificada é a representatividade de todos os grupos distintos que compõem a população, por isto, por menos freqüente que um grupo seja, pelo menos um elemento dele deve ser parte da amostra. 
Uma vez garantidas as condições de "não-exclusão", preocupa-se em um segundo momento com a proporcionalidade da ocorrência, daí a necessidade de que grupos mais numerosos na população sejam, também, mais numerosos na amostra.

Respeitando estes dois princípios fundamentais da amostragem e através de dados preliminares coletados por SPAROVEK, 2002, foram construídos 16 estratos populacionais representados no processo de amostragem estratificada adotada no delineamento amostral.

Propõe-se o teste da existência de aderência aos pressupostos de estratificação e os índices de percepção ambiental propostos. Para tanto, utilizou-se uma análise discriminante que usou como classificatória a informação do estrato populacional ao qual pertence o questionário e como variáveis quantitativas, os índices propostos.

Inicia-se a apresentação dos resultados com o estudo de seleção de variáveis discriminantes através do método stepwise, Tabela 11.

Tabela 11 - Resultado do processo de seleção de variáveis discriminantes para variável classificatória estrato amostral

\begin{tabular}{|c|c|c|c|c|c|}
\hline \multirow[b]{2}{*}{ Passo } & \multirow[b]{2}{*}{ Variável } & \multirow[b]{2}{*}{$\mathrm{R}^{2}$ Parcial } & \multicolumn{3}{|c|}{ Valores - p } \\
\hline & & & $\mathrm{F}$ & $\begin{array}{l}\text { Wilk's } \\
\text { Lambda }\end{array}$ & $\begin{array}{c}\text { Correlação } \\
\text { canônica } \\
\text { quadrada } \\
\text { média }\end{array}$ \\
\hline 1 & IRF & 0,1762 & $<, 0001$ & $<, 0001$ & $<, 0001$ \\
\hline 2 & IRH & 0,1502 & $<, 0001$ & $<, 0001$ & $<, 0001$ \\
\hline 3 & IIM & 0,0858 & $<, 0001$ & $<, 0001$ & $<, 0001$ \\
\hline 4 & IES & 0,0728 & $<, 0001$ & $<, 0001$ & $<, 0001$ \\
\hline 5 & IGD & 0,0480 & 0,0064 & $<, 0001$ & $<, 0001$ \\
\hline 6 & ICA & 0,0390 & 0,0395 & $<, 0001$ & $<, 0001$ \\
\hline
\end{tabular}

Observa-se que todas as variáveis propostas são significativas na determinação dos estratos amostrais propostos, quando utilizados todos os critérios estatísticos: teste F, Lambda de Wilk e Correlação Canônica Quadrada Média. A variável que mais contribui com a discriminação dos grupos é o Índice de Recursos Florestais (IRF) com coeficiente de determinação parcial ( $\mathrm{R}^{2}$ Parcial) de 17,62\%.

Tal comportamento é esperado uma vez que o IRF está relacionado a medidas correlatas de 5 das 8 variáveis utilizadas no delineamento amostral \% de RL preservada, \% de APP preservada, Famílias que extraem madeira, Área com Melhoria Ambiental e Área 
Desmatada após a criação do PA. Com este resultado, conclui-se que há uma associação entre os dados coletados nas duas pesquisas, naquela que criou os grupos de estratificação com base em um menor número de questionários por projeto de assentamento e uma pesquisa menos abrangente, porém, que aborda um maior número de entrevistados.

A segunda variável com maior contribuição discriminante é o Índice de Recursos Hídricos (IRH) com coeficiente de determinação de 15,02\%.

Os demais índices contribuem individualmente com menos que $10 \%$ de coeficientes de determinações parciais, mas ainda assim se mostram altamente significativos.

Uma vez determinada a importância de todos os índices na discriminação dos estratos, passou-se ao estudo de multinormalidade com objetivo de se fundamentar a escolha da técnica discriminante mais apropriada, Tabela 12.

Tabela 12 - Teste de normalidade univariada de Shapiro-Wilk e testes de Mardia e de HenzeZirkler para multinormalidade dos índices IRF, IRH, IIM, IES, IGD e ICA

\begin{tabular}{ccccc} 
Variável & & Teste estatístico & & Valor-p \\
\cline { 1 - 1 } IRF & & W de Shapiro-Wilk & & $<, 0001$ \\
IRH & & W de Shapiro-Wilk & & $<, 0001$ \\
IIM & & W de Shapiro-Wilk & & $<, 0001$ \\
IES & & W de Shapiro-Wilk & & $<, 0001$ \\
IGD & & W de Shapiro-Wilk & & $<, 0001$ \\
ICA & & W de Shapiro-Wilk & & $<, 0001$ \\
Sistema & & Assimetria de Mardia & & $<, 0001$ \\
& & Curtose de Mardia & & 0,1468 \\
& & T de Henze-Zirkler & & $<, 0001$
\end{tabular}

Apesar da inexistência de indícios de problemas pelo coeficiente de curtose de Mardia, há sólidos indícios de assimetria $(\mathrm{p}<0,01)$ e de falta de aderência à distribuição multinormal pelo teste de Henze-Zirkler. Em uma visão univariada, não há indícios de normalidade em nenhum dos índices.

Conclui-se pela inadequação da aplicação de técnicas que dependam da multinormalidade, inclusive técnicas discriminantes, por isto, serão aplicadas técnicas nãoparamétricas. 
A análise discriminante principia com as distâncias generalizadas pareadas entre os grupos. Esta matriz de distâncias é utilizada em uma análise de agrupamento e posteriormente, testes multivariados foram aplicados para comparar a composição dos grupos, Figura 24.

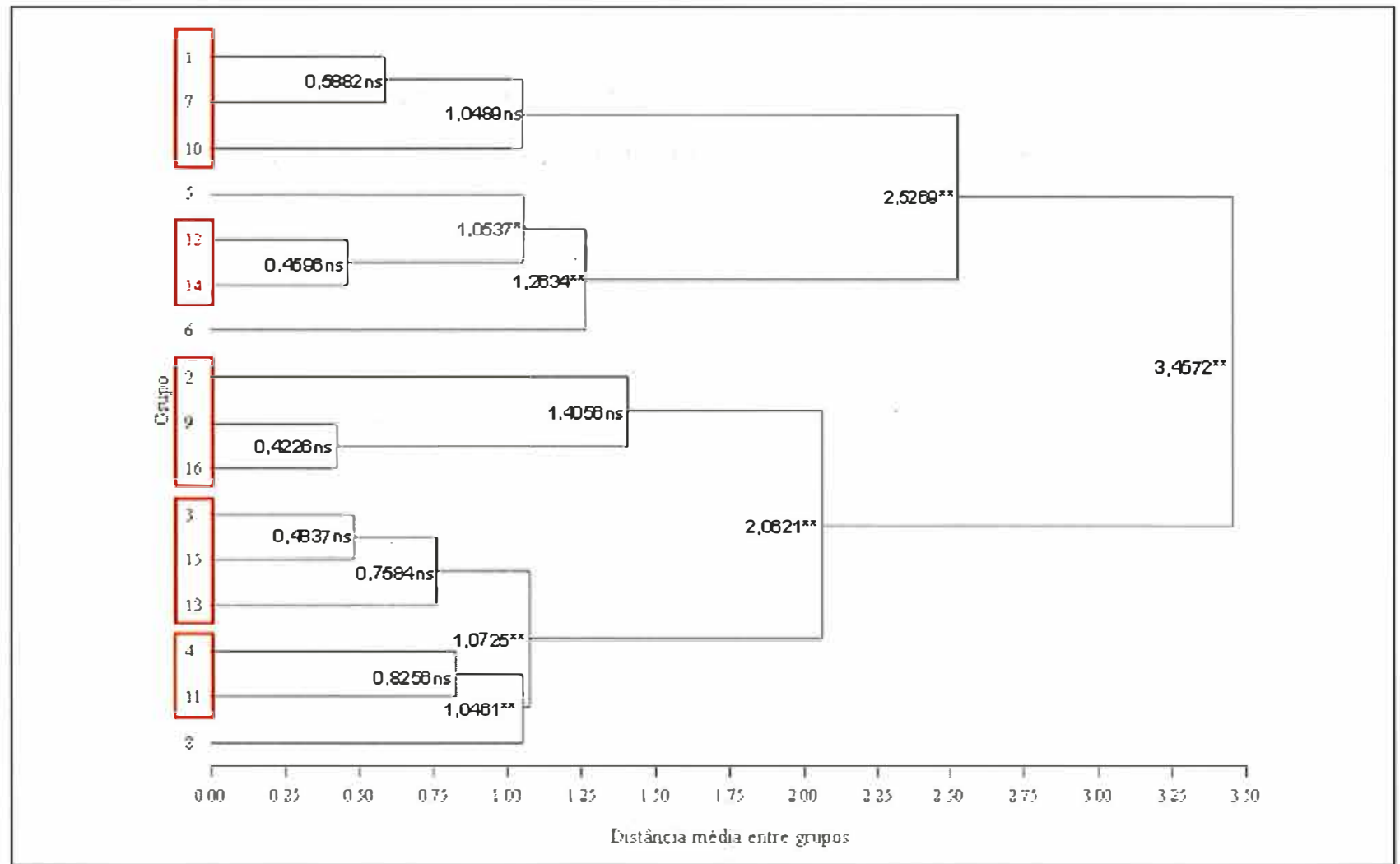

Figura 24 - Distâncias entre grupos e resultado mais significativos dentre os testes multivariados(Traço de Pilai, Lambda de Wilk, Traço de Hotelling-Lawley e Raiz máxima de Roy) para os estratos

O teste revela que, com base nos índices de percepção e interação com o meio ambiente se chegaria a apenas 8 estratos ao invés dos 16 originalmente propostos. $\mathrm{O}$ grupos $1,7 \mathrm{e}$ $10 ; 12$ e 14;2, 9 e 16;3, 15 e 13; 4 e 11 não apresentam distâncias significativas entre si, e por isto não seriam separados.

Diversos fatores podem ter contribuído para esta maior homogeneidade dos assentamentos neste levantamento em relação ao anterior:

a) O presente levantamento tem um maior número de questionários por assentamento 0 que tende a homogeneizar as respostas, fruto do aumento no número de opiniões. 
b) Opiniões menos divergentes uma vez que o estudo de SPAROVEK, 2002 contemplava poucos questionários e, muitas vezes, com opiniões estruturalmente divergentes (empreendedor social tais como INCRA e ITESP e movimentos sociais tais como MST, MAST, entre outros).

c) O levantamento anterior tinha como fundamento a coleta de dados em todos os assentamentos e o presente estudo obteve dados em apenas alguns assentamentos. Apesar da pretensa uniformidade, é óbvio que um levantamento amostral pode deixar passar divergências captadas em um levantamento mais abrangente.

De forma geral, observa-se uma boa associação entre os parâmetros ambientais e os estratos uma vez que todos eles conferem poder discriminante ao modelo.

Por fim, a análise discriminante permite avaliar através do processo de reclassificação, a validade do modelo para se determinar o grupo a partir dos índices, Figura 25. 


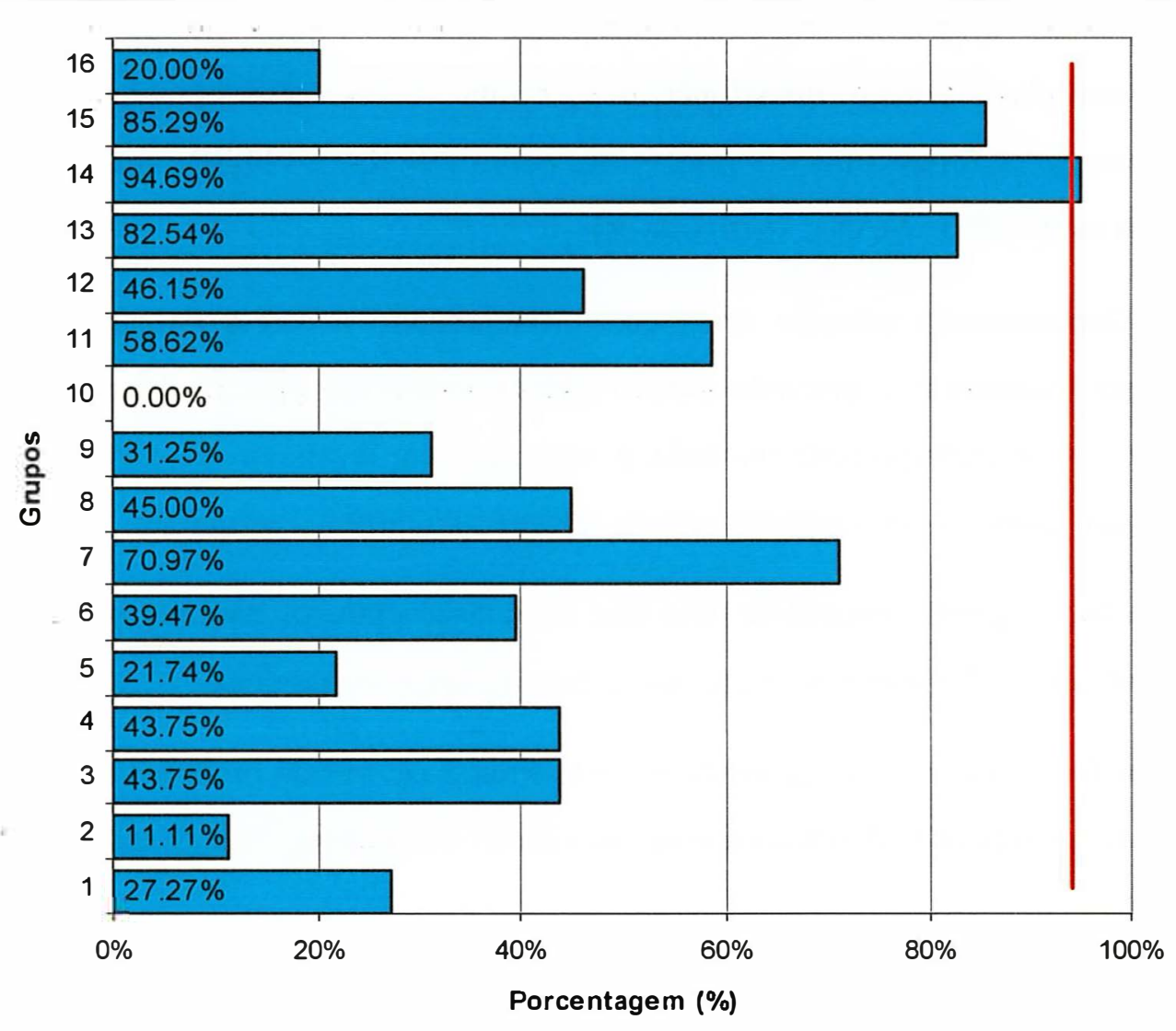

Figura 25 - Taxas de erro calculadas com base no processo de reclassificação dos dados dos índices de percepção e interação ambiental. A Faixa vermelha representa a probabilidade de erro no caso da classificação aleatória $(93,75 \%)$

Observa-se que apenas no grupo 14 há uma margem de erro superior à que se obteria no caso da atribuição dos dados a um grupo com base no acaso. A linha vermelha representa a probabilidade de erro no caso da atribuição casual e as barras representam as taxas de erro observadas pelo processo de reclassificação. Convém observar que o Grupo 14 é o mais numeroso o que resulta em uma maior variabilidade intragrupo e, possivelmente, na reunião de opiniões mais divergentes.

Os grupos com taxas de erro menores apresentam características mais marcantes, através das quais se chega mais claramente à sua identificação a partir das medidas observadas. Nos grupos com taxas de erros maiores, há falhas de classificação de forma que dados conduzem à atribuição de um grupo incorreto. 


\subsection{Aderência dos parâmetros ambientais às classes educacionais}

Um dos objetivos do presente estudo é a avaliação do efeito da educação sobre a percepção ambiental e, de forma similar aos grupos criados com objetivo de estratificação, há o interesse de se detectar a possibilidade de discriminação a partir dos dados de percepção e interação ambiental.

Inicia-se a apresentação dos resultados com o estudo de seleção de variáveis discriminantes através do método stepwise, Tabela 13.

Tabela 13 - Resultado do processo de seleção de variáveis discriminantes para variável classificatória grupo educacional

\begin{tabular}{|c|c|c|c|c|c|}
\hline \multirow[b]{2}{*}{ Passo } & \multirow[b]{2}{*}{ Variável } & \multirow[b]{2}{*}{$\mathrm{R}^{2}$ Parcial } & \multicolumn{3}{|c|}{ Valores - $\mathrm{p}$} \\
\hline & & & $\mathrm{F}$ & $\begin{array}{l}\text { Wilk's } \\
\text { Lambda }\end{array}$ & $\begin{array}{l}\text { Averaged } \\
\text { Square } \\
\text { Canonical } \\
\text { Correlation }\end{array}$ \\
\hline 1 & IES & 0,0270 & 0,0062 & 0,0062 & 0,0062 \\
\hline 2 & IRH & 0,0170 & 0,0793 & 0,0035 & 0,0035 \\
\hline 3 & IRF & 0,0146 & 0,1388 & 0,0028 & 0,0029 \\
\hline
\end{tabular}

Observa-se que apenas 3 das 6 variáveis testadas foram classificadas como significativas na discriminação dos dados de escolaridade: IES, IRH e IRF.

Observa-se que os valores dos coeficientes de determinação parciais são bem menores que os obtidos na análise discriminante de estratos. Enfim, a relação entre impactos ambientais e escolaridade é significativo.

A variável com maior poder de discriminação da escolaridade é o Índice de Erosão do Solo, seguido pelo Índice de Recursos Hídricos e, por fim, o Índice de Recursos Florestais.

Tabela 14 - Teste de normalidade univariada de Shapiro-Wilk e testes de Mardia e de HenzeZirkler para multinormalidade dos índices IRF, IRH, IES

\begin{tabular}{lll}
\hline \multicolumn{1}{c}{ Variável } & Teste estatístico & Valor-p \\
\cline { 2 - 3 } IRF & W de Shapiro-Wilk & $<, 0001$ \\
IRH & W de Shapiro-Wilk & $<, 0001$ \\
IES & W de Shapiro-Wilk & $<, 0001$ \\
Sistema & Assimetria de Mardia & $<, 0001$ \\
& Curtose de Mardia & $<, 0001$ \\
& T de Henze-Zirkler & $<, 0001$ \\
\hline
\end{tabular}


102

Não há indícios que permitam concluir que a idéia de multinormalidade é razoável, e nenhuma das variáveis também se mostra normalmente distribuída.

Conclui-se pela inadequação da aplicação de técnicas que dependam da multinormalidade, inclusive técnicas discriminantes, por isto, serão aplicadas técnicas nãoparamétricas. A análise discriminante principia com as distâncias generalizadas pareadas entre os grupos de escolaridade. A matriz de distâncias é utilizada em uma análise de agrupamento e posteriormente, testes multivariados foram aplicados para comparar a composição dos grupos, Figura 26.

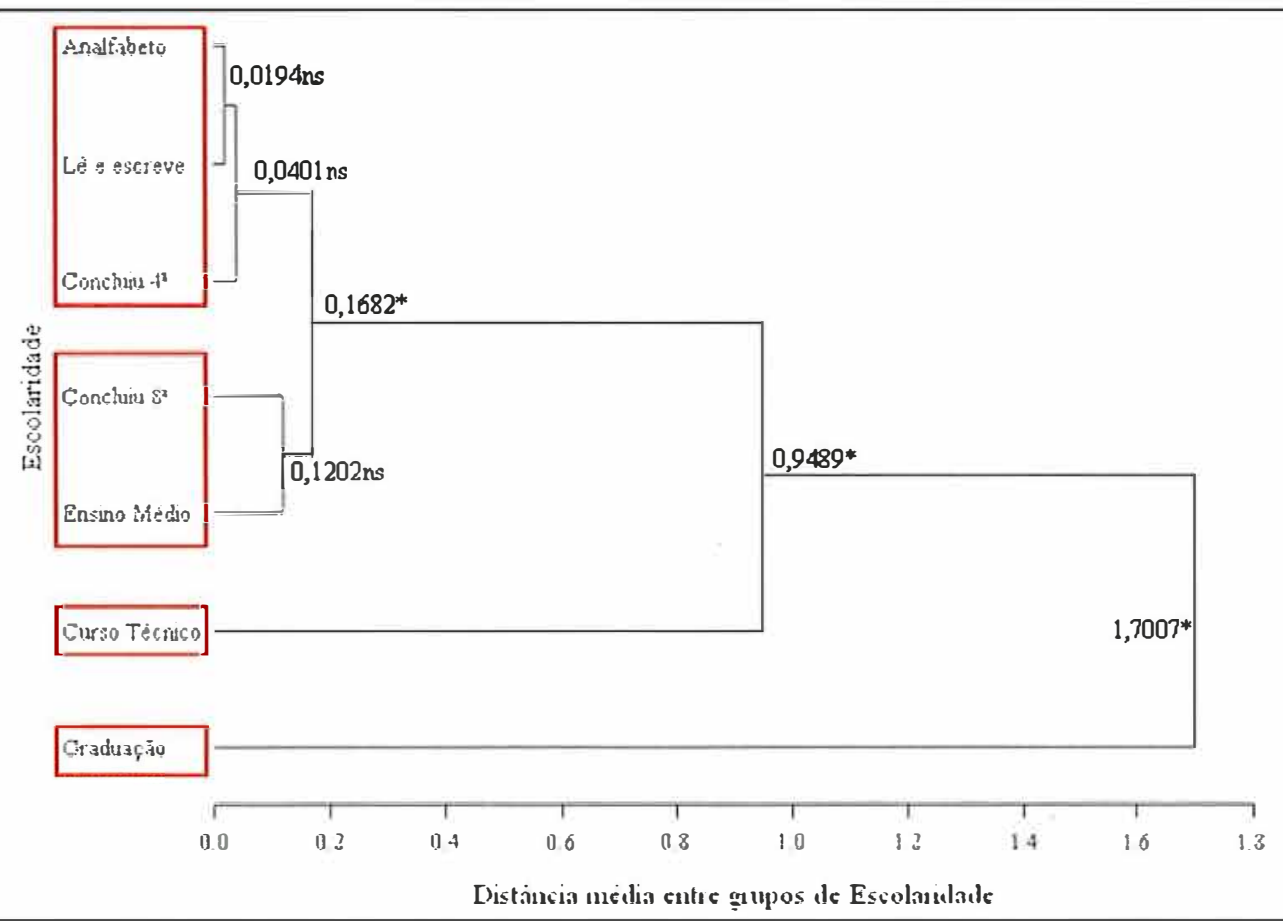

Figura 26 - Distâncias entre grupos de escolaridade e resultado mais significativos dentre os testes multivariados(Traço de Pilai, Lambda de Wilk, Traço de Hotelling-Lawley e Raiz máxima de Roy) para os estratos - ns indica distância não significativa no nível de $5 \%$, * indica distância significativa a $5 \%$ e ** a $1 \%$

São observados fortes indícios de que a escolaridade pode ser diferenciada através dos índices de percepção e interação ambientais.

Observa-se que no nível de significância de $5 \%$ não há indícios de que se possam discriminar os grupos: "Analfabetos", "Lê e Escreve" e "Concluíram a $4^{a}$ série".

Também não são encontrados indícios de que se possa discriminar os que concluíram a "8a série" e o "Ensino Médio". 
Há indícios de que estes dois grupos possam ser discriminados entre si, dos que concluíram o "Curso Técnico" e "Graduação". Também há indícios de que através dos índices se possam discriminar os que concluíram "Curso Técnico" dos que concluíram "Graduação".

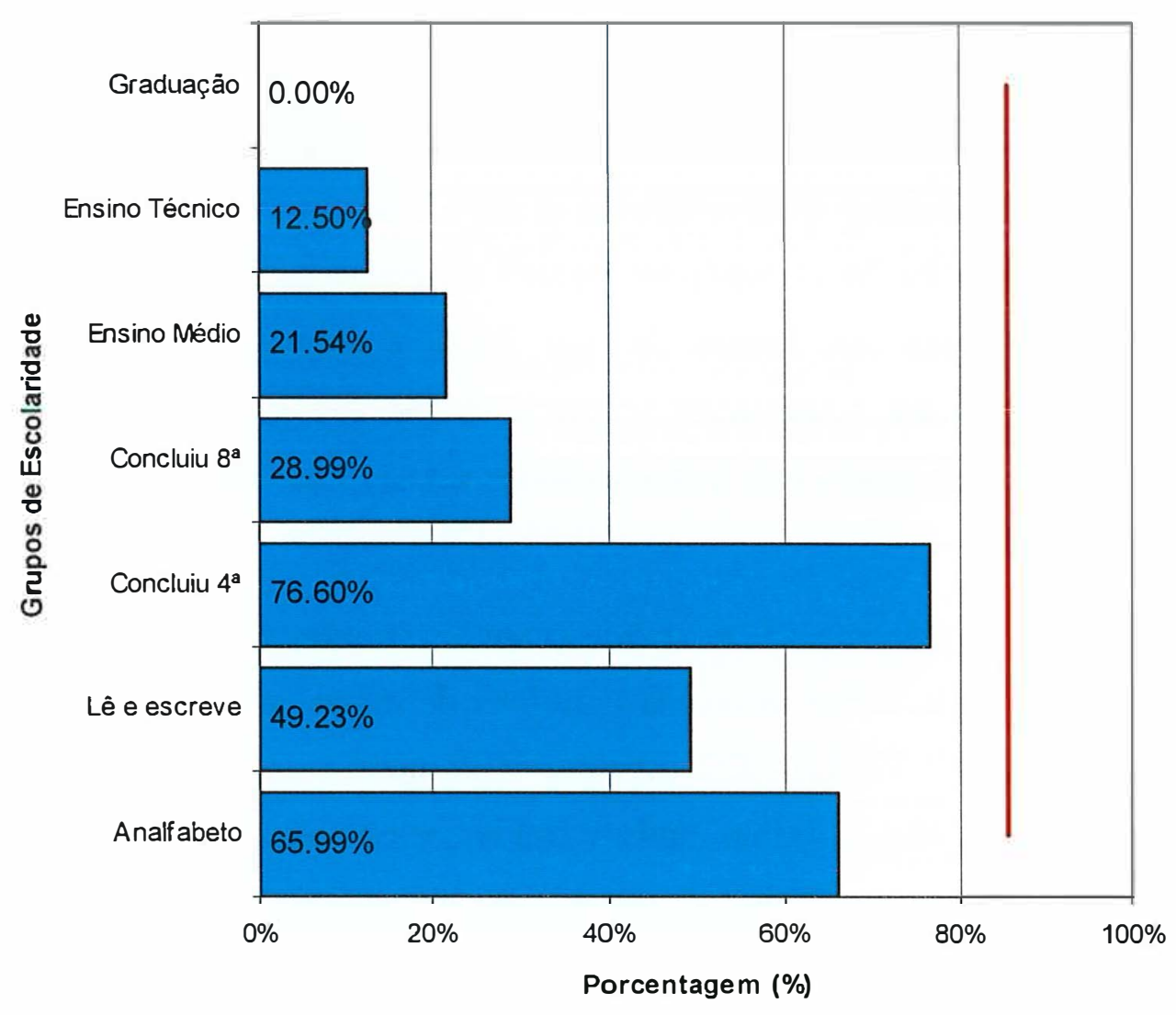

Figura 27 - Taxas de erro calculadas com base no processo de reclassificação dos dados dos índices de percepção e interação ambiental. A Faixa vermelha representa a probabilidade de erro no caso da classificação aleatória $(85,71 \%)$

A margem de confusão na discriminação das três classes com menor escolaridade é bastante grande, fruto da proximidade que se estabelece dentro destes três grupos que, conforme já observado, não diferem entre si.

Nas faixas de maior escolaridade as classificações erradas já se reduzem bastante, ficando muito aquém da classificação que se obteria ao acaso.

Observam-se indícios de que a percepção ambiental se modifica no grupo com escolaridade mínima de $8^{\mathrm{a}}$ série, não havendo peculiaridades que permitam a discriminação da pertinência da pessoa de grupos com escolaridades inferiores a esta. 
Observa-se que conforme se aumenta a escolaridade, mais característica e uniforme vai ficando a percepção ambiental de forma que perfeitamente se distinguem as opiniões das pessoas com curso superior uma vez que não existiu classificação errada.

Sendo assim, do ponto de vista da educação básica e tendo em vista a obtenção de benefícios no campo ambiental, deve-se traçar como meta a conclusão do ensino básico uma vez que somente são observadas mudanças sensíveis na percepção ambiental no grupo que, pelo menos, tenha concluído o ensino médio. Saliente-se que a proporção de assentados entrevistados que não concluíram o ensino básico perfazem $88,68 \%$ da população de assentados tomadores de decisão dos assentamentos do Estado de São Paulo e nesta proporção se encontram, principalmente, pessoas com idades mais avançadas o que nos dá indícios de que a efetiva convivência no ambiente escolar e o conteúdo lecionado são mais efetivos que a experiência adquirida com a idade.

Esta é a porcentagem a ser atingida no caso de um programa que objetive melhorar a percepção ambiental e, de forma associada contribua de outras maneiras para o sucesso do processo de assentamento. Também se estabelece como meta, a necessidade de que se atinja níveis de educação superiores ao ensino fundamental já que este não impinge grandes diferenças de comportamento e percepção, inclusive, em relação aos analfabetos, sendo as diferenças de percepção, somente observadas após este degrau educacional.

Considerando-se que em $57,18 \%$ dos lotes, a maior escolaridade no lote pertence a filhos ou enteados e não ao entrevistado tomador de decisões, conclui-se que os esforços de políticas educacionais podem estar atingindo as próximas gerações de moradores, mas não estão sendo eficientes em atingir as pessoas que tomam decisões neste momento. Isto indica a necessidade de um maior direcionamento para a educação de adultos, ou então, terá sido feita uma opção pelas gerações futuras, as quais poderão ter conhecimentos maiores que os da geração atual, mas que, porém, poderão não ter os recursos necessários para implantar estas idéias.

\subsection{Capacitação}

Dentro das premissas que fundamentam o trabalho, a capacitação assume um segundo degrau dentro do elo de tomada de decisões para a implantação de políticas públicas dentro dos assentamentos. 
De implantação mais simples e menos onerosa, as políticas de capacitação podem se embasar em treinamento de curta duração e com temas específicos, diferentes das políticas educacionais, de espectro mais amplo em termos de conteúdos e tempo.

A observação dos diversos graus de capacitação durante as entrevistas se respaldaram em questões de cunho de produção rural as quais puderam avaliar o conhecimento dos produtores em relação a 4 tópicos: conhecimento à respeito do uso de agrotóxicos, conhecimento à respeito de erosão, conhecimento à respeito da implantação de florestas nativas ou não e a participação em treinamentos de capacitação.

Através das questões $6.2,6.4,6.7$ e 6.10 pode-se avaliar o conhecimento dos assentados em relação ao uso de agrotóxicos, os riscos e características; através das questões $10.1,10.4,10.5$ e 10.6 foi quantificado o conhecimento do processo de erosão do solo assim como sobre procedimentos para mitigação; através das questões 12.1, 12.2, 12.4 e 12.5 foi feita a avaliação da capacitação para implantação de florestas nativas ou de florestas com essências exóticas e, por fim, a participação em treinamentos foi avaliada através das questões 11.3 e 11.4.

Através destas questões foi aplicado um estudo de agrupamento (Cluster Analisys) com objetivo de se classificar os diversos graus de capacitação do ponto de vista multivariado, ou seja, considerando a todas as características conjuntamente.

O início deste estudo exige que se estabeleça um grau de heterogeneidade tolerada dentro dos grupos, o que é feito através do estabelecimento de uma distância mínima entre grupos. A seleção da distância mínima é arbitrária e depende do número de grupos desejados e pode ser apoiada através da estatística Pseudo- $\mathrm{t}^{2}$ que permite a escolha de pontos ótimos próximos ao número de grupos desejados, Tabela 15. 
106

Tabela 15 - Características do processo de agrupamento nos últimos 8 níveis com objetivo de selecionar o ponto de corte apropriado através da estatística Pseudo- $\mathrm{t}^{2}$

\begin{tabular}{|c|c|c|c|c|}
\hline $\begin{array}{l}\text { Número do } \\
\text { Grupo }\end{array}$ & \multicolumn{2}{|c|}{ Grupos unidos } & Pseudo- $\mathrm{t}^{2}$ & Distância \\
\hline 7 & CL14 & CL9 & 72,0 & 0,7365 \\
\hline 6 & CL12 & CL33 & 16,9 & 0,7578 \\
\hline 5 & CL8 & CL38 & 7,1 & 0,8517 \\
\hline 4 & CL7 & CL11 & 50,2 & 0,8657 \\
\hline 3 & CL10 & CL6 & 274,0 & 0,8836 \\
\hline 2 & CL5 & CL3 & 361,0 & 1,0229 \\
\hline 1 & CL2 & CL4 & 331,0 & 1,3134 \\
\hline
\end{tabular}

Através da estatística Pseudo- $t^{2}$ obtém-se sugestões de pontos ótimos para a definição dos grupos e um ponto conveniente é o que determina a formação de 5 grupos com distância padronizada de 0,8517 entre eles, conforme ilustra a Figura 28.

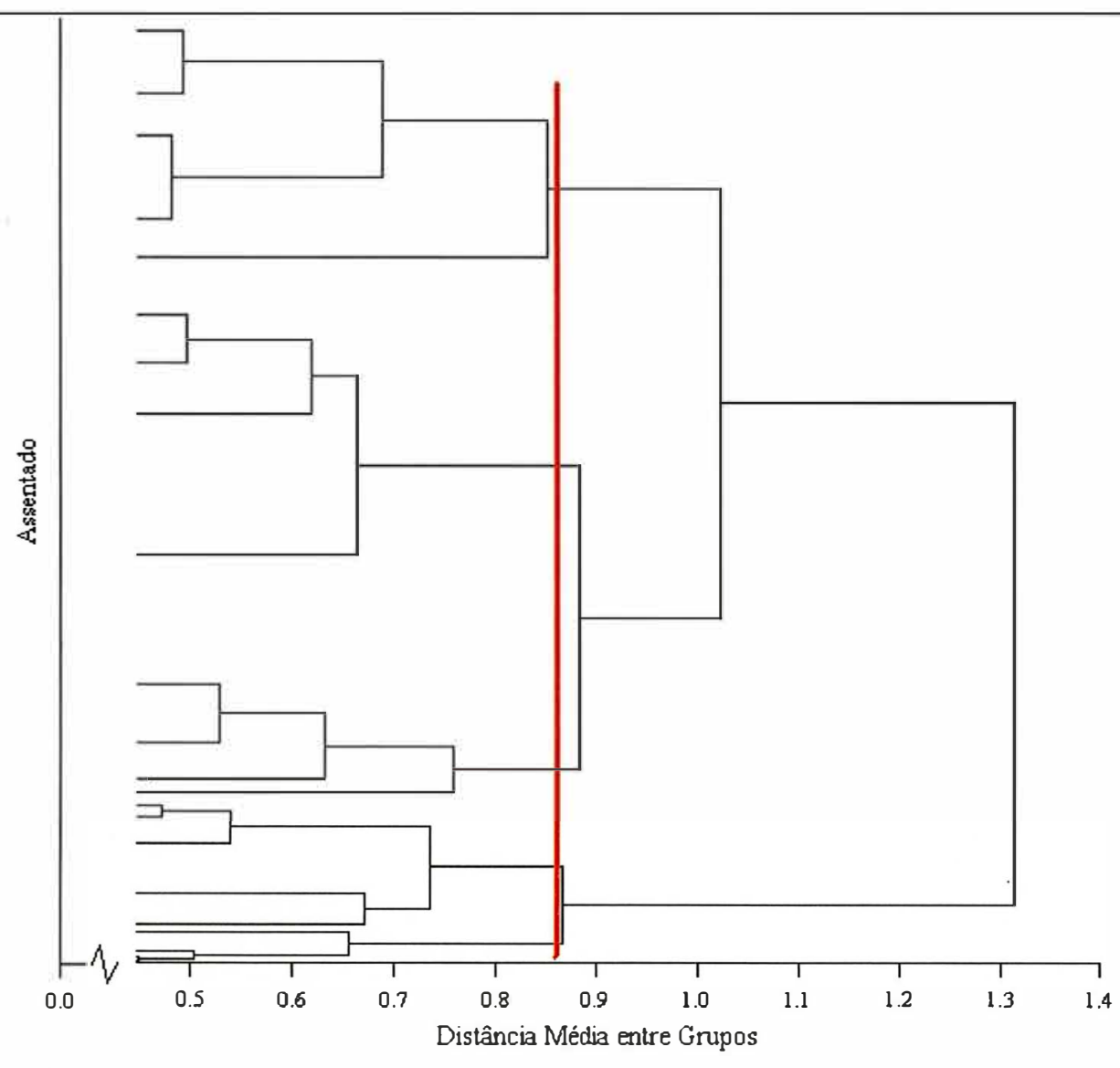

Figura 28 - Dendograma resultante da análise de agrupamento com distância de corte demarcada em 0,8517, conforme sugerido pela estatística Pseudo- $\mathrm{t}^{2}$ 
Não se objetiva a identificação dos assentados que compõem cada grupo, mas a formação de grupos que representem os diversos modelos de capacitação encontrados nos assentamentos.

O passo seguinte é a caracterização dos grupos formados, inicialmente através da freqüência em cada classe, Figura 29.

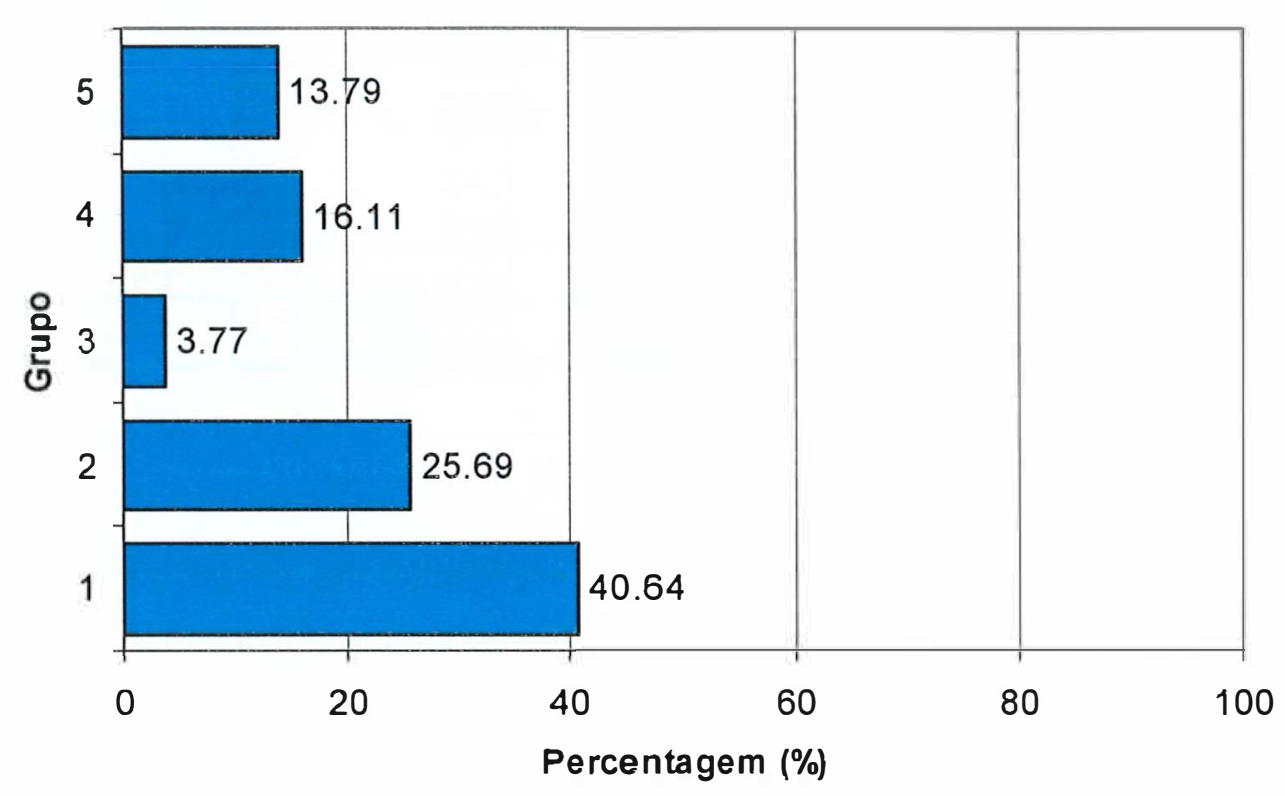

Figura 29 - Proporção de assentados em cada grupo formado a partir dos dados de capacitação (N: 689)

Observa-se a formação de um grande grupo que congrega 280 assentados (Grupo 1) ou $40,64 \%$ da amostra; um segundo grupo com $25,69 \%$ da amostra (177 assentados) e 3 grupos pequenos, cada um com menos que $20 \%$ da amostra mas que se mostra uniforme em relação aos critérios de agrupamento de capacitação.

Cada um dos grupos caracteriza um estágio diverso em relação à capacitação, o que pode ser identificado através das características médias dos grupos, Figura 30. 


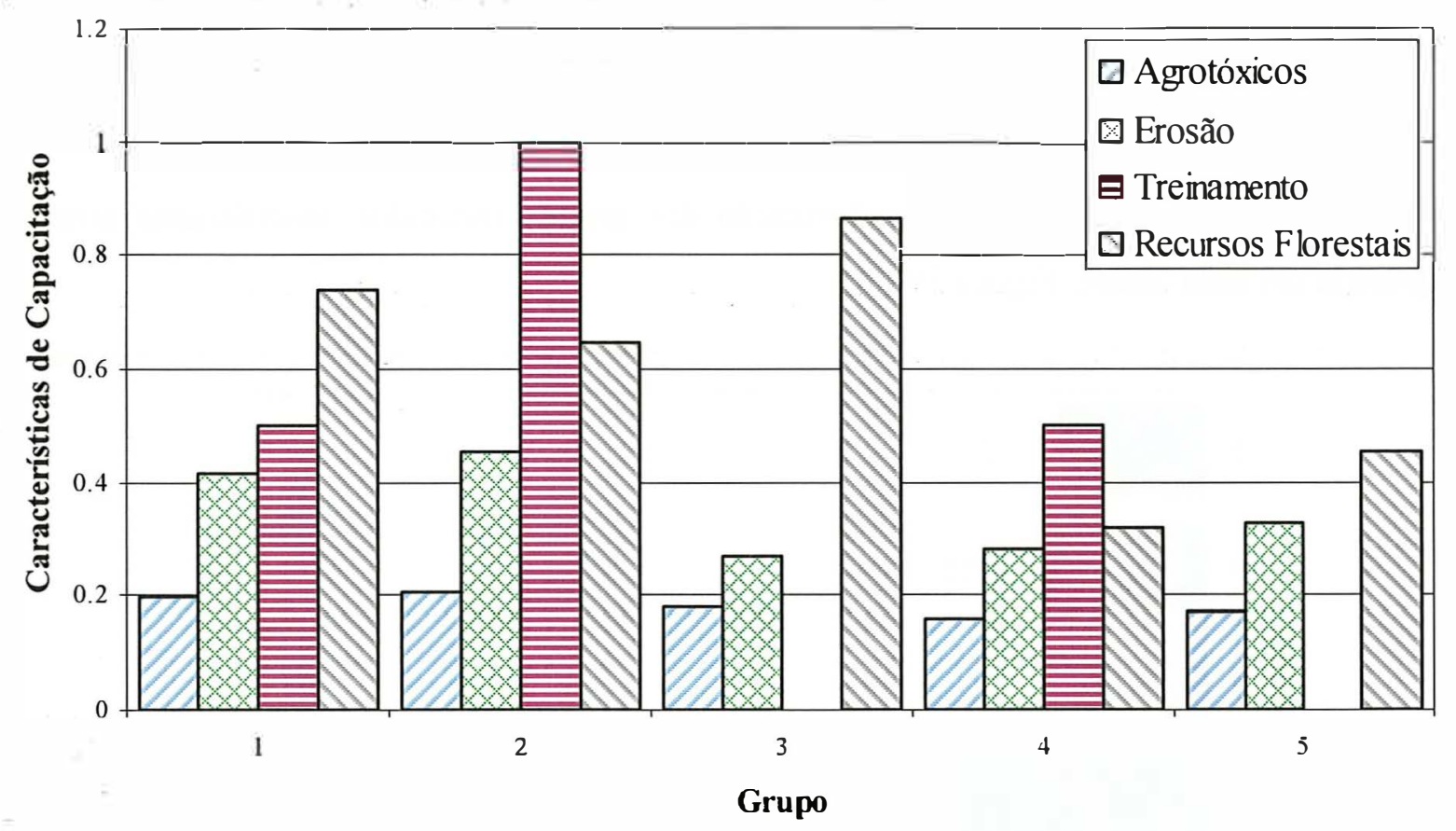

Figura 30 - Características médias de cada fator de capacitação nos grupos formados (N: 689)

Os grupos 1 e 2 se caracterizam, de forma geral, por um maior grau de capacitação que a dos assentados dos grupos 3, 4 e 5. Entre eles, a grande diferença é a de treinamento, mais efetiva, em média, nos assentados do grupo 2 que do grupo 1 . Em relação à capacitação para uso de agrotóxicos e erosão o grupo 2 é pouco mais capacitado ao passo que os do grupo 1 compensam com uma maior capacitação no uso de recursos florestais.

O grupo 3 aparece como o terceiro mais capacitado pois apesar não ter passado por treinamentos apresenta um grau de capacitação para uso de recursos florestais muito maior que os grupos 4 e 5 e tendo capacitação para uso de agrotóxicos e combate à erosão não muito inferiores.

Por fim, o Grupo 5 será tratado como mais capacitado que o Grupo 4 pois apresenta níveis maiores nos itens que denotam capacitação efetiva (Uso de Agrotóxico, Combate a Erosão e Uso de Recursos Florestais) ao passo que a participação em treinamentos, maior no Grupo 4, é potencial.

A indicação de que o grau de capacitação denota alterações na percepção ambiental seria interessante para se estabelecer um vínculo efetivo entre os dois fatores, à exemplo da indicação observada no caso da educação. 
Sendo assim principiou-se a análise através da seleção das variáveis ambientais com poder discriminante das classes de capacitação previamente constituídas. Os resultados da análise de seleção de variáveis discriminantes realizado através do procedimento stepdisc é aprentado em seguida, Tabela 16.

Tabela 16 - Resultado do processo de seleção de variáveis discriminantes para variável classificatória Grupo de Capacitação

\begin{tabular}{|c|c|c|c|c|c|}
\hline \multirow[b]{2}{*}{ Passo } & \multirow[b]{2}{*}{ Variável } & \multirow[b]{2}{*}{$\mathrm{R}^{2}$ Parcial } & \multicolumn{3}{|c|}{ Valores - p } \\
\hline & & & $\mathrm{F}$ & $\begin{array}{l}\text { Wilk's } \\
\text { Lambda }\end{array}$ & $\begin{array}{c}\text { Averaged } \\
\text { Square } \\
\text { Canonical } \\
\text { Correlation }\end{array}$ \\
\hline 1 & IIM & 0,0688 & $<, 0001$ & $<, 0001$ & $<<, 0001$ \\
\hline 2 & IGD & 0,0331 & 0,0002 & $<, 0001$ & $<, 0001$ \\
\hline 3 & ICA & 0,0178 & 0,0187 & $<, 0001$ & $<, 0001$ \\
\hline 4 & IRH & 0,0206 & 0,0084 & $<, 0001$ & $<, 0001$ \\
\hline 5 & IRF & 0,0123 & 0,0862 & $<, 0001$ & $<, 0001$ \\
\hline
\end{tabular}

Apenas o indicador IES (Índice de Percepção de Erosão do Solo) não tem poder significativo para discriminação dos grupos de capacitação em pelo menos um dos testes no nível de significância de $5 \%$.

Todos os demais índices têm poder discriminante e, por isto, podem ser usados no desenvolvimento de um critério discriminante.

Parte-se então para o estudo da suposição de multinormalidade o que validaria a utilização de um método discriminante paramétrico, Tabela 17.

Tabela 17 - Teste de normalidade univariada de Shapiro-Wilk e testes de Mardia e de HenzeZirkler para multinormalidade dos índices IRF, IRH, IES

\begin{tabular}{cccc}
\hline Variável & Teste estatístico & & Valor-p \\
\cline { 2 - 2 } IRF & W de Shapiro-Wilk & & $<, 0001$ \\
ICA & W de Shapiro-Wilk & & $<, 0001$ \\
IIM & W de Shapiro-Wilk & & $<, 0001$ \\
IRH & W de Shapiro-Wilk & & $<, 0001$ \\
IGD & W de Shapiro-Wilk & & $<, 0001$ \\
IRF & W de Shapiro-Wilk & $<, 0001$ \\
Sistema & Assimetria de Mardia & $<, 0001$ \\
& Curtose de Mardia & & $<, 0001$ \\
& T de Henze-Zirkler & & $<, 0001$ \\
\hline
\end{tabular}


110

Não há indícios que permita concluir que a idéia de multinormalidade é razoável, e nenhuma das variáveis também se mostra normalmente distribuída.

Conclui-se pela inadequação da aplicação de técnicas que dependam da multinormalidade, inclusive técnicas discriminantes, por isto, serão aplicadas técnicas nãoparamétricas. A análise discriminante principia com as distâncias generalizadas pareadas entre os grupos de escolaridade. A matriz de distâncias é utilizada em uma análise de agrupamento e posteriormente, testes multivariados foram aplicados para comparar a composição dos grupos, Figura 31.

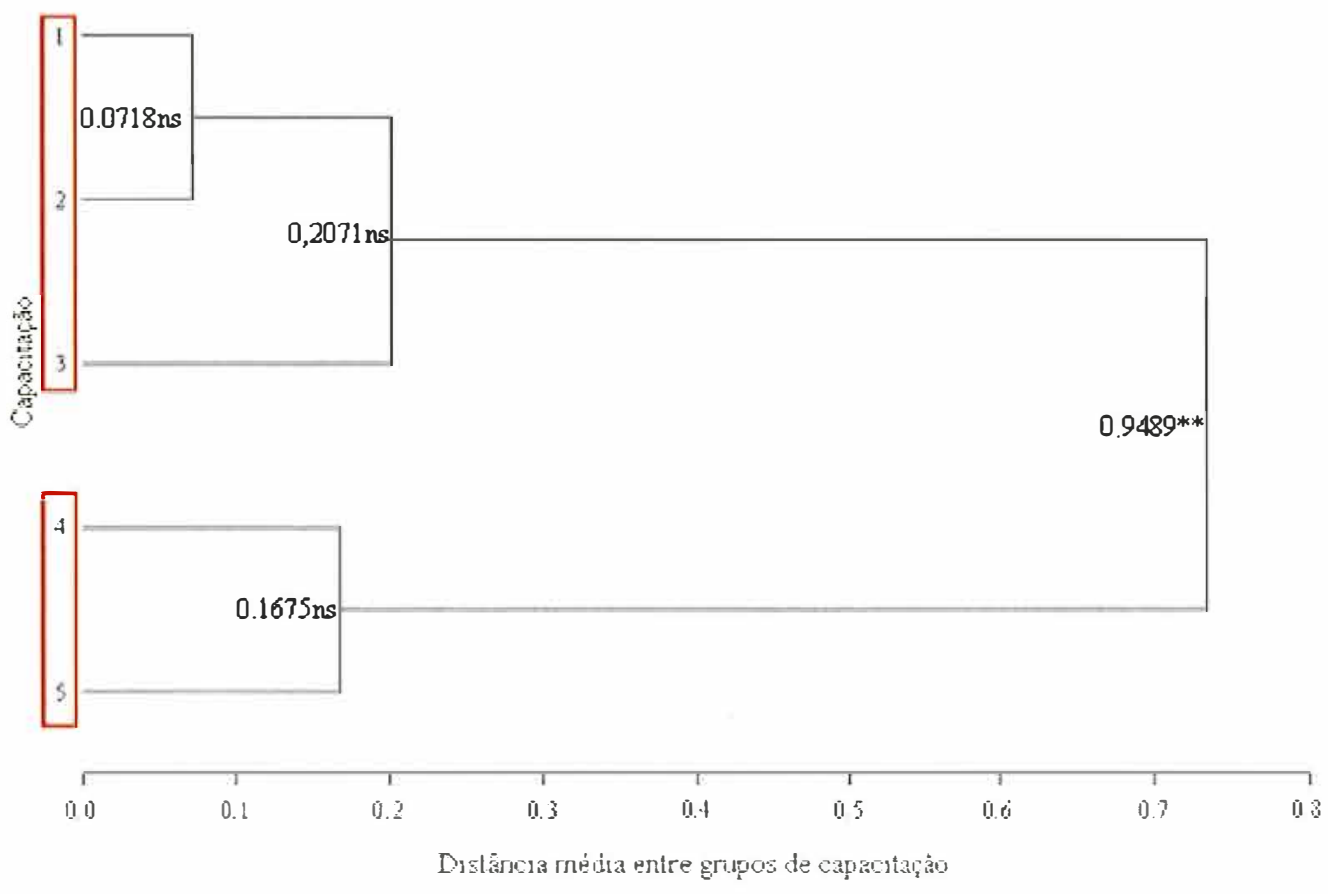

Figura 31 - Distâncias entre grupos de capacitação e resultado mais significativos dentre os testes multivariados(Traço de Pilai, Lambda de Wilk, Traço de Hotelling-Lawley e Raiz máxima de Roy) para os estratos - ns indica distância não significativa no nível de $5 \%, *$ indica distância significativa a $5 \%$ e ** a $1 \%$

Somente se observam diferenças entre os grupos de maior e menor capacitação, não havendo diferença significativa entre os grupos mais próximos o que evidencia, também que a opção por programas esparsos de capacitação terão pouca influência na percepção ambiental.

Os grupos 4 e 5, menos capacitados de acordo com os critérios estabelecidos totalizam $66,33 \%$ da população enquanto que os demais totalizam $33.67 \%$. 


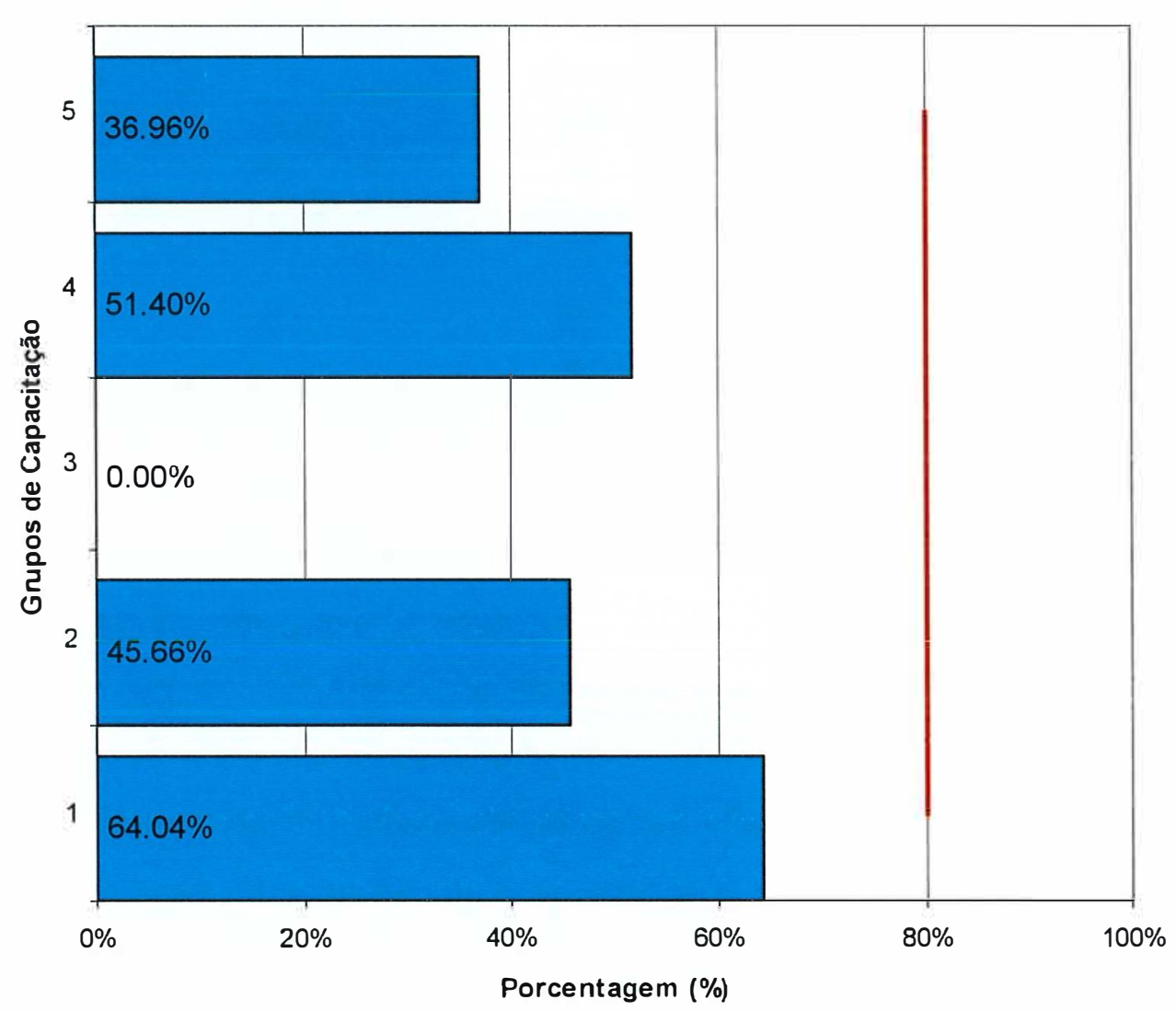

Figura 32 - Taxas de erro calculadas com base no processo de reclassificação dos dados dos índices de percepção e interação ambiental. A Faixa vermelha representa a probabilidade de erro no caso da classificação aleatória $(85,71 \%)$

Em nenhuma categoria, a taxa de erros suplanta o que seria esperado em condição aleatória, o que significa que o uso da técnica é eficiente, apesar das taxas de erro serem bastante grandes, mas o objetivo da técnica não é a predição, mas o estudo da associação da capacitação com a percepção ambiental.

\subsection{Estimativas das necessidades de Capacitação e Educação}

Uma vez determinada a existência de associação entre a percepção ambiental e as categorias de educação e capacitação, parte-se para a quantificação destas condições como forma de apoio de apoio à decisão para implantação de ações de educação, capacitação e financiamento.

Para tanto, uma tabela de dupla entrada permitirá o estudo das proporções de assentados em cada uma das diversas situações de interesse, Tabela 18. 
112

Tabela 18 - Proporção de assentados nos diversos estratos de capacitação e educação

\begin{tabular}{|c|c|c|c|c|}
\hline \multirow[b]{2}{*}{ Capacitação } & \multicolumn{3}{|c|}{ Educação } & \multirow[b]{2}{*}{ Total } \\
\hline & Alta & Média & Baixa & \\
\hline \multirow{2}{*}{ Alta } & 10 & 107 & 366 & 483 \\
\hline & 1,45 & 15,53 & 53,12 & 70,1 \\
\hline \multirow{2}{*}{ Baixa } & 3 & 27 & 176 & 206 \\
\hline & 0,44 & 3,92 & 25,54 & 29,9 \\
\hline \multirow[t]{2}{*}{ Total } & 13 & 134 & 542 & 689 \\
\hline & 1,89 & 19,45 & 78,66 & \\
\hline
\end{tabular}

A análise da Tabela 18 possibilita a formação de três grupos distintos em relação à destinação de recursos para com vistas às melhorias ambientais. Há um grupo composto pelos assentados de Alto ou, pelo menos Médio nível educacional e alto grau de capacitação e que compõem $16,98 \pm 3,59 \%$, da população que poderiam receber financiamentos uma vez que a percepção ambiental é suficiente para compreensão da importância das áreas de preservação na sustentabilidade da produção rural e os mesmos já se encontram capacitados para a condução de processos de melhoria ambiental.

Apesar de altamente capacitados, um grupo composto por $53,12 \pm 3,59 \%$ da população não tem nível educacional que garanta a existência de conscientização ambiental, embora os mesmos estejam capacitados para a condução de processos de melhoria ambiental tais como a implantação de florestas nativas ou mesmo a condução do processo de produção agrícola sem que sejam gerados grandes riscos ambientais.

Este público, somado ao de baixa escolaridade e baixa capacitação deveriam receber, primordialmente, condição de aquisição de conhecimentos através de programas de educação. $\mathrm{O}$ total de pessoas dentro desta categoria que necessita de políticas educacionais é de $78,66 \% \pm$ $3,59 \%$.

A conseqüência da não compreensão dos motivos da preservação ambiental podem ser a baixa motivação para adesão espontânea a programas de financiamento para melhoria ambiental, a não adesão a práticas que objetivem a sustentabilidade.

Por fim, há necessidade da implementação de políticas de capacitação para 4,36\% \pm $3,59 \%$ da população. Note-se que neste caso, não estão sendo computados aqueles que 
necessitariam primeiramente de políticas educacionais, mas que também necessitam de políticas de capacitação, o que poderia ocorrer de maneira concomitante. 



\section{CONCLUSÕES}

- A percepção em relação à temática ambiental dos beneficiários da reforma agrária não é uniforme no Estado de São Paulo.

- De acordo com a temática ambiental o grau de percepção é diferente.

- Os assentamentos são heterogêneos em relação aos problemas ambientais e isto é fruto mais da história de cada um e das condições ambientais preliminares à sua implantação que da própria ação antrópica após o assentamento.

- Objetivando a melhoria ambiental dos assentamentos, $16,98 \pm 3,59 \%$ dos assentados do Estado de São Paulo necessitam de financiamentos destinados diretamente à implantação de projetos de melhoria ambiental, não sendo necessários para este grupo, investimentos em Educação ou Capacitação.

- Objetivando a melhoria ambiental dos assentamentos, $4,36 \% \pm 3,59 \%$ dos assentados do Estado de São Paulo necessitam, antes dos financiamentos, de programas de capacitação tanto para a implementação de projetos de melhoria ambiental como da própria produção agrícola com objetivo de se mitigar os riscos ambientais.

- Objetivando a melhoria ambiental dos assentamentos do Estado de São Paulo, 78,66\% $\pm 3,59 \%$ dos assentados do Estado de São Paulo necessitam de investimentos em educação sendo que 53,12 $\pm 3,59 \%$ não necessita de investimentos com finalidade de capacitação, mas exclusivamente educação enquanto que $25,54 \% \pm 3,59 \%$ necessitam de educação e capacitação. 



\section{REFERÊNCIAS}

ANICE, C. Fórum Social Mundial 2002. Oficina: Função socioambiental da terra: reforma agrária e meio ambiente. In: ESTERCI, E.; VALLE, R. S. T. (Org.). Reforma Agrária e Meio Ambiente. São Paulo: Instituto Socioambiental, 2003.191p.

AMSBERG, J. von. Public policies to reduce rural poverty a selective assessment. In: WORLD BANK STAFF. Rural Poverty Alleviation in Brazil: Toward an Integrated Strategy. Herndon, VA, USA: World Bank Publications, 2003. 280p.

ASSUNÇÃO, J.J.; MAITREESH G. Can unobserved heterogeneity in farmes ability explain the inverse relationship between farm size and productivity. Economics Letters, Amsterdam, v.80, p.189-194, 2003.

BARTELMUS, P. Unveiling wealth. On Money, Quality of Life and Sustainability. Secaucus, NJ, USA: Kluwer Academic Publishers, 2002. 240p.

BARTHOLO JÚNIOR, R.S.; BURSZTYN, M. Prudência e Utopismo: Ciência e Educação para a Sustentabilidade In: BURSZTYN, M. Ciência, Ética e Sustentabilidade. Desafios ao Novo Século, Brasília: Edições UNESCO Brasil, 2001. 192 p.

BATISTA FILHO, M. Da fome à segurança alimentar: retrospecto e visão prospectiva. Brasil: Cadernos de Saúde Pública, Rio de Janeiro: Escola Nacional de Saúde Pública, Fundação Oswaldo Cruz, 2004. 3 p.

BEDUSCHI FILHO, L.C. Assentamentos rurais e conservação da natureza: do estranhamento à ação coletiva. São Paulo:Iglu:FAPESP, 2003. 104 p.

BEEDEL, J. D. C.; REHMAN, T. Explaining farmers' conservation behaviour: Why do farmers behave the way they do ? Journal of Environmental Management, Berkeley, v.57, p.165-176, 1999.

BERGAMASCO, S.M.P.P.; NORDER, L.A.C. A alternativa dos assentamentos rurais: organização social, trabalho e política. São Paulo: Terceira Margem, 2003. 192 p.

BOER, W. F.; BAQUETE, D. S. Natural resource use, crop damage and attitudes of rural people in the vicinity of the Maputo Elephant Reserve, Mozambique. Environmental Conservation, Cambridge, v.25, n.3, p.208-218, 1998. 
118

BRASIL. Constituição. Constituição da República Federativa do Brasil: Texto Consolidado até a emenda $\mathrm{n}^{\circ} 47$ de 5/07/2005. Disponível em: <http://www.senado.gov.br/sf/legislacao/const/>. Acesso em: 15 jun. 2005.

BRASIL. Leis, decretos, etc. Lei n ${ }^{\circ} 4504$ de 30 de novembro de 1964. Dispõe sobre o Estatuto da Terra, e dá outras providências.

BUARQUE, C. Os Instrangeiros. Brasil: Editora Garamond, 2004. 186 p.

BURSZTYN, M. Ciência, Ética e Sustentabilidade. Desafios ao Novo Século, Brasília: Edições UNESCO Brasil, 2001. 192 p.

CARMO, M. S. Assentamentos Rurais em São Paulo e Agricultura Sustentável em Um Enfoque de Redirecionamento de Perspectivas. In: BERGAMASCO, S. M. P. P.; AUBRÉE, M.; FERRANTE, V. L. S. B. (Org.). Dinâmicas familiar, produtiva e cultural nos assentamentos rurais de São Paulo. São Paulo: INCRA, 2003, p. 295-319.

CARVALHO, I. C. M. Educação ambiental crítica: nomes e endereçamentos da educação ambiental. In: LAYRARGUES, P. P. (Org.). Identidades da Educação Ambiental Brasileira. Brasília: Ministério do Meio Ambiente, 2004, p. 13-24.

CASTELLO, L. A. Percepção em Análises Ambientais. O Projeto Mab/Unesco Em Porto Alegre. In: DEL RIO, V.; OLIVEIRA, L. (Org.). Percepção Ambiental. A Experiência Brasileira. São Paulo: Studio Nobel/Editora da UFSCar, 1996, p. 21-35.

COCHRAN, W.G. Sampling Techniques. 3rd ed. New York: John Wiley, 1977. 429 p.

COSTA, C. M. O.; BERGAMASCO, M.P.P.B. Processo de Organização da Produção em Assentamentos Rurais no Brasil: A Fazenda Pirituba/SP. In: BERGAMASCO, S. M. P. P.; AUBRÉE, M.; FERRANTE, V. L. S. B. (Org.). Dinâmicas familiar, produtiva e cultural nos assentamentos rurais de São Paulo. São Paulo: INCRA, 2003, p. 125-155.

CULLEN JÚNIOR, L.; BODMER, R. E. ; PÁDUA, C. V. . Effects of hunting in habitat fragments of the Atlantic Forests, Brazil. Biological Conservation, Amsterdam, v. 95, p. 49-56, 2000. 
CULLEN JÚNIOR, L. Agroforestry Benefit Zones: A Tool for the Conservation and Management of Atlantic Forest Fragments, São Paulo, Brazil. Natural Areas Journal, Bend, v. 21, n.4, p. 345-355, 2001.

DIAS, G.L.S.; BARROS, A.L.M. Dynamics of the Brazilian Small Farm Sector. In: WORLD BANK STAFF. Rural Poverty Alleviation in Brazil : Toward an Integrated Strategy. Herndon, VA, USA: World Bank Publications, 2003. 280p.

DIEDERICHSEN, A.T.B. Influência da atitude conservacionista e da legislação ambiental na conservação de fragmentos florestais. 2003. 46 p. Dissertação (Mestrado em Ciência Ambiental) Universidade de São Paulo. São Paulo, 2003.

DITT, E. H. ; MANTOVANI, W.; VALLADARES-PÁDUA, C.; BASSI, C. Entrevistas e aplicação de questionários em trabalhos de conservação. IN: CULLEN JÚNIOR, L.; RUDRAN, R.;

VALLADARES-PÁDUA, C. Métodos de estudos em Biologia da Conservação \& Manejo da Vida Silvestre. Curitiba: Ed. da UFPR; Fundação O Boticário de Proteção à Natureza, 2003. p.631-647.

FAO/INCRA. Novo Retrato da Agricultura Familiar - O Brasil Redescoberto. In: GUANZIROLI, C. E.; CARRIM, S.E.C.S.(Org.). Brasília: FAO/INCRA,2000. 74 p.

FENIMORE, S. C.; CULLEN JÚNIOR, L. Projeto Abraço Verde: A Pratice-Based Approach to Brazilian Atlantic Forest Conservation. Endangered Species UPDATE, Ann Arbor, v. 19, n.4, p. 179-185, 2002.

FERREIRA, F.; LANJOUW, P.; NERI, M. The Urban Poor in Brazil in 1996: A New Poverty Profile Using PPV, PNAD and Census Data. Programa para el Mejoramiento de las Encuestas y la Medición de las Condiciones de Vida En América Latina y el Caribe. 1999. Buenos Aires. Anais ..., Buenos Aires: CEPAL/INEGI, 1999. p. 485-513.

GORDON, L. Brazil's Second Chance : En Route Toward the First World. Washington, DC, USA: Brookings Institution Press, 2001. 261 p.

GRYNSZPAN, D. Educação em saúde e educação ambiental: uma experiência integradora. Brasil: Cadernos de Saúde Pública - Escola Nacional de Saúde Pública, Rio de Janeiro: Fundação Oswaldo Cruz, 2004. 7p.

GUATTARI, F. As Três Ecologias. 13. ed. Campinas: Papirus Editora, 1990. 56p. 
120

GUEDES PINTO, L.C. Política agrícola, reforma agrária e a preservação do meio ambiente. In:

CONGRESSO BRASILEIRO DE CIÊNCIA DO SOLO, 21., 1988, Campinas. Anais... Campinas:

Sociedade Brasileira de Ciência do Solo, 1988. p. 213-216. Disponível em:

$<$ http://www.rc.unesp.br/igce/ceapla/biblioteca/agricultura.html>. Acesso em: 15 out. 2005.

HENDERSON, H. Caminhos de Transição para a Sustentabilidade: Informação, Energia e Matéria.

In: VIEIRA, L. L. Novo caminho para o Brasil no século XXI. Brasília: UNESCO BRASIL, 2004. $141 \mathrm{p}$.

HENZE, N.; ZIRKLER, B. A Class of Invariant Consistent Tests for Multivariate Normality.

Communications in Statististics:Theory and Methods, Hamilton, Ontário, Canadá,v.19, n.10, p. 3595-3617, 1990.

HOFFMANN, R. Distribuição da Renda e da Posse da Terra no Brasil. Reforma Agrária, Campinas, v. 2, n. $8 / 9$, p. 2-12, 1972.

ITESP. Projetos de Assentamento em que o ITESP implementa projetos de desenvolvimento. São Paulo: Fundação Instituto de Terras do Estado de São Paulo “José Gomes da Silva”, 2005. 1 p. Disponível em <http://www.itesp.sp.gov.br/acprogres/tabelaassentamentos.htm>. Acesso em: 15 jun. 2005.

JUNQUEIRA, M. As terras devolutas na reforma agrária. São Paulo: Editora Revista dos Tribunais, 1964. $140 \mathrm{p}$.

KENNY, M. Planning Sustainability : Implications of Sustainability for Public Planning Policy. London, UK: Routledge, 1999.241p.

KING, R. Managing for Sustainability. Broadstairs, Kent, UK: Scitech Educational, 2002. 112 p.

KLUG, I. L. F.; SHIMBO, J.Z.; ALVES, M.C.; SPAROVEK,G. Impactos sobre recursos florestais no assentamento rural Pirituba II, municípios de Itapeva e Itaberá, SP. In: SIMPÓSIO "IMPASSES E DILEMAS DA POLÍTICA DE ASSENTAMENTOS (BALANÇO DE 20 ANOS DE SUA TRAJETÓRIA", 2005, Araraquara. Resumos ... Araraquara: UNIARA, 2005. p. 49.

LEAL, J. Tabelas Estatísticas Obtidas por Computador Eletrônico. São Paulo: Edição do Autor, $1981.41 \mathrm{p}$. 
LIMA, J. F.; GOMES, H. B.; CULLEN JÚNIOR, L.; BELTRAME, T. P.; RODELLO, C. M. Café com Floresta: Interligando a Paisagem Fragmentada no Pontal do Paranapanema - SP. In: CONGRESSO BRASILEIRO DE AGROECOLOGIA, SEMINÁRIO INTERNACIONAL SOBRE AGROECOLOGIA, 4. SEMINÁRIO ESTADUAL SOBRE AGROECOLOGIA, 6. 2003, Porto Alegre. Anais... Porto Alegre: URGS, 2003. 1 v.

MACDOWELL, C. The Multivariate Modelling and Prediction of Farmers' Conservation Behaviour Towards Natural Ecosystems. Journal of Environmental Management, Berkeley, v. 28, p. 185-210, 1989.

MAGALHÃES, R. Enfrentando a pobreza, reconstruindo vínculos sociais: as lições da ação da Cidadania contra a Fome, a Miséria e pela Vida, Cadernos de Saúde Pública, Rio de Janeiro, v. 18, p.121-132, 2002.

MALTHUS, T.R. An Essay on the Principle of Population: A View of its Past and Present Effects on Human Happiness; with Inquiry into Our Prospects Respecting que Future Removal or Mitigation of the Evils which It Occasions. 6rd. ed. London: John Murray, 1826. 172 p.

MARDIA, K. V. Aplications of some measures of multivariate skewness and kurtosis in testing normality and robustness studies, Sankhya B, Kolkata, v. 36, p. 115-128, 1974.

MARTINS, J.D.S. Reforma Agrária: O Impossível Diálogo. São Paulo: Editora da Universidade de São Paulo, 2000. 173 p.

MCDOWELL, C.; SPARKS, R. The Multivariate Modelling and Prediction of Farmers' Conservation Behaviour Towards Natural Ecosystems. Journal of Environmental Management, Berkeley, v. 28, p.185-210, 1989.

MEADOWCROFT, J. Planning for sustainable development: what can be learned from the critics? In: KENNY, M. Planning Sustainability : Implications of Sustainability for Public Planning Policy. London, UK: Routledge, 1999. 241p.

MICROSOFT CORPORATION. Microsoft Visual Basic, versão 6.0 - SP5, São Paulo, 1987. 1 CDROM.

MICROSOFT CORPORATION. Microsoft Access 2002, São Paulo, 2002. 1 CD-ROM. 
NASSAUER, J. I. Culture and changing landscape structure. Landscape Ecology, Minneapolis, v.10, n. 4, p.229-237, 1995.

NOORDWIJK, M. Plant nutrition: Its role in sustainability of simple and complex agro-ecosystems. In: HORST, W. J. Plant Nutrition. Food Security and Sustainability of Agro-Ecosystems through Basic and Applied Research. Hingham, MA, USA: Kluwer Academic Publishers, 2001. 1082 p.

OMETTO, A. M. H.; HOFFMANN, R.; ALVES, M.C. A segregação por gênero no Estados de São Paulo e Pernambuco. Economia Aplicada, São Paulo,v.1, n. 3, p. 393-423, 1997.

OMETTO, A. M, H; HOFFMANN, R.; ALVES, M.C. Participação da Mulher no Mercado de Trabalho: Discriminação em Pernambuco e São Paulo. Revista Brasileira de Economia, Rio de Janeiro, v.53, p. $287-322,1999$.

PÁDUA, C.V.; PÁDUA, S.M.; CULLEN JÚNIOR, L. Within and Surrounding the Morro do Diabo State Park: biological value, conflicts, mitigation and sustainable development alternatives.

Environmental Science \& Policy, Oxford, v. 5, p. 69-78, 2002.

SAS INTITUTE INC., The SAS System, versão 8.02. SAS Institute Inc, 1999. Cary:NC. 5 CD-ROM. SAS INSTITUTE INC., SAS/STAT User's Guide, Version 6, 4th ed. Cary, NC: SAS Institute Inc., 1989. v.1. 943 p.

SAS INSTITUTE INC., SAS/STAT User's Guide, Version 6, 4th ed. Cary, NC: SAS Institute Inc., 1989. v.2. 846 p.

SOKAL, R.R.; MICHENER, C.D. A Statistical Method for Evaluating Systematic Relationships, University of Kansas Science Bulletin, Lawrence, n. 38, p. 1409-1438, 1958.

SPAROVEK, G. A qualidade dos assentamentos da reforma agrária brasileira. São Paulo: Páginas e Letras, 2002. 204 p.

STRACHMAN, M. A.; TAMBELINI, M. Associação Nacional de Pós-Graduação de Pesquisa em Ambiente e Sociedade. In: ENCONTRO DA ANPPAS, 2. Percepção Ambiental dos Pequenos Agricultores da região de Araraquara. Indaiatuba, 2004. Disponível em <http://www.anppas.org.br/encontro/segundo/Papers/GT/GT05/marina strachman.pdf>. Acesso em: 08 maio, 2005. 
TREVISAN, S. D. P. Reforma Agrária e Meio Ambiente. Revista Ciências Agrárias, Belém, n.32, jul/dez. p.65-80, 1999.

TUCCI, C. E. M. Gestão da água no Brasil. Brasília: UNESCO Brasil, 2004. 56p.

VALLADARES-PÁDUA, C. B.; PÁDUA, S. M.; CULLEN JÚNIOR, L. Within and surrounding the Morro do Diabo State Park: biological value,conflicts, mitigation and sustainable development alternatives. Environmental Science \& Policy, Oxford, v. 2, p. 69-78, 2002.

VIOTTI, E. B. Ciência e tecnologia para o desenvolvimento sustentável brasileiro. In: BURSZTYN, M. Ciência, Ética e Sustentabilidade. Desafios ao Novo Século. Brasília: Edições UNESCO Brasil, 2001. $192 \mathrm{p}$.

WILSON, G.A. A Survey on Attitudes of landholders to Native Forest on Farmland. Journal of Environmental Management, Berkeley, v. 34, p.117-136, 1992.

WORLD BANK STAFF. Rural Poverty Alleviation in Brazil: Toward an Integrated Strategy. Herndon, VA, USA: World Bank Publications, 2003. 280p. 

ANEXO A:

1. Informações Iniciais

Data da entrevista: / /2005

1.1 Nome do Entrevistador:

1.2 Nome do Entrevistado:

1.3 Assentamento:

1.4 Número do Lote:

1.5. Entrevistado é o titular?

Horário de Início (24h):

$\mathrm{H}$

M

ar? $\square \operatorname{Sim} \square$ Não $\square$ Não sei

\section{Informações para Estratificação}

2.1 Chegada à região:

$\square$ Antes $\square$ Durante $\square$ Após a implantação do assentamento

2.2 Há quanto tempo está na região do assentamento?:___ anos ou desde

2.3 Antes de ser assentado foi:

\begin{tabular}{|c|c|c|c|}
\hline Arrendatário & Empregad & m Fazenda & Outro: \\
\hline$\square$ Nesta região $\square$ Outra região & $\square$ Nesta região & $\square$ Outra região & $\square$ Nesta região \\
\hline
\end{tabular}

2.4 Há quanto tempo trabalha no meio rural ?: _ anos ou desde _ $\square$ desde que nasceu/criança

2.5 Participou de algum movimento: $\square \operatorname{Sim}^{*} \square$ Não ${ }^{*}$ Qual liderança:

*2.6 Ainda participa: $\square \operatorname{Sim} \square$ Não

2.7 Foi acampado: $\square \operatorname{Sim} \square$ Não Tempo acampado:__ anos ou desde

2.8 Município em que nasceu:

2.9 Município que morou antes de ser assentado:

2.10 Sexo do entrevistado:

2.11 Sexo do titular (somente se não entrevistando o titular):

2.12 Idade do entrevistado (anos):

\section{Escolaridade Formal}

3.1 Quem mora no lote e que foi mais longe nos estudos:

$\square$ Marido $\square$ Mulher $\square$ Filho/enteado $\square$ Outro:

3.2 Quem foi mais longe nos estudos está sendo entrevistado ?

3.3 Qual a escolaridade?

Não estudou e não lê ou escreve (ou apenas assina o nome)

Lê e escreve

Concluiu a $4^{\mathrm{a}}$ série

Concluiu a $8^{\mathrm{a}}$ série

Concluiu o Ensino Médio (Colegial)

Profissional técnico em:

Graduação em:

$\begin{array}{cc}\square \text { Sim } & \square \text { Não } \\ \text { Maior escolaridade } & \text { Entrevistado } \\ \square & \square \\ \square & \square \\ \square & \square \\ \square & \square \\ \square & \square \\ \square & \square \\ \square & \square\end{array}$




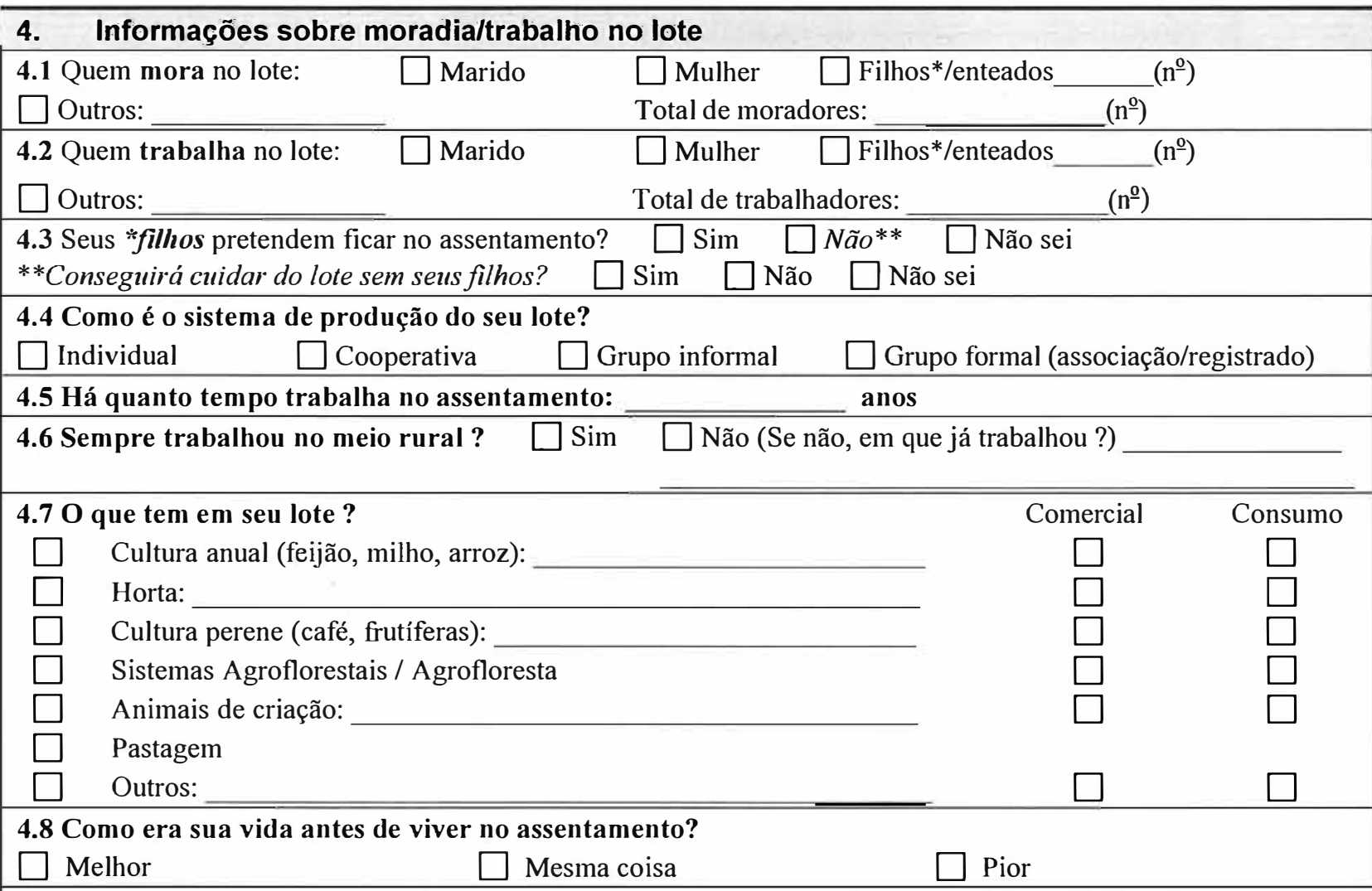

4.9 Quais são os três maiores problemas do assentamento?

\section{Informações sobre atitude conservacionista}

\subsection{Há alguma mata/floresta no assentamento ?}

$\square \operatorname{Sim}^{*}$

Não

Não sei

* Por que motivos?

$\square$ A área não serve para outros usos

Barreira contra o vento

$\square$ Área de proteção da natureza

$\square$ Proteção dos solos e da água

Não pode desmatar

$\square$ Não sei 


\begin{tabular}{|c|c|c|c|c|}
\hline *5.2 Você já & $\begin{array}{c}\text { Aproveitou } \\
\square \\
\square \\
\square \\
\square \\
\square \\
\square \\
\square \\
\square \\
\square \\
\square \\
\square\end{array}$ & $\begin{array}{l}\text { a mata ou floresta para: } \\
\text { cabo de enxada } \\
\text { lenha para fogão } \\
\text { lenha para carvão } \\
\text { Apicultura } \\
\text { madeira para mourão de cerca } \\
\text { madeira para construção } \\
\text { medicamentos e remédios caseiros } \\
\text { passear (lazer) } \\
\text { pasto para os animais } \\
\text { carne de caça } \\
\text { Outros, especificar: }\end{array}$ & $\begin{array}{c}\text { aproveita } \\
\square \\
\square \\
\square \\
\square \\
\square \\
\square \\
\square \\
\square \\
\square \\
\square\end{array}$ & $\begin{array}{c}\text { *se pudesse } \\
\square \\
\square \\
\square \\
\square \\
\square \\
\square \\
\square \\
\square \\
\square \\
\square\end{array}$ \\
\hline \multicolumn{5}{|c|}{ * Somente se a pessoa falar que não pode. } \\
\hline \multicolumn{5}{|c|}{$\begin{array}{l}\text { *5.3 Já viu alguém tirar árvores dessas áreas de mata ou floresta ? } \\
\square \operatorname{Sim} \quad \square \text { Não } \quad \square \text { Há muito tempo }\end{array}$} \\
\hline $\begin{array}{l}* 5.4 \text { Gostaria de s } \\
\square \text { Sim } \\
\square \text { Não }\end{array}$ & $\begin{array}{c}\text { substituir a } m \\
\text { O que? } \\
\text { Por que? }\end{array}$ & ata por outra coisa (uma lavoura, pastc & o...)? & $\cdot$ \\
\hline $\begin{array}{l}5.5 \text { Há nascente/ } \\
\square \operatorname{Sim}^{*} \quad[\end{array}$ & $\begin{array}{l}/ \text { minas d'águ } \\
\square \text { Não }\end{array}$ & $\begin{array}{l}\text { / rio / lago no assentamento ? } \\
\square \text { Não sei }\end{array}$ & & \\
\hline \multicolumn{5}{|c|}{ *5.6 O que há nas margens? } \\
\hline $\begin{array}{l}\text { 5.7 Existem dent } \\
\square \operatorname{Sim}^{*} \quad[\end{array}$ & \multicolumn{3}{|c|}{ 5.7 Existem dentro do assentamento, áreas protegidas por lei para proteção da natureza? } & \\
\hline \multicolumn{5}{|c|}{$\begin{array}{l}\text { 5.8 Sabe qual é a largura da faixa na beira de rios/nascentes/lagos que é determinada por lei para proteção } \\
\text { da natureza ? }\end{array}$} \\
\hline \multicolumn{5}{|c|}{ *5.9 São dados nomes para estas áreas de proteção da natureza? } \\
\hline
\end{tabular}


*5.10 Nessas áreas protegidas por lei para proteção da natureza pode-se (esclarecer quando se está falando da APP - Beira d'água e RL, somente se o entrevistado as diferencia).

$\begin{array}{llll}\text { Plantar árvores } & \square \mathrm{R} \square \mathrm{A} \square \mathrm{ND} & \text { Cultivar em baixo das árvores } & \square \mathrm{R} \square \mathrm{A} \square \mathrm{ND} \\ \text { Tirar árvores } & \square \mathrm{R} \square \mathrm{A} \square \mathrm{ND} & \text { Usar como pasto, mas com poucos animais } & \square \mathrm{R} \square \mathrm{A} \square \mathrm{ND} \\ \text { Cultivar } & \square \mathrm{R} \square \mathrm{A} \square \mathrm{ND} & \text { Não pode ser usada } & \square \mathrm{R} \square \mathrm{A} \square \mathrm{ND}\end{array}$

Retirar algumas árvores $\square \mathrm{R} \square \mathrm{A} \square \mathrm{ND}$

Anote $R$ (Reserva) se o entrevistado disser que pode na reserva, $A(A P P)$ se o entrevistado disse que só pode na $A P P$ e ND(Não diferencia), se disser que pode ser em qualquer lugar.

*5.11 Para quem se pede autorização para usar essas áreas:
IBAMA
$\square$
DPRN
INCRA
Polícia Florestal
ITESP
Prefeitura Municipal

\section{Uso de defensivo agrícola}

6.1 Você usa veneno/agrotóxico na sua cultura ou na criação ?

$\square \operatorname{Sim}^{*} \quad \square$ Não** $\square$ Não sei

*6.2 O veneno que você usa é perigoso?

**6.2 Os agrotóxicos são perigosos?

Para as pessoas que aplicam

$\square \operatorname{Sim}$

$\square$ Não

Não sei

Para as pessoas que comem os alimentos produzidos

$\square \operatorname{Sim}$

$\square$ Não

Não sei

Se cair nos rios, nascentes e lagos

$\square \operatorname{Sim}$

$\square$ Não

Não sei

Para os animais da criação

$\square \operatorname{Sim}$

$\square$ Não

Não sei

Para os animais silvestres

$\square \operatorname{Sim}$

$\square$ Não

Não sei

*6.3 Quando compra, aonde guarda os venenos?

Dentro de casa?

$\square \operatorname{sim}$

$\square$ Não

Não sei

Na garagem ou oficina?

$\square \operatorname{Sim}$

$\square$ Não

Não sei

Em um local onde só ficam os venenos?

$\square \operatorname{Sim}$

$\square$ Não

Não sei

Paiol, rancho

$\square \operatorname{Sim}$

$\square$ Não

Não sei

*6.4 Quantas vezes você lava a embalagem vazia?

*6.5 O que faz com a água da lavagem?

*6.6O que faz com as embalagens vazias?

$\square$ Reutiliza $\square$ Queima $\square$ Enterra $\square$ Devolve onde comprou $\square$ Outro:

$6.7 \mathrm{O}\left({ }^{*}\right.$ veneno que você usa) $\left({ }^{* *}\right.$ veneno) pode prejudicar a saúde da pessoa que está aplicando se:

Se a pessoa deixar o veneno escorrer na pele $\quad \square \operatorname{Sim} \quad \square$ Não $\quad \square$ Não sei

Se a pessoa encostar na planta logo depois da aplicação $\quad \square \operatorname{Sim} \quad \square$ Não $\quad \square$ Não sei

Se a pessoa sentir o cheiro do veneno

$\square \operatorname{Sim} \quad \square$ Não $\quad \square$ Não sei

Se a pessoa não se lavar depois da aplicação

$\square \operatorname{Sim} \quad \square$ Não $\square$ Não sei

6.8 Sabe o que é prazo de carência de um veneno ? $\square \operatorname{Sim} \quad \square$ Não

6.9 Quanto tempo depois da aplicação de um veneno a roça pode ser colhida?

$\square$ De um a três dias $\quad \square$ Depois da chuva $\square$ Outro (especificar):

$\square$ Depende do veneno e da cultura

Não sei 


6.10 Qual é a cor do rótulo do veneno mais perigoso ?
$\square$ Azul $\quad \square$ Verde $\quad \square$ Vermelho $\square$ Amarelo $\square$ Não sei

\section{Fauna silvestre}

7.1 Quais animais que não são de criação são vistos aqui no assentamento ?

1.

2.

3.

4.

5.

7.2 Há pessoas que caçam no assentamento ? $\square \operatorname{Sim}^{*} \quad \square$ Não $\square$ Não sei

*Pessoas do assentamento? $\square$ Sim* $\square$ Não $\square$ Não sei

*7.3 Qual é o motivo?
$\square$ Para comer $\square$ Por diversão $\square$ Para vender $\square$ Proteger lavoura/criação $\quad \square$ Não sei

7.4 Quanto a captura de animais vivos (pássaros, borboletas, ...) ?

Há pessoas que capturam animais no assentamento? $\square \operatorname{Sim}^{*} \quad \square$ Não $\square$ Não sei

*Pessoas do assentamento? $\square$ Sim* $\square$ Não $\square$ Não sei

*7.5 Se existir captura de animais vivos, qual é o motivo?

$\square$ Por diversão $\square$ Para vender $\square$ Para ter em casa (domesticar) $\square$ Não sei

\section{Recursos hídricos}

8.1 De onde vem a água usada em seu lote?

Rio

$\square \operatorname{Sim} \quad \square$ Não $\square$ Não sei

Poço freático (cacimba)

$\square \operatorname{Sim} \quad \square$ Não $\square$ Não sei

Poço artesiano

$\square \operatorname{Sim} \square$ Não $\square$ Não sei

Tem nascente/mina d'água dentro do lote

$\square \sin$

$\square$ Não

$\square$ Não sei

Serviço público

$\square \operatorname{Sim}$

$\square$ Não

$\square$ Não sei

Tem lagoa ou açude dentro do lote

$\square \operatorname{Sim}$

$\square$ Não

$\square$ Não sei

8.2 O que é feito com a água no assentamento ?

Açude $\square$ Sim $\square$ Não $\square$ Não sei

Para criação (animais)

$\square \operatorname{sim} \square$ Não $\square$ Não sei

Irrigação

$\square \operatorname{sim}$

$\square$ Não

$\square$ Não sei

Piscicultura

$\square \operatorname{sim} \square$ Não

$\square$ Não sei

Processamento da produção (fábrica)

$\square \operatorname{sim}$

$\square$ Não

$\square$ Não sei

8.3 Acha que há desperdício ou mau uso de água por parte dos assentados?

$\square \operatorname{Sim}$

$\square$ Não

$\square$ Não sei 


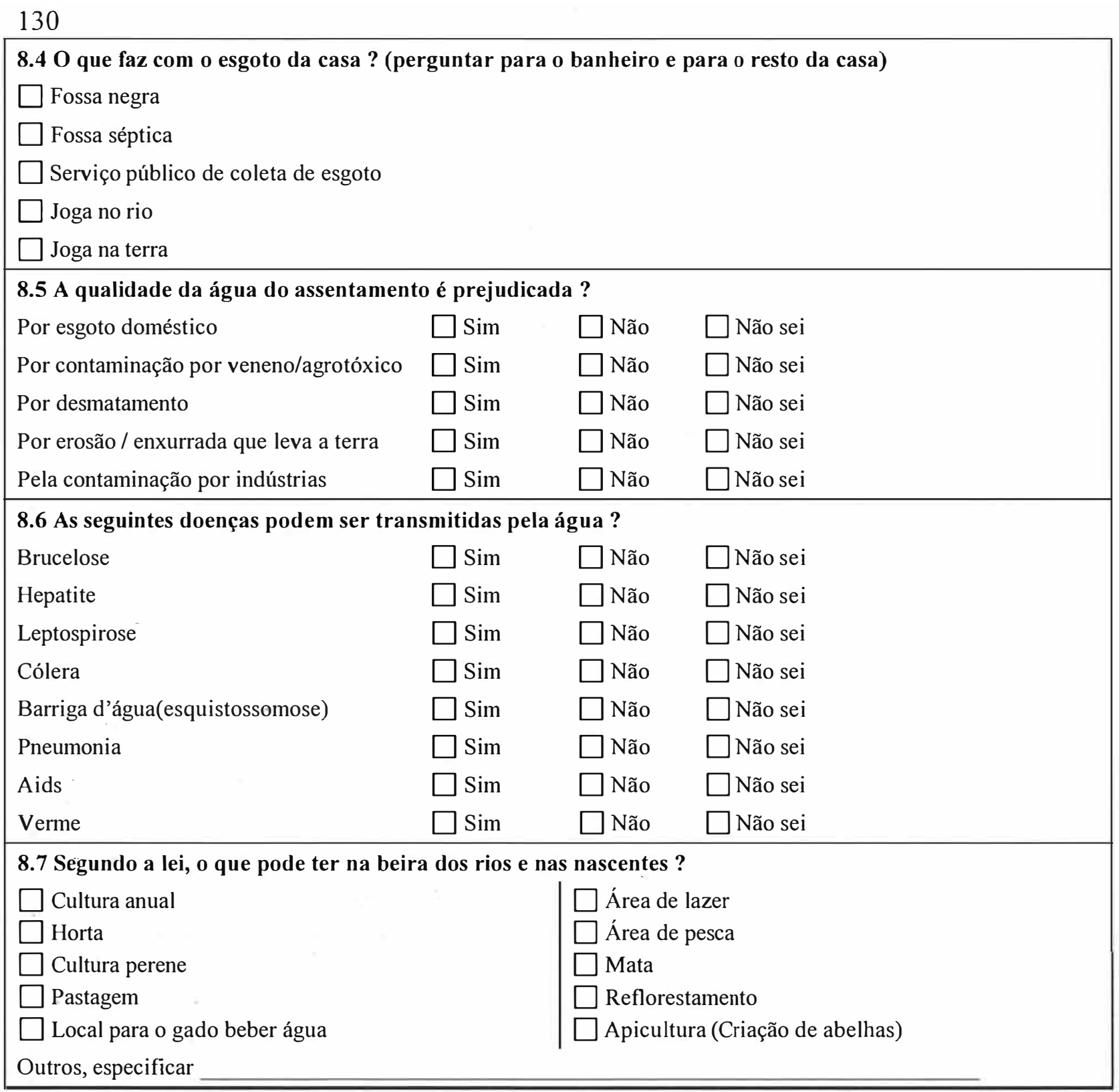




\section{Resíduos sólidos}

9.1 O que faz com o lixo gerado no lote?

Queima

$\square \operatorname{Sim}$

$\square$ Não

$\square$ Não sei

Coleta pública

$\square \operatorname{Sim}$

$\square$ Não

$\square$ Não sei

Compostagem

$\square \operatorname{Sim}$

$\square$ Não

$\square$ Não sei

Utilização na lavoura (adubo)

$\square \operatorname{Sim}$

$\square$ Não

Não sei

Reciclagem

$\square \operatorname{Sim}$

$\square$ Não

$\square$ Não sei

Enterra em vala

$\square \operatorname{Sim}$

$\square$ Não

$\square$ Não sei

Lança a céu aberto

$\square \operatorname{sim}$

$\square$ Não

$\square$ Não sei

Joga no rio

$\square \operatorname{Sim}$

$\square$ Não

$\square$ Não sei

9.2 $O$ que a maioria das pessoas no assentamento fazem com o lixo ?

$\square$ Queima a céu aberto

$\square$ Joga no rio

Não sei

$\square$ Coleta pública

$\square$ Lança a céu aberto

Reciclagem

Compostagem

Enterra em vala

Utilização na lavoura (adubo)

\section{Conservação do solo}

\begin{tabular}{|c|c|c|c|c|c|c|c|c|}
\hline \multicolumn{6}{|c|}{ 10.1 Você sabe o que é erosão do solo ? } & \multicolumn{3}{|c|}{$\square \operatorname{Sim} \square$ Não } \\
\hline \multicolumn{6}{|c|}{ 10.2 No assentamento tem muita enxurrada que leva terra? } & $\square \operatorname{sim} \square$ & $\square$ Não & $\square$ Não sei \\
\hline \multicolumn{6}{|c|}{ 10.3 No seu lote tem muita enxurrada que leva terra embora (erosão)? } & $7 \operatorname{sim}$ & $\square$ Não & $\square$ Não sei \\
\hline \multicolumn{6}{|c|}{ 10.4 Conhece algum jeito de diminuir a erosão? } & $\mathrm{Sim}$ & $\square$ Não & $\square$ Não sei \\
\hline \multicolumn{9}{|c|}{ 10.5. Qual(is)? } \\
\hline \multicolumn{8}{|c|}{ 10.6 Quanto custa uma hora de trator para fazer terraços?. } & $\square$ Não sei \\
\hline \multicolumn{6}{|c|}{ 10.7 No assentamento alguém faz plantio direto? } & $\operatorname{Sim}$ & $\square$ Não & $\square$ Não sei \\
\hline \multicolumn{6}{|c|}{$\begin{array}{l}\text { 10.8 No assentamento alguém faz lavoura sem preparar (arar e gradear) } \\
\text { o solo? Planta na palha? }\end{array}$} & $\mathrm{Sim}$ & $\square$ Não & $\square$ Não sei \\
\hline \multicolumn{6}{|c|}{ 10.9 No assentamento alguém tem terraços (curva de nível)? } & Sim & $\square$ Não & $\square$ Não sei \\
\hline \multicolumn{6}{|c|}{10.10 No assentamento alguém tem a produção orgânica ? } & $\operatorname{Sim}$ & $\square$ Não & $\square$ Não sei \\
\hline \multirow[t]{2}{*}{ 10.11 Pega fogo na: } & \multicolumn{2}{|c|}{ Reserva } & \multicolumn{2}{|c|}{ Mata } & \multicolumn{2}{|r|}{ Pasto } & \multicolumn{2}{|r|}{ Roça } \\
\hline & Hoje & $\begin{array}{c}\text { Antes } \\
\text { ( ) anos atrás }\end{array}$ & Hoje & $\begin{array}{c}\text { Antes } \\
\text { ( ) anos atrás }\end{array}$ & Hoje & $\begin{array}{c}\text { Antes } \\
\text { ( ) anos atrás } \\
\end{array}$ & Hoje & $\begin{array}{c}\text { Antes } \\
\text { ( ) anos atrás }\end{array}$ \\
\hline \multicolumn{9}{|l|}{ Todo ano } \\
\hline \multicolumn{9}{|l|}{ Intervalo de 2 a 5 anos } \\
\hline \multicolumn{9}{|l|}{ Último fogo a mais de ( ) anos } \\
\hline Não tem & & & & & & & & \\
\hline
\end{tabular}




\section{Capacitação ambiental}

11.1 Já ouviu falar de / Tem alguma instituição (ex. ONGs, Universidades, Empresas) que trabalha com projetos/pesquisa no assentamento ?

$\square \operatorname{Sim}$ Qual:

$\square$ Não

Não sei

11.2 Já ouviu falar de / Tem algum projeto/estudo desenvolvido no assentamento relacionado com meio ambiente, educação ambiental ou proteção da natureza ?

$\square \operatorname{Sim}$ Qual: $\square \square$ Não $\quad \square$ Não sei

11.3 Você já fez algum curso/palestra sobre meio ambiente ou sobre a $\quad \square \operatorname{Sim}^{*} \quad \square$ Não $\square$ Não sei proteção da natureza.

Assunto

Quem organizou

* $\quad 1$.

* 2.

* 3 .

11.4 Gostaria de fazer (algum/outros) cursos/palestras ?

$\operatorname{Sim} *$

Não $\square$ Não sei

Assunto

* $\quad 1$.

* 2 .

* 3 .

11.5 Alguém que mora no lote já fez algum curso/palestra sobre o $\square \operatorname{Sim}^{*} \quad \square$ Não $\square$ Não sei meio ambiente ou sobre conservação da natureza.

Assunto

Quem organizou

* 1 .

* 2 .

* 3 .

11.6 Acha que outras pessoas do assentamento deveriam fazer ? $\square \operatorname{Sim}^{*} \quad \square$ Não $\square$ Não sei Assunto

* 1.

* 2.

* 3 . 


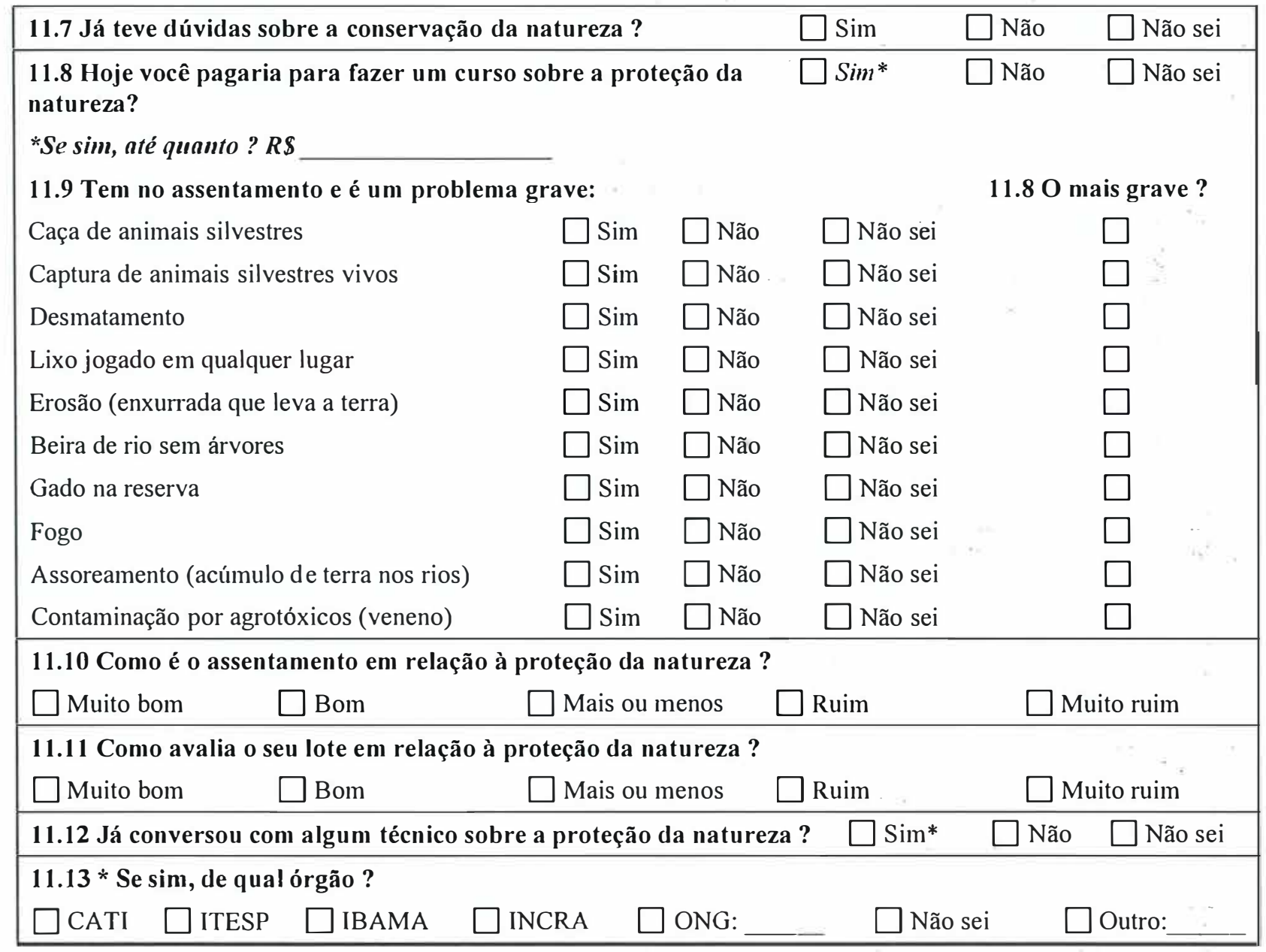


12. Reflorestamento

12.1 Já plantou floresta nativa? $\quad \square \operatorname{Sim}^{*} \quad \square N a o^{*} \quad \square$ Não sei

* (Exceto se responder "Não sei") Por que?

12.2 Já plantou floresta de eucalyptus ou pinos? $\quad \square \operatorname{Sim}^{*} \quad \square N a o^{*} \quad \square$ Não sei

* (Exceto se responder "Não sei") Para que (qual o uso das árvores)?

12.3 Deveriam plantar mais árvores no assentamento? $\quad \square \operatorname{Sim}^{*} \quad \square$ Não* $\square$ Não sei

* (Exceto se responder "Não sei") Por que?

12.4 Quantas mudas são usadas para se plantar um hectare de floresta nativa ?

mudas $\square$ Não sei $\square$ Outro:

12.5 Quanto tempo uma área plantada com árvores nativas deve receber tratos culturais tais como roçada, adubação, controle de formigas?

Não sei

12.6 Quanto custa uma muda de árvore nativa ?

12.7 Quanto custa uma muda de árvore exótica (eucalyptus, pinus) ?

Não sei

12.8 Onde consegue mudas de árvores nativas?

12.9 Onde consegue mudas de árvores exóticas? (eucalyptus, pinus) 
13. Meio ambiente

13.1 O que acha que deve ser feito para melhorar a natureza do assentamento?

13.2 O que acha que deve ser feito para melhorar a natureza do seu lote?

13.3 Quem mais se beneficia com a melhora a natureza do assentamento ?

$\square$ IBAMA/DPRN $\square$ ITESP $\square$ Pessoas da cidade $\square$ Assentados $\square$ Não sei

13.4 Já recebeu algum fiscal do meio ambiente (proteção da natureza) $\quad \square \operatorname{Sim}{ }^{*} \quad \square$ Não $\square$ Não sei *Se sim, de qual órgão? $\square$ ITESP $\square$ Polícia Florestal $\square$ DPRN $\square$ IBAMA $\square$ Não sei

13.5 Existem disponíveis fontes de dinheiro (linhas de crédito, subsídios, PRONAF) ou recursos (sementes, cursos, mudas, equipamentos, entre outros) para melhorar proteção da natureza?

$\square \operatorname{Sim}^{*} \quad \square$ Não $\square$ Não sei

*Se sim, quem fornece?

13.6 Já recebeu algum recurso ou dinheiro para melhorar a proteção da natureza ?

$\square \operatorname{Sim}^{*} \quad \square$ Não $\quad \square$ Não sei

*Se sim, quem forneceu o que?

13.7 Conhece alguém do assentamento que já recebeu recursos ou dinheiro para melhorar a proteção da natureza?

$\square \operatorname{Sim}^{*} \quad \square$ Não $\square$ Não sei

*Se sim, qual recurso?

14. Informações Finais

Horário de final (24h):

Lote vizinho de Reserva ou APP?

Foi um bom entrevistado?
M

$\square \operatorname{Sim} \square$ Não

$\square \operatorname{Sim} \square$ Não 
136

Observações finais:

\begin{tabular}{l}
$\longrightarrow$ \\
\hline
\end{tabular} 